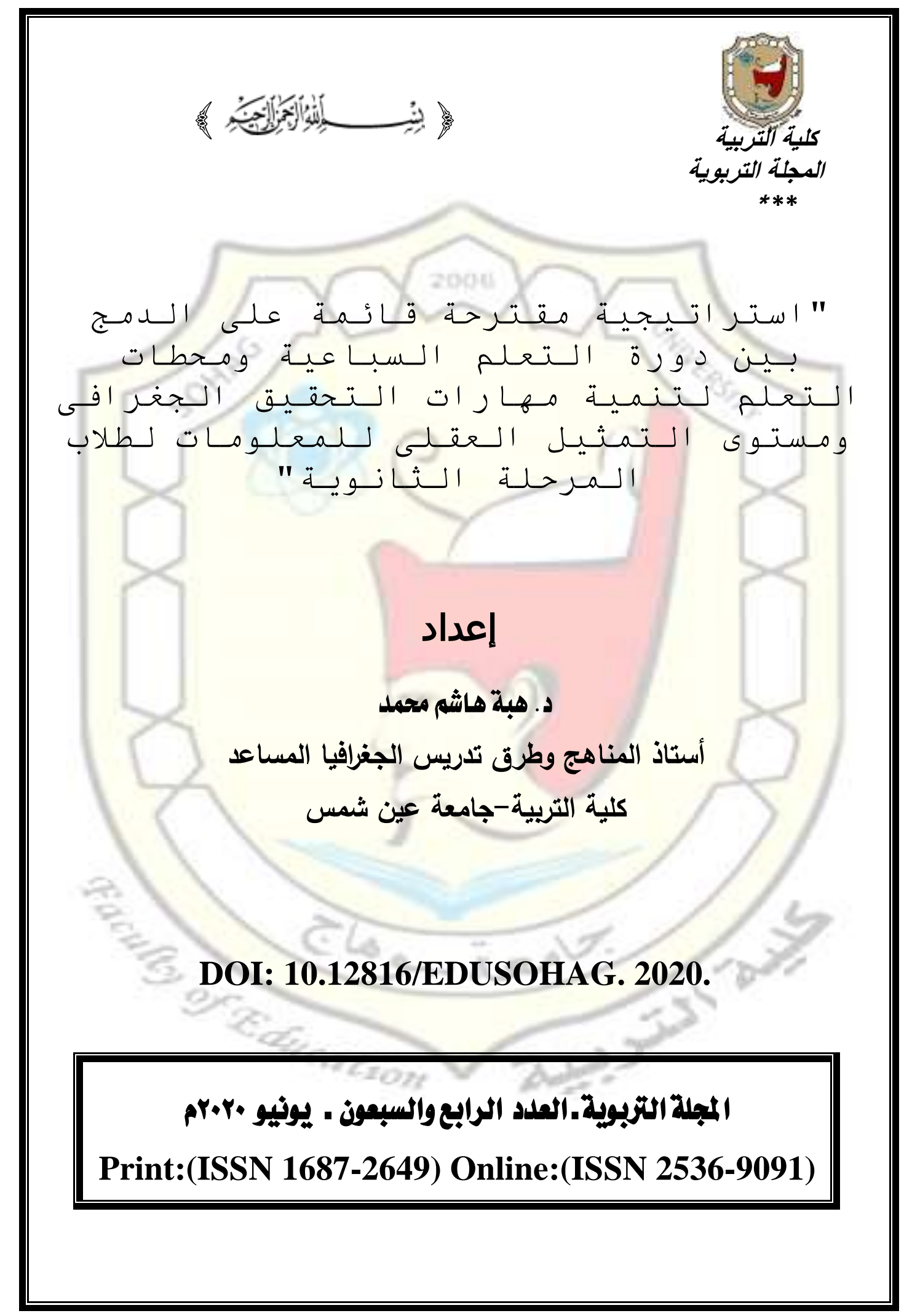




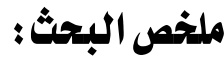

هاف البحث إلى قياس أثر استخدام استراتيجية مقترحة قائمة على الامجج بين دورة التعلم السباعية ومحطات التعلم لتنمية مهارات التحقيق الجغرافى ومستوى التمثيل العقلى للمعلومات لطلاب المرحلة الثانوية. واستخدم البحث المنهج الوصفى والتجريبى. وتمثلت أدوات البحث في قائمة بمهارات التحقيق الجغرافى ووحدة (الأنثطة الاقتصادية في مصر) معاد صياغتها ودليل للمعلم واختبار مهارات التحقيق الجغرافى ومقياس التمثيل العقلى التئي

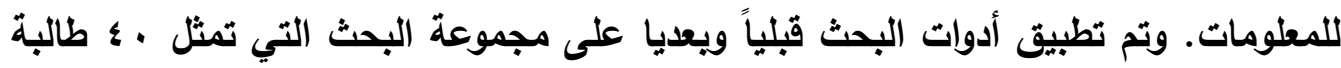
مجموعة ضابطة و. .؛ طالبة مجموعة تجريبية. وجاءت النتائج مؤكدة وجود فرق دال إحصائياً عند مستوى ا ...بين متوسطى درجات طلاب المجموعتين التجريبية والضابطة في التطبيق البعدي فى اختبار مهارات التحقيق الجغرافى والدرجة الكلية لصالح المجموعة التجريبية. كما يوجد فرق دال إحصائياً عند مستوى ال...بين متوسطى درجات طات طلاب المجموعتين التجريبية والضابطة في التطبيق البعدي فى مقياس التمثيل العقلى للمعلومات

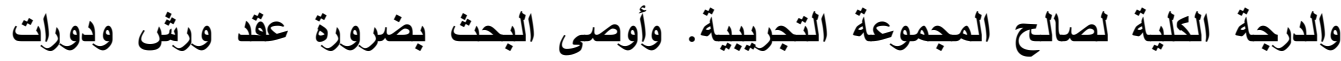
لتدريب المعلمين على كيفية الامج بين الاستراتيجيات التدريسية وكيفية تطبيقها داخل الفصول وخاصة تلك الاستراتيجيات القائمة على البنائية والخبرات السابقة للطلاب.

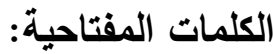

دورة التطم السباعية، محطات التعلم، مهارات التحقيق الجغرافى ومستوى التمثيل العقلى للمعلومات 
استراتيجية مقترحة قائمة على الدمج بين دورة التعلم السباعية ومحطات التعلم

A Suggested Strategy Based on Integration between $\underline{7 E^{\prime}}$

Learning Cycle and learning stations for developing the geographical investigation skills and the mental representation level of information of Secondary stage Students

\begin{abstract}
:
The research aimed to measure the effect of using a Suggested strategy based on Integration between 7E's Learning Cycle and learning stations for developing the geographical investigation skills and the mental representation level of information of Secondary stage Students. The research used descriptive and experimental approaches. The research tools included a list of geo-investigative skills, unit of (economic activities in Egypt) which was reformulated, a teacher's guide, test of geographical investigation skills, and the scale of mental representation of information. The research tools were pre and post applied of the research group consisting of 40 female students as a control group and 40 female students as an experimental group. The results confirmed that there is a statistically significant difference at level 0.01 between the average marks of the two control and experimental groups in the post application in the test of geographical investigation skills and the total mark was in favor of the experimental group. Also, there is a statistically significant difference at level 0.01 between average marks of the students of the two control and experimental groups in the post application in the scale of mental representation of information and the total mark was in favor of the experimental group. The research recommends the need for conducting workshops and courses to train teachers on how to integrate between the teaching strategies and how to apply then inside classes especially these strategies based on constructivism and previous experiences of the students.
\end{abstract}

key words: 7E's Learning Cycle, learning stations, the geographical investigation skills, the mental representation level of information 
أصبح تثخيص وتحديد المشاكل الحقيقية التي تواجه تدريس الجغرافيا، همَّا مشتركا بين بلدان عديدة، ليس في مصر فقط بل في العديد من الدول، إذ تظهر هذه الصعويات

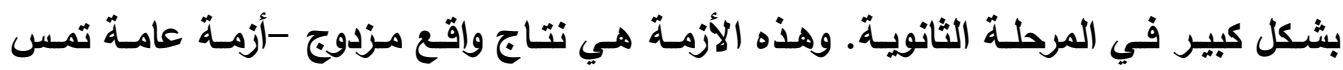
مختلف المواد الدراسية، وأخرى خاصة بالجغرافيا. وتتعدد الصعويات الأساسية التي تحدُّ من تطوير تجديد تدريس الجُغرافيـا، مثل هُوِيـة

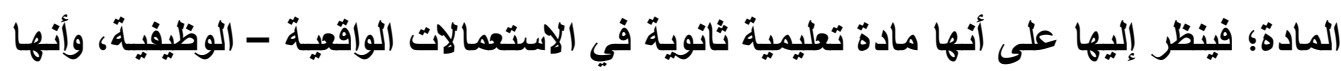

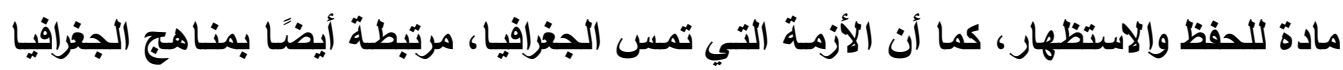

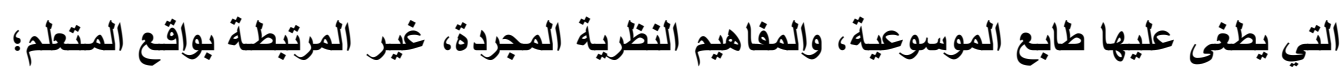
مما يجعله يعيش انفصاما تريويا بين النظري والواقع. ومن ثم هناك مجموعة من الأسئلة تطرح نفسها على تدريس الجغرافيا، منها:

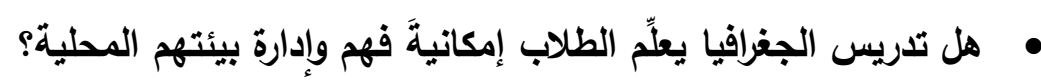
• هل تلدريس الجغرافيا يمكن الطلاب من التفكير في المشـاكل الكبرى التي يعيشـها عالم

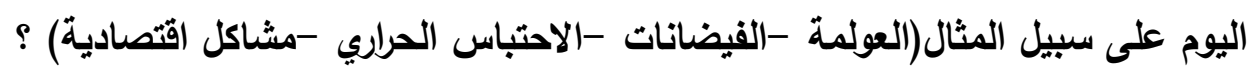
• هل المعرفة الجغرافية التي يحصل عليها الطلاب تساعدهم في الانفتاح العلمى وإلثقافى، وفتح الطرق أمامهم للحصول على معارف جديدة؟

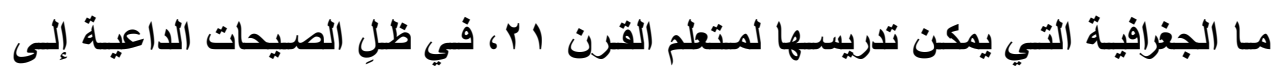

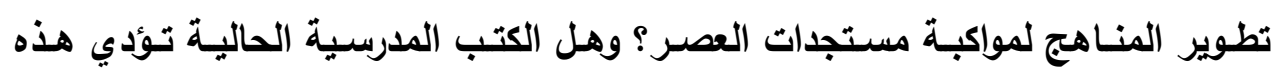
الوظيفة

وللإجابـة عن هذه الأسئلة لابــ مسن تغير نظرتــا إلـى تـدريس الجغرافيـا وضـرورة

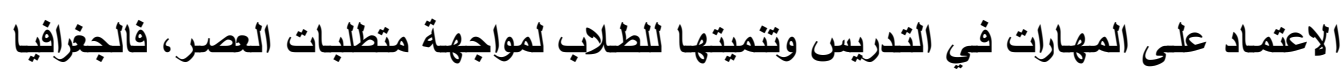
التي يحتاجها الطالب اليوم هي التي يمكن تطبيق مـا تم اكتسابه في الفصول الاراسية، وما يكتسبه من مهارات جغرافية هو الهدف الرئيس لتدريس الجغرافيا في المرحلة الثانوية مثل فئل جمع المعلومات وربط وتحليل الظواهر الجغرافية، وقياس تأثيرها على مناشط الحياة المختلفة. ويعد التحقيق الجغرافى أحد المهارات الهامـة التي يجب ان يتمكن منها الطلاب لما ونا في مجتمعنا من مشكلات اقتصادية واجتماعية وسياسية، تحتاج أن يفكر الطلاب تفكيراً علمياً 
قائم على التقصى والتحقيق لحل هذه المشكلات، ولكى تتم عملية التحقيق بنجاح لابد وأن يتقن الطلاب أدوات التحقيق الجغرافى ووظائفها وكيفية استخدامها. فالتحقيق الجغرافي عملية يتطم بها الطلاب ويعمقون فههمج للجغرافيا، فهي تتضمن تحقيقات فردية أو جماعية تبدأ بتحديد المشكلات والقضايا والموضوعات الجغرافية وتثرع في وني

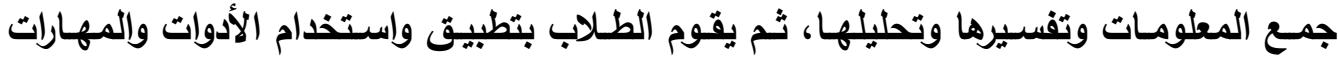

الجغرافية لوضع الاستتتاجات والمقترحات المختلفة، وعند الاقتضاء، التصرف بناء علئهاء

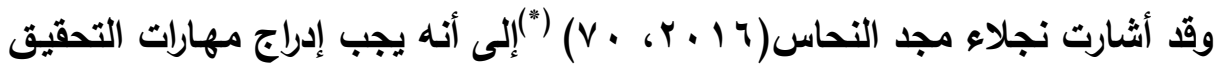
الجغرافى فى مناهج الجغرافيا، بحيث ينتقل الطلاب من وصف الظواهر إلى تحليلها وتفسيرها، من الملاحظة إلى التحقيق والتحليل واتخاذ القرار والتقييم والتفكير، من معرفة بسيطة لمعرفة أكثر تعقياً لعملية التحقيق الجغرافى، ومن استخدام عدد قليل من المفاهيم إلى عدد متزايد من المفاهيم، وفهم أعمق لها.

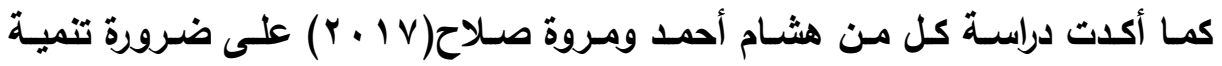
مهارات التحقيق الجغرافى للطلاب في جميع المراحل الدراسية، ولهذا فقد وضـع الباحثنان مهارات التحقيق الجغرافى كمعيار رئيسى من المعايير المقترحة في الروئية المستقبلية لمناهج الجغرافيا القومية في ضوء المعايير العالمية.

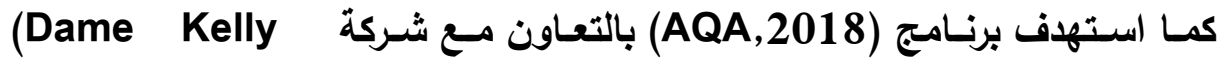
(Holmes Trust) الفصل الدراسس، ولهذا حدد البرنامج مجموعة من مهارات التحقيق الجغرافى التي يجب أن أنسات

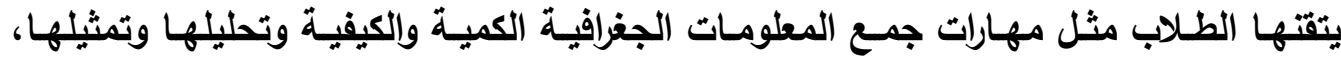
واستخام المهارات الإحصائية والتكنولوجية، واستخدام قواعد البيانات. ونظراً لأهمية مهارات التحقيق الجغرافى فقد نـادت العديد مـن الأدبيات والدراسـات

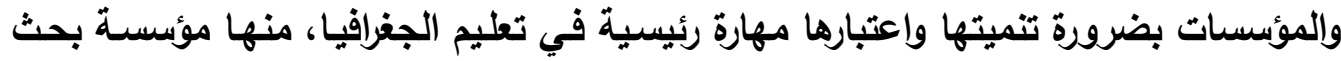

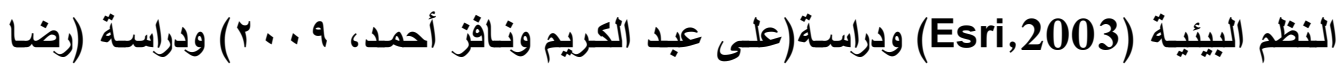

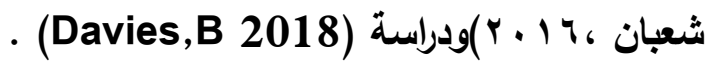
الصفحة). 
ولكى يتم اكتسـاب الطلاب مهارات التحقيق الجغرافى بكفاءة عاليـة لابد وأن يكون للديهم مستوى مرتفع من التمثيل العقلى للمعلومـات، وأن يكون هناك تتطابق بين التمثيلات المعرفية الداخلية وما يكتسبه الطلاب من معلومات وحقائق جغرافية عبر الحواس المختلفة.

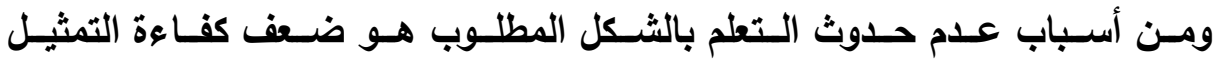

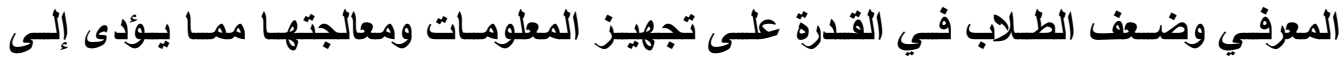

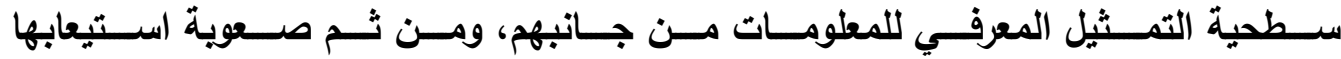

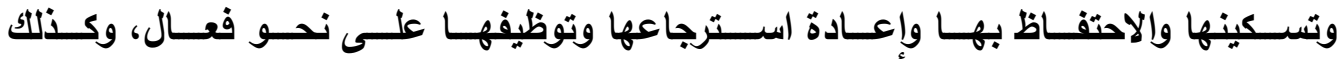
صعوية استخلاص العلاقات بين المعلومات الجديدة والسابقة.

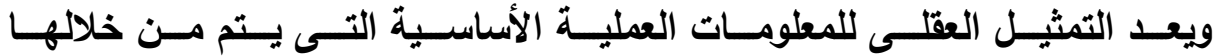

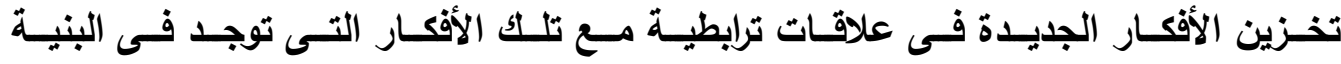

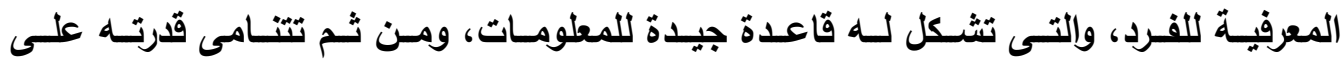

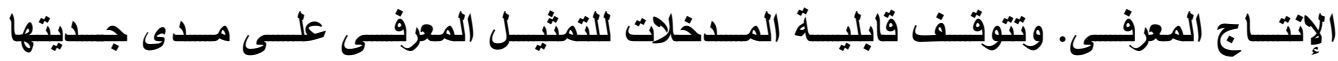

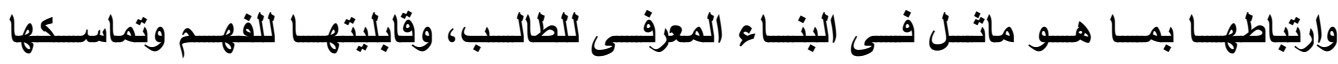
وتكاملهـا وارتباطهـا ببعضـها الـعض، وقابليتهـا للتصـنيف أو التمييـز، وارتباطهـا بـالواقع

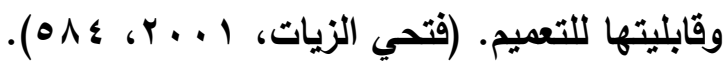
وقد أكدت دراسـة (على صكر، 9 ، . ب) ضـرورة تضمين المنـاهج الدراسية أنشطة واستراتيجيات تعتمد على محتوى معرفي مترابط ومتمايز ليسهل تنظيمه من الطلبة بمـا يضمن

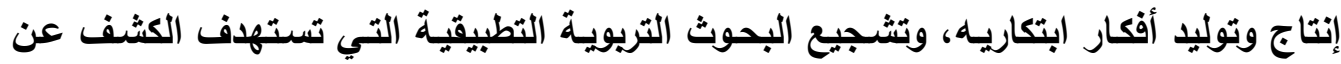
سبل تنميته وكفاءة التمثيل المعرفي للمعلومات. ونظراً لأهمية تنمية مستوى التمثيل العقلى للمعلومات فقد استخدمت دراسـة (نسرين

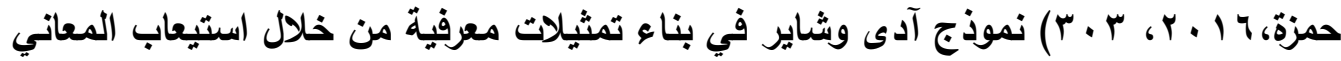
والافكار ليتم الاحتفاظ بها لتصبح جزءً من البنية المعرفية. وأظهرت النتائج أثراً ايجابياً لنموذج (آدي وشاير) في التحصيل والتمثيل المعرفي لاى طالبات الصف الخامس العلمي في 
كما هدفت دراسة (جمانة خزام، Y V + Y إلى تعرف مستوى كفاءة التمثيل المعرفي للمطلومات لاى طلبة الصف الأول الثانوي العام في مدينة حمص، وأوصت الدراسـة بضرورة إثراء المناهج بالمزيد من أثكال التمثيل المعرفي للمعلومات (الرسوم البيانية، الصور، الخرائط المفاهيمية، الجداول، المخططات بأثنكالها).

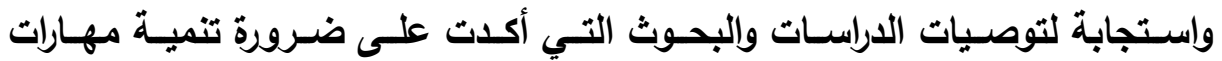
التحقيق الجغرافى وزيادة مستوى التمثيل العقلى للمعلومات لاى الطلاب فكان لابد من التوجها إلى نظريات واستراتيجيات من شأنها تنمية هذه المهارات ومن هذه النظريات النظرية البنائية، وقد حظيت باهتمـام واسـع؛ نظرًا لمـا قدمتهـه من أفكار وتطبيقات حولت التركيز من العوامـل الخارجية المؤثرة في التعليم إلى العوامل الداخلية، وما يحدث داخل عقل المتعلم أثناء المواقف هئف التعليمية كمعرفته السابقة، وكيفية معالجة المعلومات، والأسـاليب التي تجعل التعليم ذا معنى بالنسبة له، عندما تتفاعل المعلومات الجديدة مع خبراته السـابقة، لتكوين بنية معرفية جديدة أكثر تمايزًا بطريقة تضفي على الخبرات الجديدة معنى واضحًا ومميزًا مما يؤدى إلى تثبيتها. وتعد دورة التعلم السباعية ومحطـات التعلم أحد أهم التطبيقات التي انبثقت مسن النظريـة البنائيـة، التي تدعو إلى رفع المستويات المعرفية للطلاب، وتنميـة مهارات التفكير لديهم وزيادة قدرتهم على بناء تمثيلات عقلية ذات معنى، وزيادة دافعية الطلاب وقدرتهم على اتخاذ القرارات المهمة وتنمية مفهوم الأات لايهم. وترجيع أهمية استخدام دورة التعلم السباعية لأنها تثير فضول المتعلمين للمعرفة، وإثارة الأسئلة واللجوء إلى اكتشـاف العلاقات والمفاهيم والتراكيب المعرفية المختلفة، وتركز على تفسير وتحليـل المكونـات المعرفيـة. كمـا تهتم بتوسيع دائـرة التعلم مسن خـلال اجـراء تطبيقات جليدة على مواقف تعليمية متعددة، واستخدام ما للى المتعلمين من معرفة لاقتراح حلول وصياغة قرارات وتصميم تجارب وتسجيل ملاحظات وكتابة تقارير حول مـا توصلوا إليه من استنتاجات وتفسيرات. ونظراً لأهمية دورة التعلم السباعية فقد أثارت العديد من الدراسات إلى ضرورة Sirbunnam \& Tayraukham, توظيفها في العملية التدريسية مثل دراسة كل من من التمنية

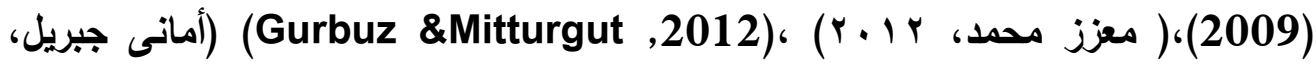




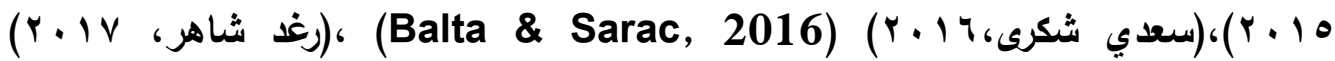

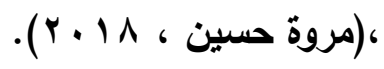

وتعد استراتيجية محطات التعلم أحد أثكال التنوع لأساليب وطرق التدريس والأنشطة التعليمية حيث يتحول فيها شكل الفصل من الثكل التقليدي إلى بعض الطاولات التي يطوف حولها الطلاب وفقًا لنظام محدد، كل طاولة تمثل محطة تعليمية مزودة بمواد تعليمية وأورلق

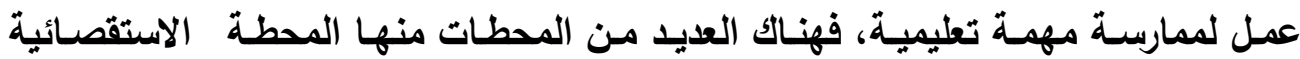
الاستكثافية، المحطة القرائية، المحطة الصُورية، المحطة السمعية البصرية، المحطة الإكترونية، المحطة الاستثارية، محطة متحف الثمع، ومحطة الـ (نعم) والـ (لا). وقد أثثارت العديد من الدراسات إلى فاعليتها فى تحقيق العديد من الأهداف التعليمية مثل دراسة (حنان مصطفى، ب 1 ـ r) التى استخدمتها لتنمية عمليات العلم والتفكير الإبداعي والدافعيـة نحو التعلم. ودراسـة (David \&Chamber,2013) التي استخدمتها في تنمية

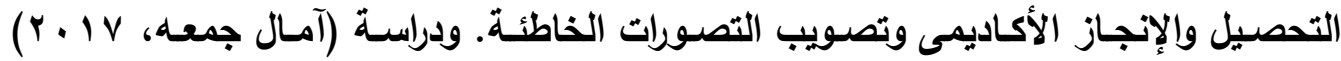
التي نمت بها التفكير الاستـلالى والتسـامـح الاجتماعى للدى طلاب المرحلة الثانويـة. ودراسـة (التي اهتمت بتنمية المفاهيم التكنولوجية واتخـاذ القرار. Aqel\& Haboush, 2017) ودراسة (Chien, 2017) التي اهتمت بتنمية الاتجاهات الإيجابية للطلاب المعلمين لتنفيذ

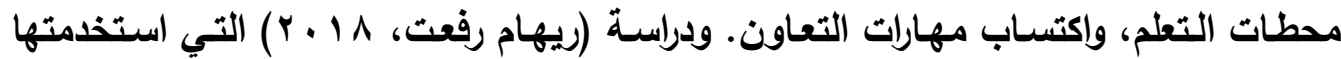
لاستكشاف النماذج العقلية للبيئة وتطويرها لدى طالبات الصف الأول الثانوي. ممـا سـبق يتضـح مـدى أهميـة تنميـة مهـارات التحقيتق الجغرافي ومسـتوى التمثيـل العقلى للمعلومات لطلاب المرحلة الثانويـة ومدى الاهتمام بهم كمتطلبات رئيسية للتعليم في الوقت الحسالي وللمستقبل، ويسالرغم مـن ذلك نجد أن الواقع يشير إلـى أن المعلمـون مـازالوا يعتمدوا على الطرق التقليدية، الأمر الذى انعكس على الطلاب في عدم قدرتهم على تقبل مـادة الجغرافيا وعزوفهم عن دراستها. ولهذا جاء هذا البحث في محاولة لتقديم استراتيجية

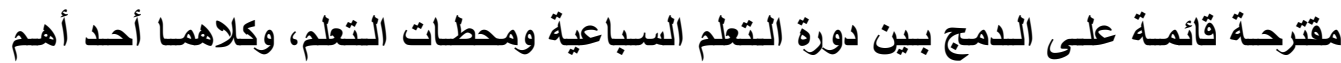
تطبيقات النظرية البنائية. 
مشكلة البحث: - ماث

تحددت مشكلة البحث في ضعف مهارات التحقيق الجغرافى وإنفاض مستوى التمثيل العقلى للمعلومـات لطلاب الصف الأول الثانوى، وتمثلت مشكلة البحث في السؤال الرئيس التالى

مـا الاستراتيجية المقترحة القائمسة على اللدمج بين دورة التعلم السباعية ومحطات

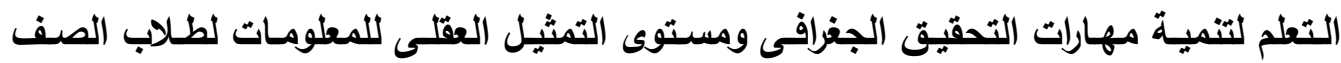
الأول الثانوى؟ - n

وتفرع من السؤال الرئيس الأسئلة التالية:

ما مهارات التحقيق الجغرافى الواجب تنميتها لطلاب الصف الأول الثانوى؟ ما أسس بناء استراتيجية مقترحة قائمة على الدمج بين دورة التعلم السباعية ومحطات التعلم لتنمية مهارات التحقيق الجغرافى ومستوى التمثيل العقلى للمعلومات لطلاب الصف دلف دورة الأول الثانوى؟ ما صورة وحدة معاد صياغتها في ضوء الاستراتيجية المقترحة القائمسة على الدمج بين

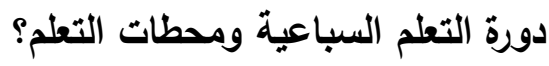
ما أثر الاستراتيجية المقترحة في تنمية مهارات التحقيق الجغرافى لطلاب الصف الأول الثانوى؟ ما أثر الاستراتيجية المقترحة في تتمية مستوى التمثيل العقلى للمعلومـات لطلاب الصف

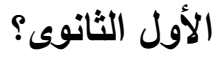

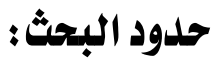
مجموعة من طالبات الصف الأول الثانوى بمدرسة شبين القناطر الثانوية بنات.

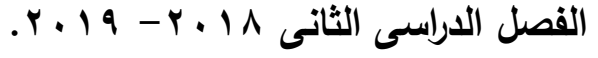
اختيار وحدة (الأنشطة الاقتصادية في مصر) من مقرر الجغرافيا للصف الأول الثانوى للأسباب التالية/ تبـنغ نسبة الوحدة ( • ؛ \%) من مقرر الجغرافيـا للصف الأول الثانوى، ومـن ثم تصبح

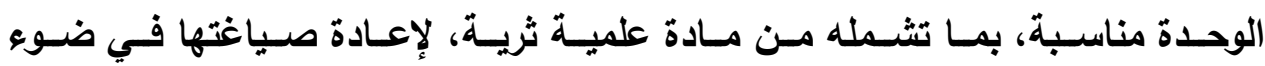
الاستراتيجية المقترحة القائمة على الدمج بين دورة التعلم السباعية ومحطات التعلم. 
口 طبيعة محتوى الوحدة يمكن من خلاله تنمية مهارات التحقيق الجغرافى. 口 تحتوى الوحدة على العديد من الصور والأثثكال والعروض التوضيحية يمكن من خلالها هنهات رفع مستوى التمثيل العقلى للمعلومات.

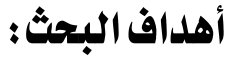

تحديد أثز استخدام استراتيجية مقترحة قائمسة على الدمج بين دورة التعلم السباعية ومحطـات التعلم على تنميـة مهارات التحقيق الجغرافى ومستوى التمثيل العقلى للمعلومـات لطلاب الصف الأول الثانوى. أهمية البحثث: ترجع أهمية البحث في تقديم: • قائمة بمهارات التحقيق الجغرافى الواجب تنميتها لطلاب الصف الأول الثانوى. وحدة معاد صياغتها باستخدام الاستراتيجية المقترحة القائمة على الامج بين دورة التعلم السباعية ومحطات التعلم لظلاب الصف الأول الثانوى. • دليل للمعلم يوضح كيفية تدريس وحدة (الأنشطة الاقتصادية في مصر) باستخدام استراتيجية مقترحة. • اختبار مهارات التحقيق الجغرافى الواجب تنميتها لطلاب الصف الأول الثانوى. • مقياس مستوى التمثيل العقلى للمعلومات لطلاب الصف الأول الثانوى. مصطاحات البحث: الاستراتيجية المقترحة: تم تعريفها إجرائياً بأنها: مجموعة مـن الخطوات الإجرائية

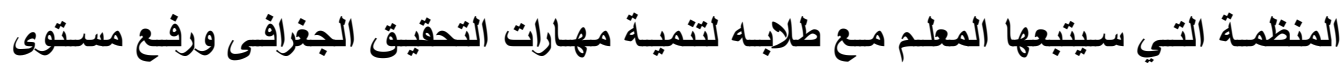
التمثيل العقلى للمعلومات للى طلاب الصف الأول الثانوى، وتتمثل هذه المراحل فى (مرحلة

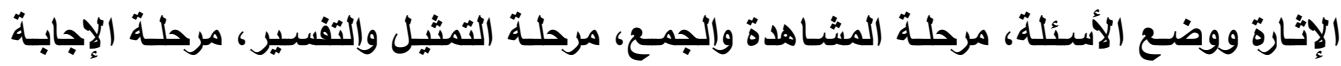
والتحقق، مرحلة التقويم والتأمل). دورة التعلم السباعية: تعرف إجرائياً بأنها: استراتيجية تدريسية بنائيسة تعتمد على ملى

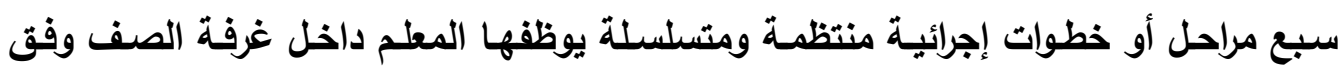

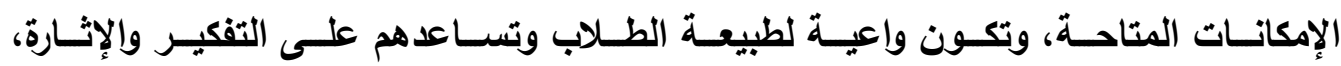


والاستكشاف، والتفسير، والتوسع، والتمديد، والتبادل، والفحص وذلك لتنمية مهارات التحقيق الجغرافى ورفع مستوى التمثيل العقلى للمعلومات.

محطات التعلم: وتُعرف إجرائياً بأنها: استراتيجية تدريسية تتمثل في مجموعة من المحطات يقوم الطلاب بالمرور عليها وممارسة الأنشطة التعليمية الموجودة بكل منها، والتي

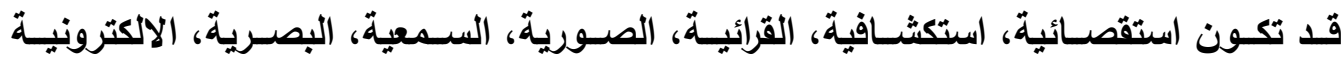
والاستثارية، لزيادة نشاط المتعلم وفاعليته في العملية التعليمية. التحقيق الجغرافى: تـم تعريفهـا إجرائيـاً بأنهـا: هـو مجموعـة مـن العمليـات العقليـة والأدائية التي يقوم بها الطلاب متبعين مجموعة من الخطوات المحددة تبأ بتحديد الهدف من من التحقيق الجغرافـى ووضـع أسـئلته، وجمـع وتسـجيل وتقيـيم المعلومـات، وتمثيلها وتفسيرها، والإجابة عن أسئلة التحقيق الجغرافى، والتفكير في النتائج التي توصل إليها التحقيق، وذلك بهدف وصول الطلاب للمعرفة الجغرافية الجديدة بأنفسهم وربطها بخبراتهم السابقة. التمثيل العقلى للمعلومات: تم تعريفها إجرائياً بأنها:

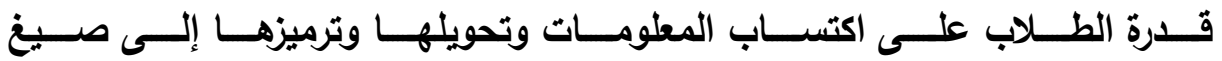

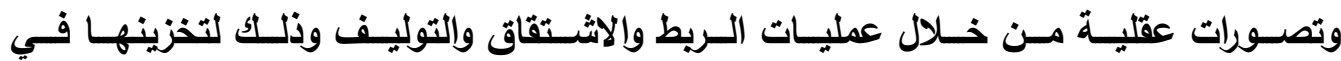
الأكرة طويلة المدى واسترجعها عند الحاجة. فروض البحث

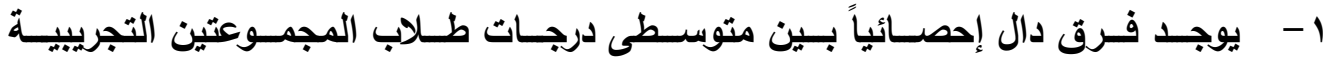
والضـابطة فـي التطبيـق البعـدي فـى اختبـار مهــارات التحقيـق الجغرافـى واللارجـة الكلية لصالح المجموعة التجريبية.

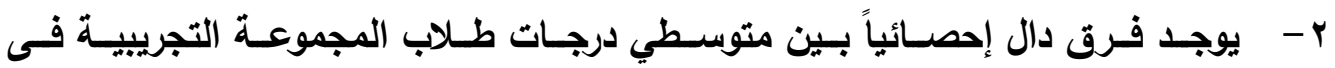

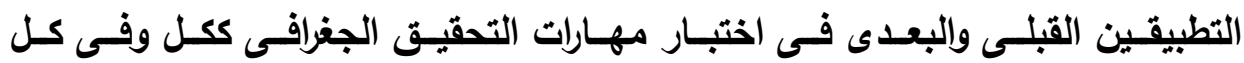
مهارة على حده وذلك لصالح التطبيق البعدى.

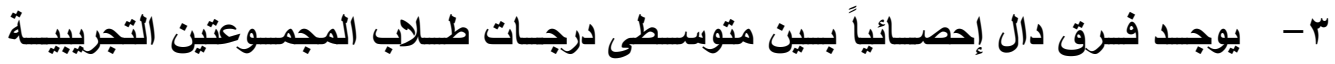
والضـابطة فـي التطبيـق البعـدي فـى مقيـاس التمثيـل العقلـى للمعلومــات واللدرجـة الكلية لصالح المجموعة التجريبية. 
ع - يوجد فرق دال إحصائياً بين متوسطى درجات طلاب المجموعة التجريبية في التطبيقين القبلي والبعدي لمقياس التمثيل العقلى للمعلومـات ككل وفى كل بعد على حده وذلك دئك لصالح القياس البعدى.

\section{منهج البحث:}

تم إجراء البحث وفقًا للمنهجين التاليين: • المنهج الوصفي: استخدم في إعداد الإطار النظري للبحث وفي إعداد أدوات البحث وتحليل النتائج وتفسيرها وتقديم التوصيات والمقترحات. • المنهج شبه التجريبي: وذلك في تجريب الاستراتيجية المقترحة على مجموعة البحث، وقياس فاعليتها من خلال اختبار مهارات التحقيق الجغرافى ومقياس التمثيل العقلى للمعلومات. اجراءوات البحث:

لتحقيق أهداف البحث وللتحقق من صحة الفروض تم اتباع الخطوات التالية:

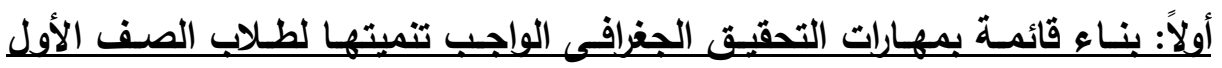
الثانوى وتم ذلك من خلال: ا ـ مراجعة الأدبيات واللاراسات التي اهتمت بالتحقيق الجغرافى ويمهاراته. r. ب. دراسة طبيعة مادة الجغرافيا، وخصائص طلاب المرحلة الثانوية. r. بناء قائمة مبائية بمهارات التحقيق الجغرافى وعرضها على السـادة المحكمين وضبطها وحها ووضعها في صورتها النهائية.

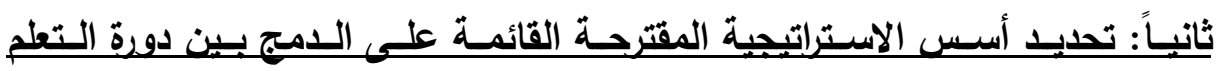
السباعية ومحطات التعلم ا ـ مراجعة الأدبيات والدراسات السابقة التي اهتمت بدورة التعلم السباعية ومحطات التعلم. r. تحديد الهرف من الاستراتيجة المقترحة. r. تحديد القلسفة القائمة عليها الاستراتيجة المقترحة. ؛ . تحديا مبادئ الاستراتيجية المقترحة. ه. تحديد مراحل الاستراتيجة المقترحة. צ. تحديد دور المعلم والمتعلم في تتفيذ الاستراتيجية المقترحة. 


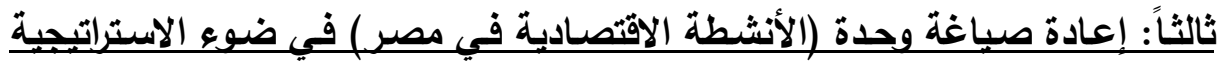

المقترحة التي تم التوصل إليها وتم ذلك من خلال:

1. تحديد الأهداف العامة والإجرائية للوحدة.

r r r تحديد الأنشطة والوسائل التعليمية المناسبة لتدريس الوحدة.

r. ب. تحديد أساليب تقويم الوحدة.

؛. اعداد دليل المطلم لتدريس الوحدة المعاد صياغتها.

ه. عرض الوحدة المعاد صياغتها ودليل المعلم على السـادة المحكمين لضبطها ووضعها

في صورتها النهائية.

رلبعاً: قياس أثثر الاستراتيجية المقترحة في تنمبة مهاريات التحقيق الجغرافيى ومستوى التمثيل العقلى للمعلومات، وتم ذلك من خلال:

1. إعداد اختبـار مهارات التحقيـق الجغرافـى لطـلاب الصـف الأول الثـانوى والتأكدـ مـن

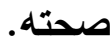

r. إعداد مقيـاس التمثيل العقلى للمطلومــات لطـلاب الصـف الأول الثـانوى والتأكد مـن

صحته.

r. اختيار مجموعة من طلاب الصف الأول الثانوى وتقسيمهم مجموعتين إحداهما ضابطة

$$
\text { والأخرى تجريبية. }
$$

؛. التطبيـق القبلى لاختبـار مهـارات التحقيـق الجغرافـى ومقيـاس التمثيـل العقلـى على لجى

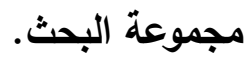

ه. تدريس الوحدة المعاد صياغتها للمجموعة التجريبية.

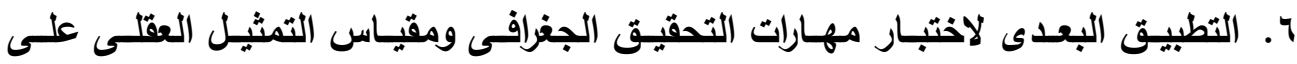

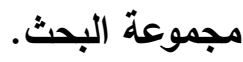

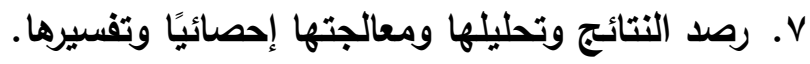
خامساً: تقديم التوصيات وإلمقترحات. 
الإطار النظرى للبحث

لما كان الهـف من البحث هو تحديد أثر استخدام استراتيجية مقترحة قائمـة على الامجج بين دورة التعلم السباعية ومحطات التعلم فى تنمية مهارات التحقيق الجغرافى ومستوى مئو

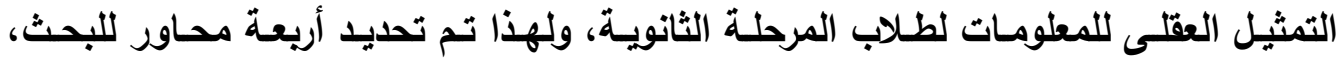
تمثلت في: المحور الأول عن (دورة التعلم السباعية). المحور الثانى وضح (محطات التعلم). المحور الثالث عن(التحقيق الجغرافى). والمحور الرابع تحدث عن(التمثيل العقلى للمعلومـات). وتم تناول هذه المحاور بالتفصيل. المحور الأول: دورة التعلم السبـية:Seven E's (تصريفها -مبادئها -مراحلها -أهميتها في

\section{تلدريس الجفرافيا ).}

تعد البنائية أحد أهم النظريات التي لها هدف مشترك وهو بنـاء المعرفة لدى الطالب من خلال خبراته السابقة، وريطها بالخبرات الحقيقية التي تواجهه في حياته، ويالتالي يصبح للتعلم معنى. وقد انبثق منها العديد من التطبيقات، منها دورة التعلم. وقد بدعت دورة التعلم بثلاث مراحل هي (استكثـاف، تفسير، وتطبيق المفهوم) على يـ Atkin and Karplus)، ثم تم تعديلها إلى أربع مراحل وتم إضـافة التقويم للمراحل

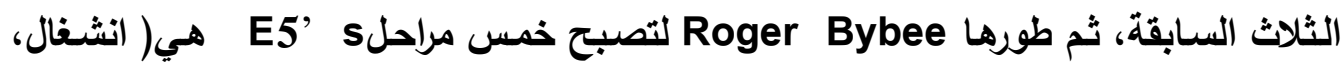
Seven E's استكشاف، تفسير، توسيع، تقويم) ثم تطورت دورة التعلم لتصبح سبع مراحل

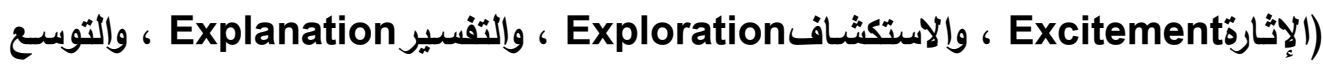

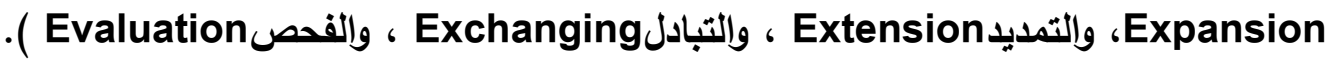
من ثم تعد دورة التعلم السباعيةS'Seven E's تطبيقا تريوياً وترجمة لبعض أفكار

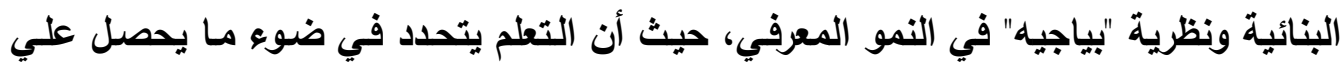

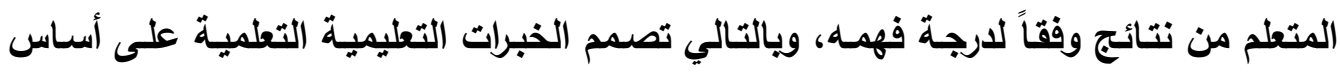
الوظائف المعرفيـة الثنلاث (التمثيل والمواعمـة، والتتظيم) ليصل المتعلم إلى درجـة عاليـة من التكيف والفهم العميق للمعلومات. 
تعريف دورة التعلم السباعية ؛

اختلفت تعريفات دورة التعلم السباعية Seven E's فالبعض قدمها على أنها نموذج

تعليمى والبعض الآخر قدمها على أنها استراتيجية تدريسية، وهنـاك من قدمها على أنها نموذج بنائى، ومن هذه التعريفات:

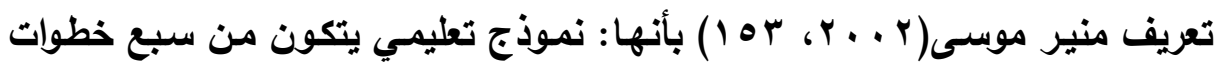

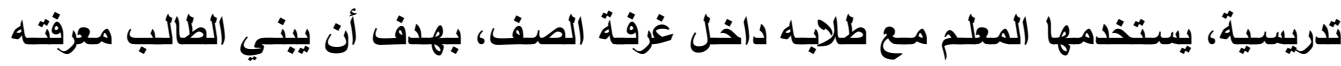

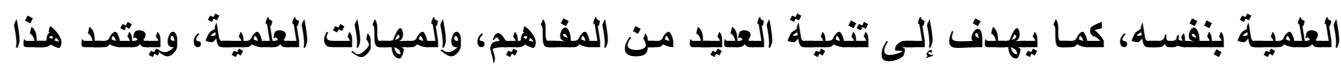
النموذج على الإثارة، وحب الاستطلاع، والفضول، والاستكثاف، والتقسير، والتوسيع، وريط المفاهيم بعضها ببعض، وتعديل بعض المفاهيم الخاطئة لايهم وتقويمها.

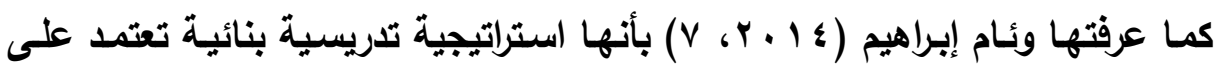
سبع مراحل، أو خطوات إجرائية منتظمـة ومتسلسلة يوظفها المعلم داخل غرفة الصف وفق لإنق الإمكانـات المتاحـة، وتكون شـاملة، ومراعيـة لطبيعة الطالب، بحيث تسـاعدهم على التفكير، ويناء التراكيب المعرفية، بأنفسـهم لتنمية مهارات التواصل، والاحتفاظ بها، وتبدأ أسماء كل مرحلة بالحرف Esen E,s) ، وهي: الإثارة، و الاستكشاف، و التفسير، و التوسيع، و التمديد، و التبادل، و الفحص.

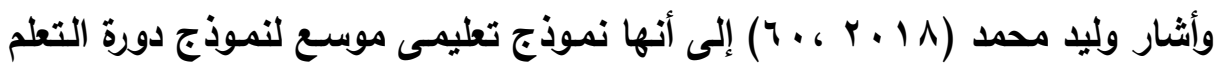
الخماسي يهاف إلى مساعدة المتعلم على تثكيل المعرفة والمفاهيم الجديدة بناء على معرفته وخبراته السابقة، وتنمية مهارات التفكير المنظومى ونقل التعلم في مواقف جديدة، وذلك من خـلال سبع مراحل رئيسية هـي (الإثـارة والاستكشـف والتفسير والتوسيع والتمديــ والتبـادل والفحص).

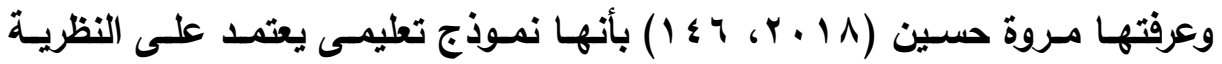

البنائية لـ(بياجية) ويتكون من خطوات تعليمية-تعلميـة يتم من خلالها بناء محتوى وحدة

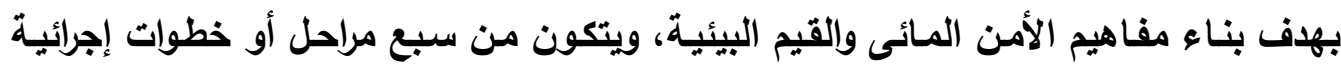
متسلسة ومنظمة يوظقها المعلم داخل الفصل الدراسى، والمراحل السبع تبدأ بحرف (E). 
ويقصد بها في البحث الحالي "استراتيجية تدريسية بنائية تعتمد على سبع مراحل أو

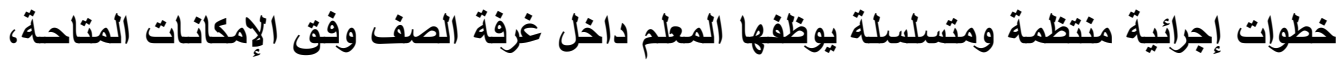
وتكون واعيـة لطبيعة الطـلاب وتسـاعدهم على التفكير والإثـارة، والاستكشـاف، والتفسير، والتوسع، والتمديد، والتبادل، والفحص وذلك التنمية مهارات التحقيق الجغرافى ورفع مستوى التمثيل العقلى للمطلومات. مبادئ دورة التعلم السباعية تتضمن استراتيجية Seven E,s عداً من المبادئ أو القواعد التي يجب على المعلم

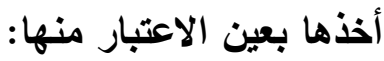
1 ا. أن يولي المعلم اهتماماً كبيراً بعملية التعليم، وذلك بأن تكون الخبرات المقصود تعليمها

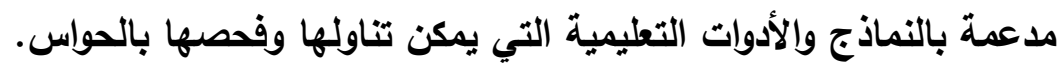

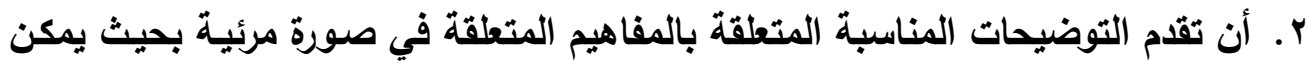
لجميع الطلاب إدراكها ويلوغ الغاية من تعلمها بسهولة.

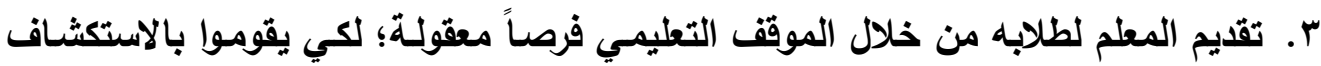

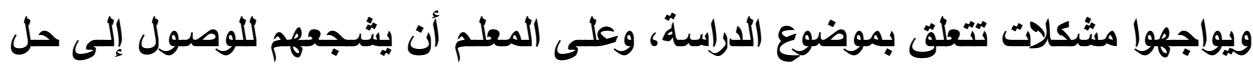
لها مستخدماً في ذلك مواد تعليمية واقعية قدر الإمكان.

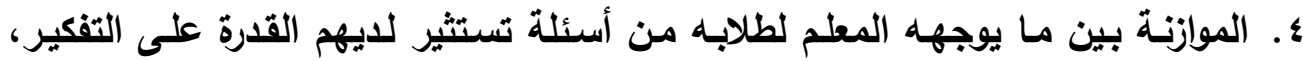
وأخرى تستثير قرتهج على التطبيق والتحليل، وثالثة تستثير قرترهم على التقويم.

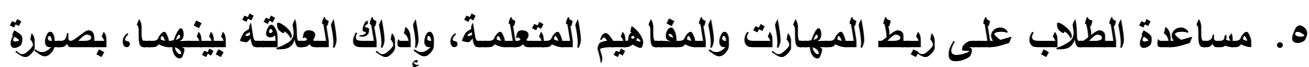
تعمل على تكامل ما لايهه من معارف سابقة، وما اكتسبوه من معلومات جديدة.

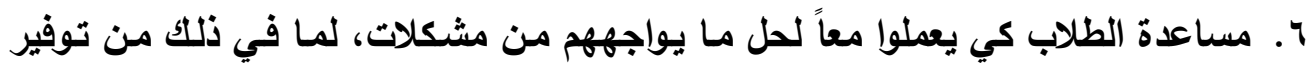

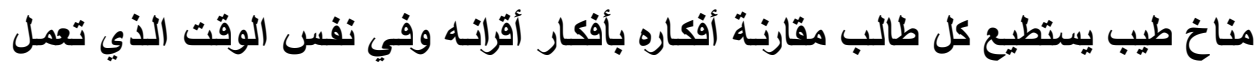

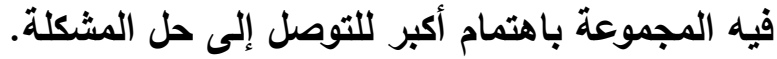

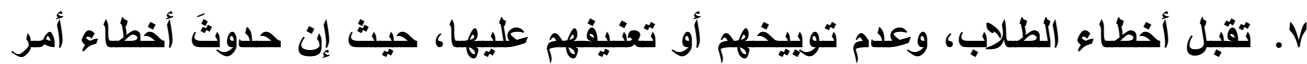

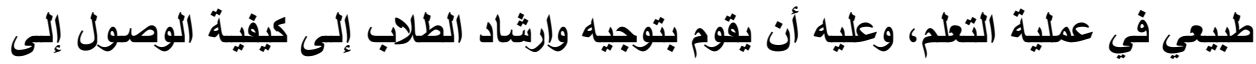
الإجابة الصحيحة لتصحيحها بأنفسهر. 
1. توجيه الطلاب إلى تطبيق مـا تعلموه داخل المدرسـة من خبرات جديدة في حياتهم

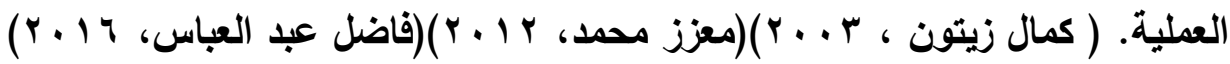

Seven E's مراحل دور التعلم السبياعية.

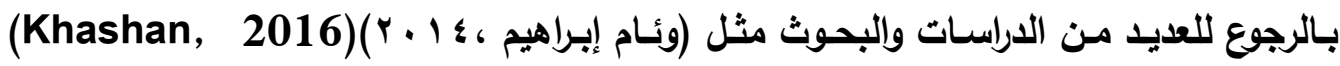

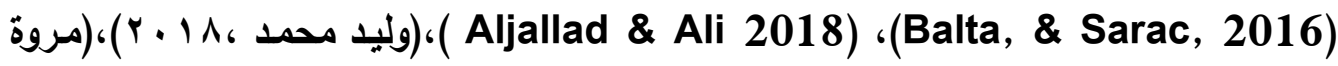

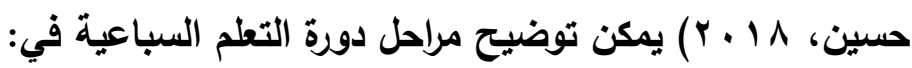

\section{أ. مرحلة الإثارة Excitement:}

وتهذف هذه المرحلة إلى الكثف عن الخبرات السـابقة للى الطلاب، وإثارة اهتمـامهم

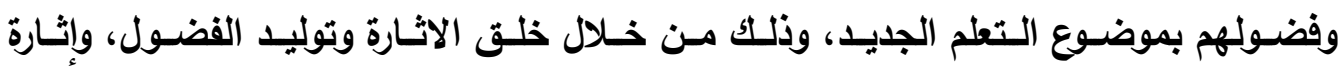

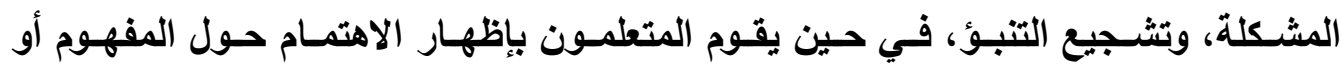
الموضوع عن طريق التساؤل الأتي.

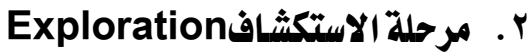

وتهوف هذه المرحلة إلى إرضاء الفضول، وحب الاستطلاع لاى الطلبة عن طريق توفير الخبرات والتعاون فيما بينهم، واستيعاب معنى المفهوم، من خلال اقتراح أنشطة تعليمية

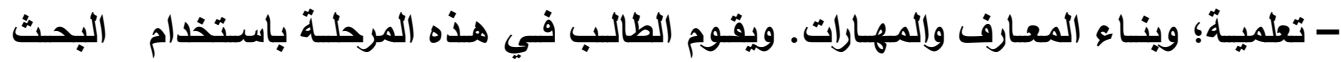
والاستقصاء، والتقكير بحرية في حدود النشاط الذي يقومون به.

\section{r. مرحلة التفسير Explanation}

تهدف هذه المرحلة إلى توضيح وشرح المفهوم المراد تعلمـه، وتعريف المصطلحات، وتوضيح المعارف والمهارات المراد تعلمها، وتعريفها إجرائياً من خلال الأنشطة المقدمة للطلاب في مرحلة الاستكشاف ويتحدد دور المتعلم في استخدام مصادر متتوعة للمعلومات وعمل المناقثات الجماعية وإلتفاعل مع المعلم.

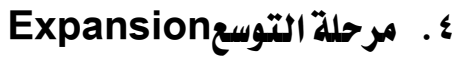

وتهدف هذه المرحلة إلى اكتشـاف تطبيقات جليدة للمفهوم أو المعارف، والمهارات التي تم بناؤها وتفسيرها من قبل الطلبة؛ وذلك لربطها بالمشكلات الحقيقية التي تواجههم في حياتهم الواقعية. وفيها يقوم المعلم بتثجيع الطلاب لتطبيق المفاهيم المهارات التي تم بناؤهـا في مواقف جديدة أو مواقف واقعية . 


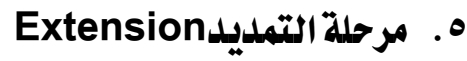

تهدف هذه المرحلة إلى توضيح العلاقة بين المفهوم والمفاهيم الأخرى، وفيها يتم تمديد المفهوم إلى موضوعات جديدة في مواد دراسية أخرى، ويكون دور المعلم ملاحظة الطلاب في تطبيق المفاهيم والمهارات الجديدة في مواقف حياتية جديدة.

\section{צxchanging}

تهرف هذه المرحلة إلى تبادل الأفكار والمهارات بين الطلاب من خلال قيامهم بعرض البيانات والرسـوم البيانيـة والأمثلة وغيرهـا مـن طرق عرض المهاده المعلومـات التي قاموا بجمعها ودراستها وعرضها على زملائهم. ويكون دور المعلم هو تقييم مشاركة جميع الطلاب في تبادل الأفكار والمعلومات.

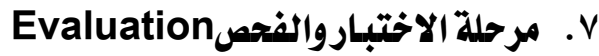

تهذف هذه المرحلة إلى تقييم تعلم فهم الطلاب للمفاهيم التي تم تعلمها، وإلمهارات والمعارف التي اكتسبوها، وتتميز هذه المرحلة بأنها متذاخلة مـع باقي المراحل، ومرافقة لكل مرحلة؛ وذلك للتأكد مـن تتفيذ خطوات كل مرحلـة بالشكل المناسب، وقيـاس مدى استفادة الطلاب بعد كل مرحلة، وتقديم التغذية الراجعة المناسبة وفي الوقت المناسب.

\section{أهمية دورة التعلم السباعية في تلدريس الجغرافيا} تتحدد أهمية دورة التعلم السباعية في تلديس الجغرافيا في:

توسيع دائرة التعلم من خلال إجراء تطبيقات جديدة على مواقف تعليمية متعددة.

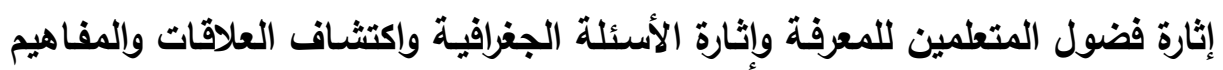
والتراكيب المعرفية الجديدة. تنمية مهارات البحث والاستقصاء الجغرافى لتحقيق وإرضاء فضولهم ومشاركتهم مـع بعضهم البعض في الملاحظة والاستكثاف وإنجاز المهام.

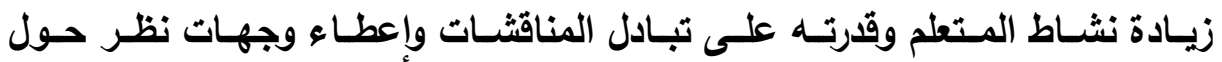
الموضوعات التي يإرسها. تنمية مهارات التفكير الجغرافى للطلاب مثل مهارات (التفسير، والتحليل، والمقارنـة، وحل المشكلات، التفكير الناقد، واتخاذ القرار). • تجعل الطلاب أكثر تفاعلاً وإيجابية في المواقف التعليمية المختلفة. 
• • زيادة التفاعل بين المتطمين والمطعين.

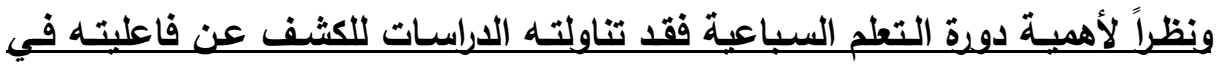

تحقيق نواتج التطم المختلفة، مثل دراسة كل من:

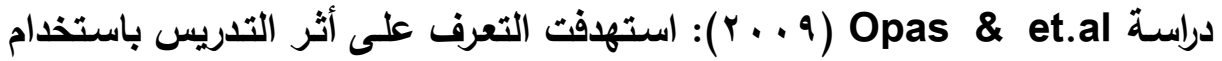

دورة التعلم البنائية Seven E's والذكاءات المتعدة على التحصيل العلمي والتفكير الناقد

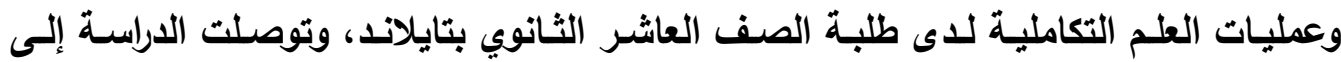
فاعلية دورة التعلم السباعية والذكاءات المتعددة في تنمية التحصيل العلمي، التفكير الناقد، عمليات العلم التكاملية. - مالية

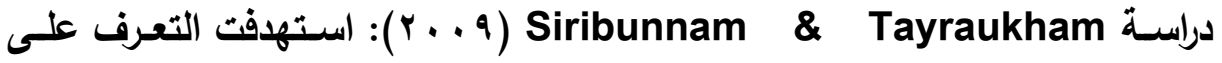
فاعلية استخدام دورة التطم السباعية ونموذج التطلم (K.W.L) في تتمية التفكير التحليلي

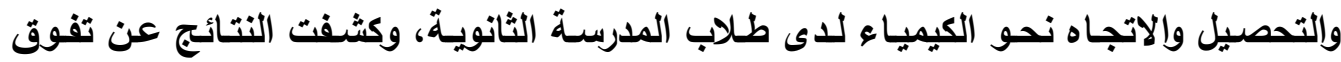
المجموعة التجريبية الأولى التي درست باستخدام دورة التُطم السباعية في كل من التفكير التحليلي والتحصيل والاتجاه نحو الكيمياء. دراسة( Gurbuz \&Mitturgut 2012 ) : استهافت التعرف على أثر استخدام

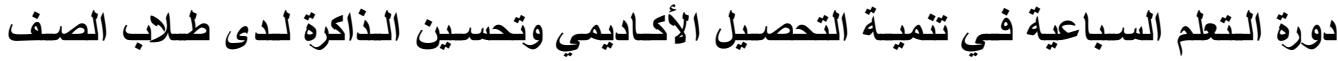

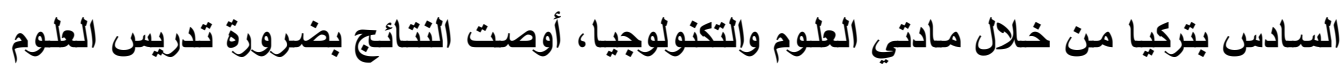
باستخذام دورة التعلم السباعية بشكل أوسع في المراحل الدراسية الأخرى.

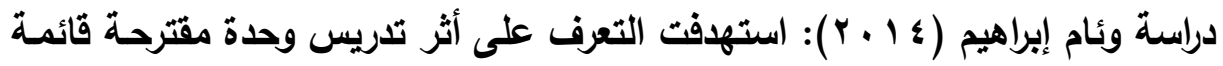

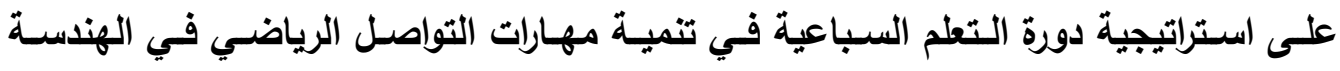

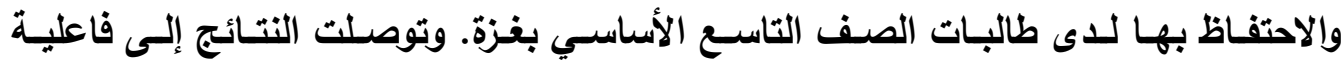
التدريس باستخدام دورة التعلم السباعية في تنمية مهارات التواصل الرياضي والاحتفاظ بها. كما أوصت بضرورة استخدامها في مراحل عمرية ومواد دراسبة مختلفة.

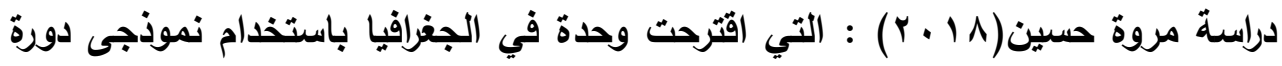

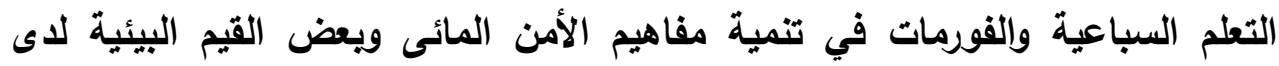
تلاميذ الصف الثانى الاعدادى. 
ويعد توضيح أهمية دورة التعلم السباعية نكون قد انتهينا من عرض المحور الأول ويتم

$$
\text { الانتقال إلى المحور الثانى الأى تثاول محطات التعلم. }
$$

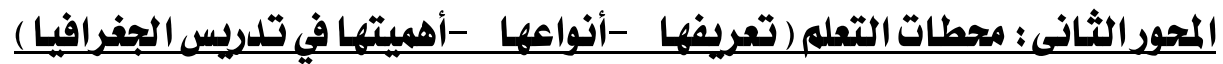

جاء مصطلح محطات التعلم في عديد من الدراسات بمسميات عديدة مثل (المحطات

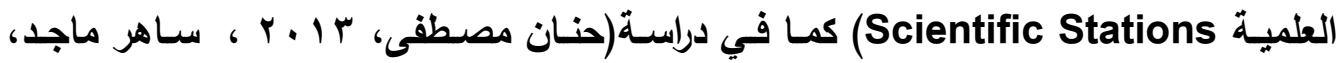

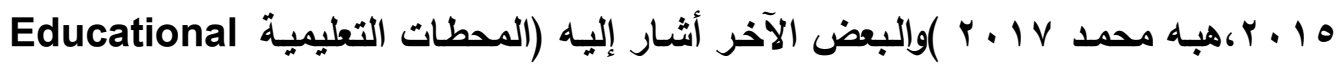

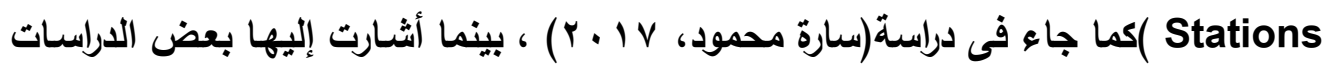

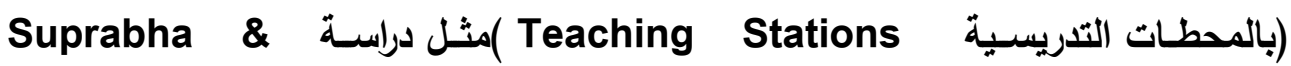
(Subramonian, 2014) Aqel \& ، Dangwal, et.al, 2014) كما جاء في دراسـات (Learning Stations ، Haboush, 2017

تعريف محطات التعلم:

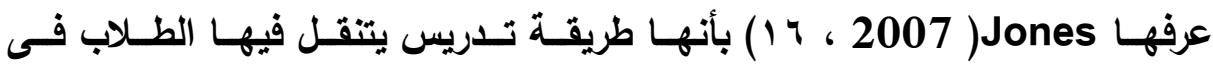
مجموعات صغيرة عبر سلسلة من المحطات مما يتيح للمتعلمين تأديـة كل الأنشطة المختلفة عبر التناوب على المحطات المختلفة، ويمكن للمحطات أن تدعم تدريس المفاهيم المجردة، فضلاً عن المفاهيم التي تحتاج إلى قدر كبير من التكرار، ويمكن للمحطات أن تغطي مفهوم

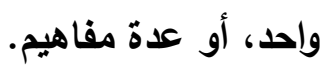
وعرفها ساهر ماجد (10 ب ب) بأنها إحدى استراتيجيات النظرية البنائية والتى تقوم على مجموعة من الأنشطة والتى تتكون من عدة محطات ولكل محطة مهارة أو نشاط يختلف

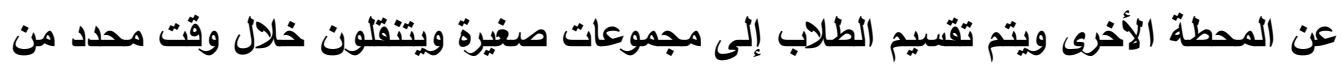
محطة إلى أخرى بالتناوب مما يتيح لكل طالب تأدية جميع النشاطات عبر تجواله بشكل دورى على جميع المحطات.

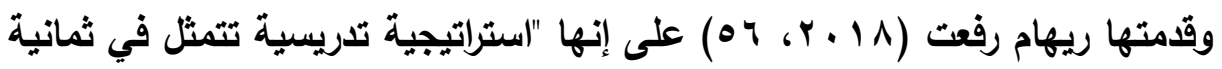
من المحطات تقوم من خلالها طالبات الصف الأول الثانوى بالمرور عليها وممارسة الأنشطة التطليمية الموجودة بكل منها، والتي قد تكون استقصائية، استكثافية، أو بصرية صورية، أو 
إلكترونية ......وغيرها "، مما يتيح لهن العمل في مجموعات صغيرة (ع-7) لتطوير التصورات العقلية للبيئة.

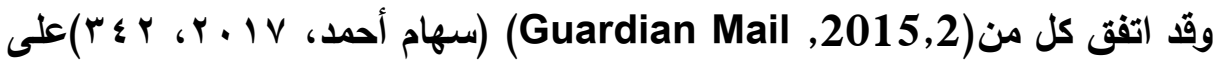

أن محطات التطلم هي مجموعة من الإجراءات التدريسية التي تقوم على عدة محطات تعليمية

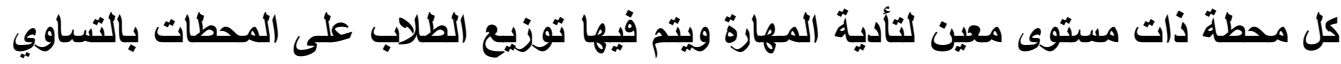
على أن يمر جميع الطلاب بكل المحطات، ويؤدوا المهام حسب ورق العمله العل المتعلق بكل محطة.

وتُعرف استراتيجية المحطات العلمية إجرائياً بأنها: استراتيجية تدريسية تتمثل في مجموعة من المحطات يقوم الطلاب بالمرور عليها وممارسة الأنثطة التعليمية الموجودة بكل

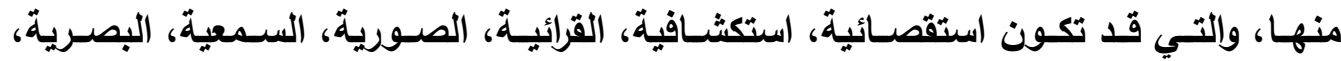
الاككترونية والاستثارية لزيادة نثاط المتعلم وفاعليته في العملية التطليمية.

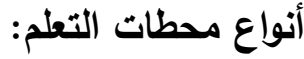
هناك أنواع مختلفة من تطبيقات محطات التعلم، تعتمد في تصميمها على طبيعة كل درس ويمكن الدمج بين هذه الأنواع المختلفة لتصميم نموذج يتلاعم مع طبيعة المتطعين،

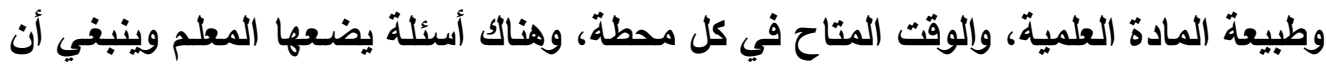
يجيب عنها الطلاب عند تواجدهم في كل محطة من هذه المحطات.

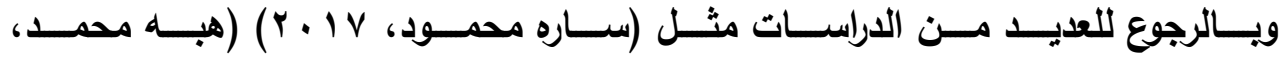

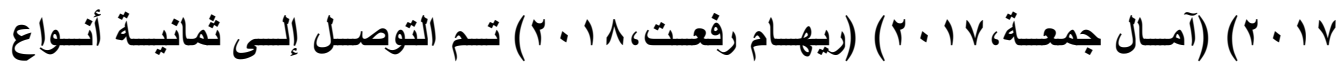

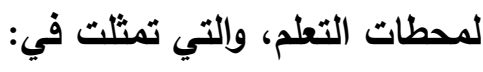
1- المحطة الاستقصائية/الاستكثافية: تهدف هذه المحطة إلى أن يقوم الطلاب بأنفسهر باكتثاف ما هو محدد لهم أو التوصل إلى نتيجة معينة والإجابة عن الأسئلة المصاحبة. وتهتم بالأنثطة العملية التى تتطلب إجراء تجرية معينة ولا يستغرق تتفيذها وقتاً طويلاً. r- المحطة القرائية: وفى هذه المحطة يوضع فيها مادة علمية قرائية كمقال من صحيفة، أو أو

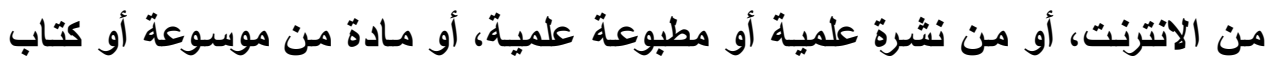

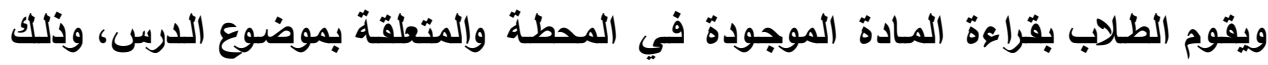

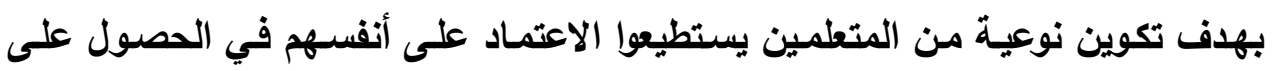


المعلومات ولديهم القدرة على استخراج المعرفة من مصادرها الأصلية، ويمتلكون مهارات الاستقلالية في التعليم بدون الحاجة إلى وسيط كالمعلم أو الكتاب المدرسي، ممـا يزيل من دافعيتهم للتعلم ومن ثم الإجابة على عدد من الأسئلة المصاحبة. r- المحطة الصُورية: تتميز هذه المحطات بوجود عدد من الصور أو الرسومات، يتصفحها الطلاب ويجيبون على الأسئلة المتعلقة بها، وقد يكون مصدر الصور موسوعة علمية، أو ملصقاً جاهزاً، أو قصص علمية مصورة، فتسـاعد الطلاب تقريب المفاهيم العلمية والخبرات المحسوسة إلى أذهانهم. ع - المحطة السمعية/ بصرية: في هذه المحطة يمكن وضع جهاز تسجيل أو فيديو لمشـاهدة

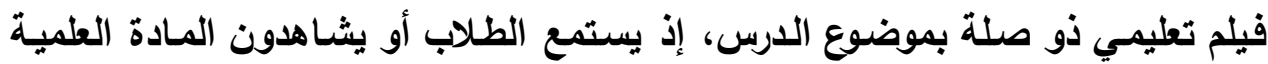

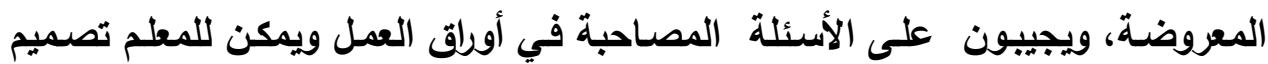
المادة العلمية بمساعدة بعض الطلاب. ه- المحطة الاككترونية: وفى هذه المحطة يوضع جهاز حاسوب ويقوم الطلاب بمشاهدة عرض تقديمي P.P ، أو أفلام تعليمية مرتبطة بموضوع الدرس، أو يقومون بالبحث في في هي الانترنت، ثم الإجابة على الأسئلة المصاحبة لهذه المادة العلمية. צ- المحطة الاستشـارية: تُعدّ هذه المحطة مخصصة للخبراء، فيقف المعلم خلف هذه المحطة، أو استقام زائر كخبير متخصص مهندس أو طبيب له علاقة بموضوع الدرس، وعند وصول الطلاب لهذه المحطة يمكنهم أن يسألوا أيـة أسئلة يقترحونها وتتعلق بموضوع الدرس، في صورة مناقشة فيمكن عندئذ توسيع مداركهم حول الجوانب المختلفة للمادة العلمية، التي لم يستطيعوا فهمها. - Vحطة متحف الثمع: وفى هذه المحطة يطلب المعلم من أحد الطلاب سواء داخل الفصل أو خارجه، تقصص شخصية علمية، مثل أحد العلماء ويرتدى ملابس العصر الذي يعيش مل مله فيه العالم إذا كان من علماء العرب والمسلمين، ومن الأفضل أن تكون أمامـه نماذج من كتبه، أو الأجهزة التي قام باختراعها، أو صور تحكى أهم انجازات هذا العالم، ويتحدث عن مادة علمية مرتبطة بموضوع الارس نفسه. 1- محطـة الــ (نعـم) والـــ (لا ): تعتبـر هـــه المحطـة مـن المحطــات الممتعـة والمثيـرة

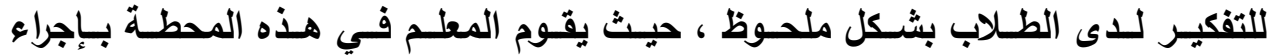




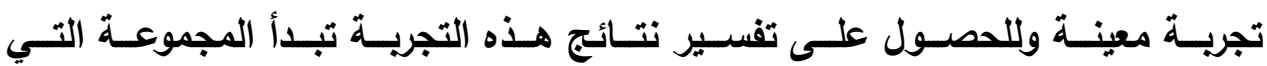
تصل لهذه المحطة بصياغة أسئلة يكون الإجابة عنها بـ (نعم أو لا). أهيبة مجطات التعلم في تلدريس الجغرافيا:

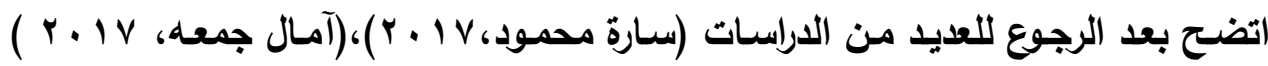

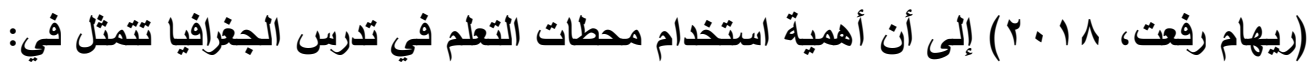

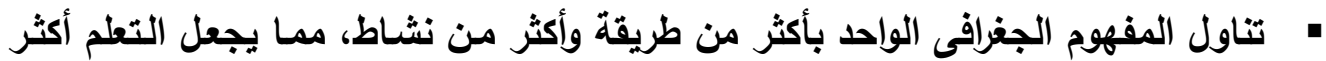
متعة، وأكثر فهمًا، وترابطًا بأذهان الطلاب. • استخذام المصادر العلمية الأصيلة كالموسوعات، والكتب، والأطالس والخرائط، وغيرها على طاولة المحطة القرائية. همارسة الطلاب لأنواع الاكتثاف ينمى لليهم الثقة بالنفس والقدرة على الحصول على المعلومات، واكتثافها بأنفسهم. تنوع الخبرات التعليمية التي يكتسبها الطلاب لتحقيق أهداف الدرس وتلبية أنماط التعلم

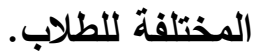
• التظلب على قلـة الموارد ونقص الأدوات والإمكانات المتاحة لممارسة الأنثطة التعليمية

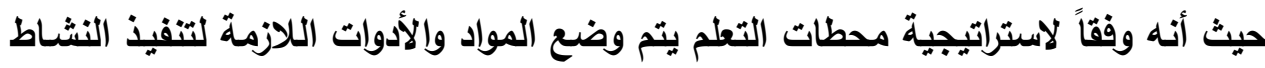

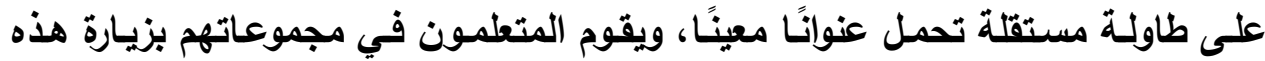
المحطة ويالتالى ليس من الضرورى توفير مواد وأدوات لكل أفراد المجموعات. • إضفاء جو من المتعة نتيجة الحركة والانتقال في الفصل، بعد تقسيم الطلاب في الفصل إلى مجموعات، وتصميم المحطات العلمية وتوزيعها على طاولات في الفصل.

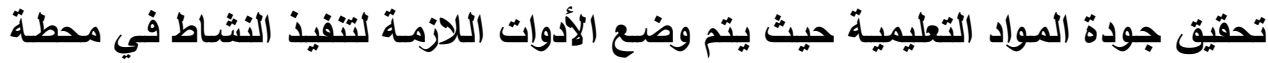
واحدة يمر عليها كل الطلاب في كل المجموعات. تنمية دافعية الطلاب للتعلم من خلال ممارسة العديد من أنواع الأنثطة التعليمية.

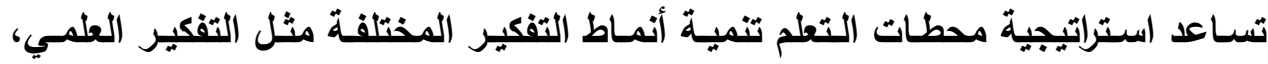

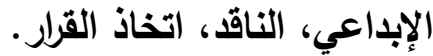
" تنمية العديد من المهارات الاجتماعية، مثل التعاون، ومشاركة الآخرين، وتقبل الرأي، والرأي الآخر، وغيرها، نتيجة انخراط الطلاب فى مجموعات تعاونية. 
ونظراً لأهمية محطات التعلم فقد بحثت العديد من الدراسـات عن فاعليتها وتأثيرها على الطلاب مثل دراسـة Bulunuz ,N. \& Olga,J) 2010 استهدفت الدراسة التعرف على فاعلية استخدام استراتيجية المحطات العلمية في إكسـاب معلمى العلوم للمرحلة الابتدائية بعض المفـاهيم العلمية المرتبطة بـالأرض والفضـاء ومدى انعكاس هذا الفهم على إكساب هذه المفاهيم لطلابهم. دراسـة Ocak, (2010) استهدفت التعرف على فاعلية استخدام محطات التعلم فى مي التحصيل الأكاديمي ومستوى الاحتفاظ بالمادة فى العلوم والتكنولوجيا للى تلاميذ الصف الخامس الابتدائي بإحدى المدارس التركية.

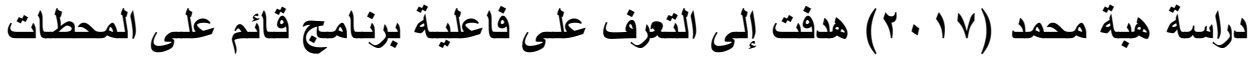
العلمية في تنمية التحصيل ومهارات القرن الحادي والعشرين لاى تلاميذ المرحلة

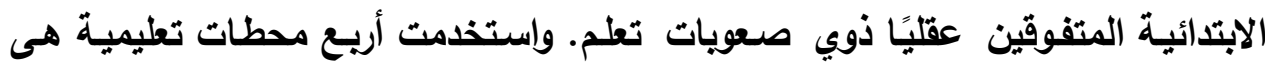
(الاستقصائية/ القرائية / الاكترونية / نعم ولا) وأثارت النتائج إلى فاعلية برنامج قائم على المحطات العلمية في تنمية التحصيل ومهارات القرن الحادي والعشرين لاى تلاميذ المرحلة الابتدائية المتفوقين عقليًا ذوي صعويات تعلم.

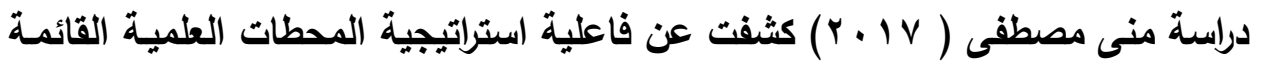
على التعلم التعاوني في تنمية التحصيل العلمي والأداء التتريسي للى طلاب كلية التربية، وقد أشارت النتائج إلى فاعلية استراتيجية المحطات العلمية القائمة على التعلم لمئي التعاوني في تنمية التحصيل العلمي والأداء التدريسي لاى الطلاب.

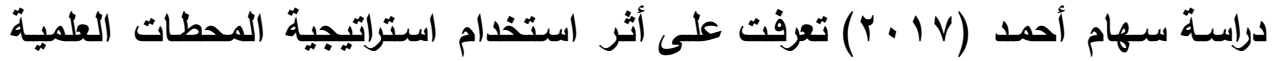
(القرائية / الصورية / الاستكشافية / الاستشـارية / الاكترونيـة) فى تنمية مهارات التفكير الناقد ويعض عادات العقل فى مـادة الاقتصاد المنزلى للى تلاميذ الصف الأول الإعدادى. دراسـة Aqel \& Haboush(2017 استهدفت التعرف على أثر استراتيجية محطات التعلم في تنمية مفاهيم التكنولوجيا للى طلاب الصف السـادس، وأظهرت النتائج أثر استخدام استراتيجية محطات التعلم في تنميـة مفـاهيم التكنولوجيا لـى طلاب الصف 


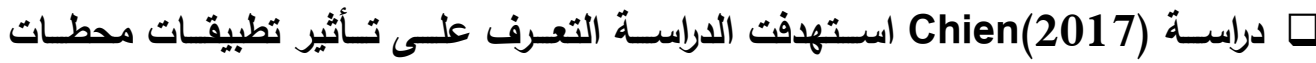

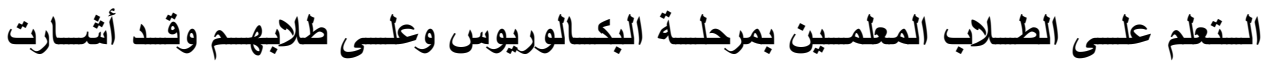

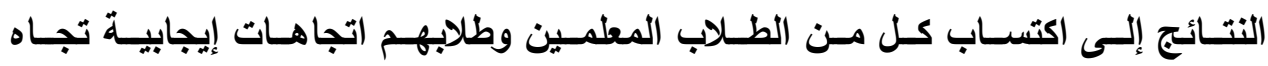

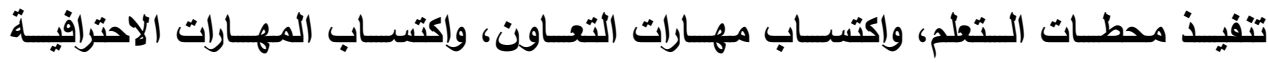

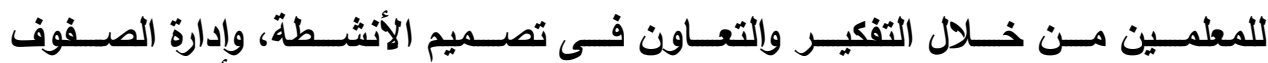
وتنمية المهارات الشخصية مع الطلاب.

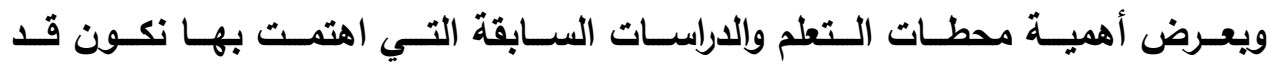

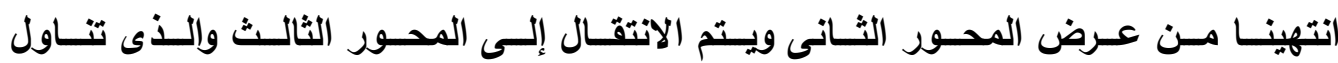

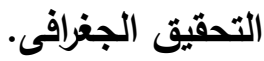

\section{المحور الثالث: التحقيق الجفرافي (تعريفه - مهاراته - أهميته )}

أولاً : تعريف التحقيق الجفرافى:

اختلفت الأدبيات العربية والأجنبية في تحديد مصطلح التحقيق الجغرافى، فالبعض يعتبره استقصـاء جغرافى Geographical Inquiry والبعض الأخر يطلق عليـة تحقيق جغرافى وفئو، والبعض الأخر يعتبره بحث جغرافى، إلا أن هذا البحث يعتبر البحث والاستقصاء من مراحل التحقيق الجغرافى. ولهذا فقد تعددت تعريفات

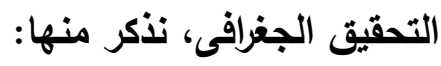

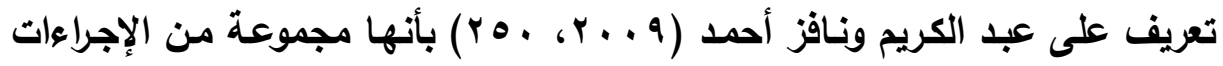
التي يتم فيها وضع المتعلم في موقف تعليمى يثيره ويثككه في ظاهرة من الظواهر الجغرافيـة،

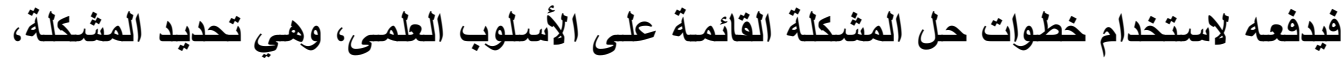
وضع حل تجريبى للمشكلة، وفحص الحل التجريبى، والوصول إلى القرار، وتطبيق القرار. كما عرفه)(Aditomo \& et al, 2011, 3 -2) بأنه مجموعة من الممارسات التعليمية المتمركزة حول المتعلم وتتضمن التحقيق والبحث، ومن ثم يحدث التعلم نتيجة لمعالجة المطلومات من قبل المتعلمين والتوصل إلى إجابات لأسئلة محددة، ويتم عرض هذن فئه النتائج من خلال تحديد وتنظيم وتحليل وتفسير البيانات. 


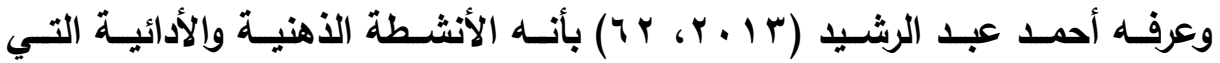

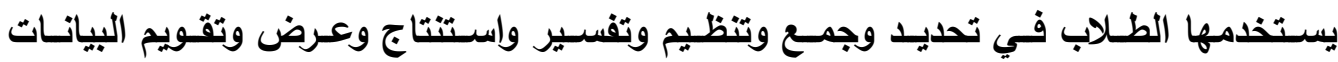
والمعلومات الجغرافية، وتقاس من خلال اختبار مهارات الاستقصاء الجغرافى.

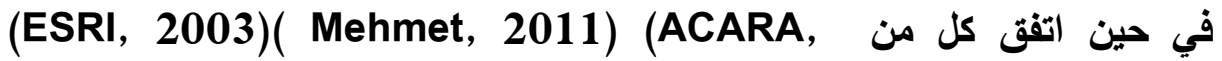
(2013على أنه نمط من أنماط التفكير يُطلق علية التفكير الجغرافي ، ويتضمن ست مهارات وهي : وضع السؤال الجغرافي، تخطيط التحقيق الجغرافي ، جمع وتقييم وإدارة المعلومات الإحساس بالمعلومات ، التواصل ، التفكير في التحقيق الجغرافي ، ويُستخدم فيه ثلاثة أنواع متكاملة من التصورات الجغرافية ، هي : التصور القائم علي المكان ، والتصور المكاني ، والتصور البيئي ويتم ممارسة التحقيق الجغرافي في العمل الميداني الذي يُعد عنصرًا أساسيًا من عناصر التعليم الجغرافي.

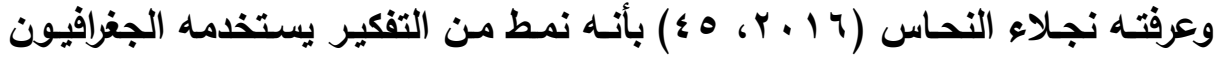
للتعلم حول الجغرافيا، وتعيق فههم لها، ويبدأ بتحديد أهداف التحقيق الجغرافى، وأسئلته/ فرضياته، واختيار تقتياته/ طرقه، وأسـاليب عرض البيانات وتحليلها، وصولاًا إلى تقييم نتائج

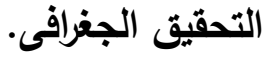

ممـا سبق يتضـح أن التحقيق الجغرافى هو مجموعة من العمليات العقلية والأدائية التي يقوم بها الطلاب متبعين مجموعة من الخطوات المحدة تبأ بتحديد الهدف من التحقيق مئ من الجغرافى ووضع أسئلته، وجمع وتسجيل وتقييم المعلومـات، وتمثيلها وتفسيرها، والإجابة عن أسئلة التحقيق الجغرافى، والتفكير في النتائج التي توصل إليها التحقيق، وذلك بهدف وصول الطلاب للمعرفة الجغرافية الجديدة بأنفسهم وربطها بخبراتهم السابقة.

Geographical Investigation / Inquiry Skills مهارات التحقيق الجغرافى عرضت عديد من الدراسات والأدبيات مهارات التحقيق الجغرافى، منها:

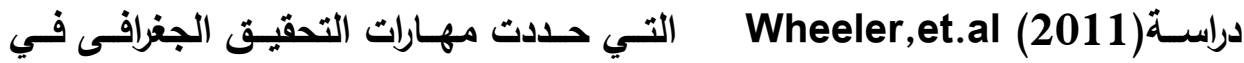
مهارة(الملاحظـة، جــع المعلومـات، حـل المشـكلات، التوصـل للنتــائج ومناقثـتها، التأمـل، 
كما أشارت دراسة(McCright, (2012) إلى أن مهارات التحقيق الجغرافى تتمثل في: الملاحظة: جمع المعلومات حول ظاهرة أو موضوع ما. التصنيف: تصنيف المعلومات إلى مجموعات معينة بينها علاقات متشابهة. القياس: التقرير عن ماهية الأشياء قياساً على شيء معلوم. التبؤ :القدرة على تنبؤ حدوث ظواهر مشابهه مستقبلا. الوصف :وصف الظاهرة أو موضوعات التعلم وصفا يميزها عن غيرها. الاستتتاج: حيث يخلص المتعلم إلى تعميم يجمل فيه جميع العمليات العقلية السابقة. في حين أشار Collins, et.al(2016 أن التحقيق الجغرافي يتضمن ما يلي: • طرح سؤال جغرافي. • جمع الأدلة ذات الصلة (الكمية /أو النوعية) للإجابة على السؤال الجغرافى. • عرض وتحليل الأدلة التي قد تشمل التحليل الإحصائي للبيانات العددية. • استخلاص الاستتاجات: إنشاء الحجة الجغرافية لتفسير الأدلة. • تقييم الأساليب والاستنتاجات.

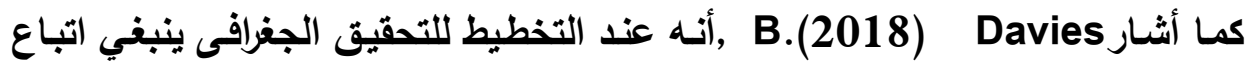

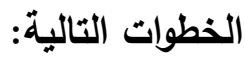
• تحديد الأسئلة التي يمكن الإجابة عليها في وقت محدد والخروج بسؤال بحثي مثل، ما المشكلة التي يمكن حلها وكيف ولماذا وأين ومتى؟ • تحديد الأهداف والغايـات وذلك من خـلال وضـع هدف عام للتحقيق الجغرافى يشـل على الكلمات التالية، تأثير، قياس، تقييم، تحديد. • جــع البيانـات وتحديـ مصـادر الحصـول على المعلومـات (خرائط ورسـوم وانترنـت ومنشورات وكتب). تقييم المخاطر . عرض التحقيق الجغرافى. كما حدت مؤسسة AQA(2018 مهارات التحقيق الجغرافى فى: 


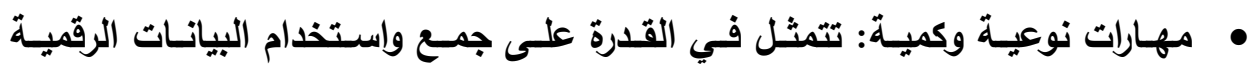

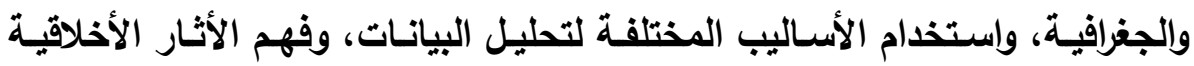

$$
\text { والاجتماعية والسياسية حول البيانات التي تم جمعها. }
$$

• مهارات محددة: وتتمثل في استخدام الخرائط وتوضيح الأمساكن عليها، واستخذام الصور الفوتوغرافية والرسوم البيانية.

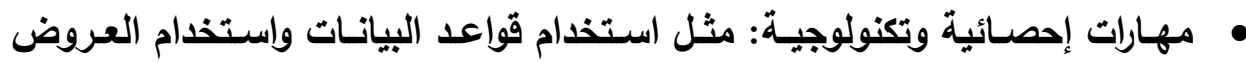
التقديمية. كما أشـارت (ACARA, 2013) الى خمس مهارات خاصـة بالتحقيق الجغرافى يستخدمها الطلاب للحصول على المعرفة الجديدة، ومحاولة فهم وتفسير ما تم ملاحظته، وتنقسم مهارات التحقيق الجغرافى إلى: ا-الملاحظة، وطرح الأسئلة، والتخطيط Observing, Questioning and Planning • يصوغ أسئلة للتحقيق الجغرافى. • يتزم التحقيق الجغرافي طبقا لأهداف محددة بوضوح ومنهجية ملائمة.

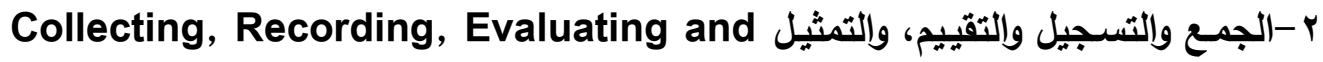
:Representing • جمع المعومـات الجغرافية، ودمج البروتوكولات الأخلاقية من مجموعة من المصادر الأولية والثانوية. ت تسجيل الملاحظات، والمعلومات، وتمثيلها في مجموعة واسعة من العروض الإني

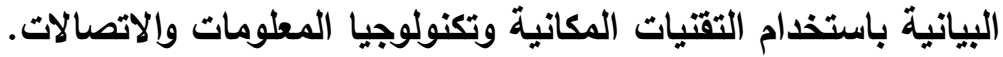
• تقييم موثُوقية وصحة وفائدة المصادر الجغرافية والمعلومات.

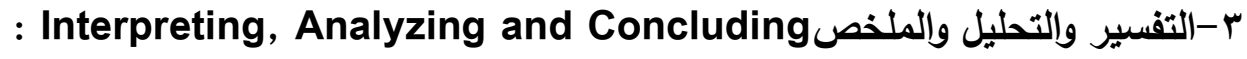
• تليليل المطومـات الجغرفيـة والبيانـات مـن مجموعـة مـن المصـادر الأوليـة والثانويسة ومجموعة متنوعة من وجهات النظر للوصسول إلى استتناجات منطقية وتعميمات.

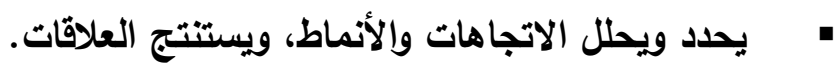


ع -التواصل:Communicating

• توصيل المعلومـات الجغرافيـة، والأفكار والقضـايا والحجـج باستخدام الأثنكال

المناسبة الخطية والثفوية، ورسم الخرائط والرسوم البيانية.

يستخدم لغة الجغرافيا في سياقات مناسبة لإثبات المعرفة الجغرافية والتفاهم.

Reflecting and Responding: التأمل والاستجابة

• يطبق التعميمـات لتقيـيم اسـتجابات بديلـة للقضـايا الجغرافيـة في مجموعـة

$$
\text { متنوعة من المقاييس. }
$$

يقترح العمل الفردي والجمـاعي، مـع الأخذ بعين الاعتبار العوامل البيئية

\section{والاجتماعية والاقتصادية؛ والتتبؤ بنتائج العمل المقترحة.}

مما سبق يتضح أن مهارات التحقيق الجغرافى تسعى لتحديد مشكلة جغرافية تحتاج

لحلول واقعية أو موضوع جغرافي يحتاج لتفسير، ثم تضع الأسئلة وتعققها وتطورها، وتجمع المعلومات وتقيمها وتفسرها وتمثلها في أشكال ورسوم مناسبة، ثم تستخلص النتائج وتحللها. وفى النهاية تأتى مرحلة التفكير في نتائج التحقيق والتأمل فيها، ونقلها باستخدام مجموعة متتوعة من الاستراتيجيات المناسبة.

\section{أهمية تنمية مهارات التحقيق الجفرافى للطالاب :}

باستقراء العديد من الأدبيات والدراسات مثل (Mehmet, (Wheeler, et.al ,2011)

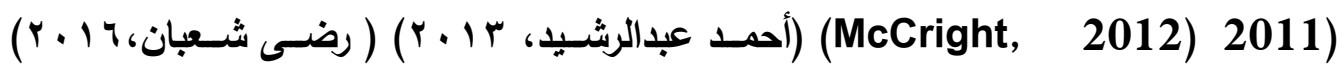
(Collins, et.al,2016)

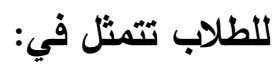

اكتساب مهارة تحديد المشكلة أو القضية الجغرافية تحديداً دقيقاً.

• مساعدة الطلاب في تحقيق الهدف العام من التحقيق الجغرافى. • تنمية قرتهم على طرح الأسئلة المتنوعة والعميقة عند التخطيط للتحقيق.

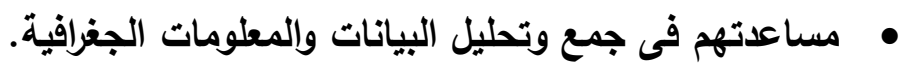
• تقييم موثوقية وصحة المصادر الجغرافية والمعلومات. • تعميق فهم الطلاب وإثارة فضولهم العلمى. 
اختيار ويناء واستخدام التمثيلات العقلية المناسبة لشرح العلاقات والأنماط المكانية والاتجاهات.

تقــيم التفسـيرات والاسـتنتاجات فـي أشـكال مكتويـة، أو شـفوية، ورسـوم بيانيـة وتوضيحية.

إقامة الروابط وإلعلاقات بين المعارف الجديدة والخبرات السابقة. مسـاعدة الطـلاب في معرفتهم بالقضـايا الاقتصـادية والاجتماعيـة والسياسية التـي تشغل وطنهم. تنمية مهارات التعلم الأتي، وزيادة ثقة الطلاب بأنفسهم. تتمية مهارات حل المشكلات والتفكير الناقد لاى الطلاب. بناء مواطن يتمتع؛ بالمسئولية والكفاءة والمشـاركة المدنية على المستوى: المحلي

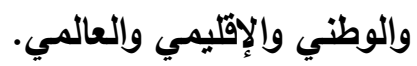
Wheeler, et.al (2011) ونظراً لأهمية مهارات التحقيق الجغرافى فقد أكدت دراسـي على أهميتها في بنـاء ثقة الطلاب وتطوير قدراتهم الثخصية وزيـادة قدرتهم على العمل الجماعى والتأمل، وأوصت الاراسـة بضرورة تنمية هذه المهارات على عدة جلسـات تدريبية لكي يتقتها الطلاب ليكونوا أفراداً أكثر استقلالا وتميزاً في المستقبل. كمـا استخدمتها دراسـة (Lim EN Qi, 2018) في تتميـة التفكير المعرفى لطلاب المرحلـة الثانويـة بسنغافورة، وجـاوت نتائج الدراسـة مؤكدة على إظهار تحسن في مستوى

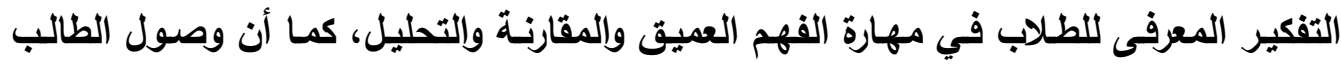

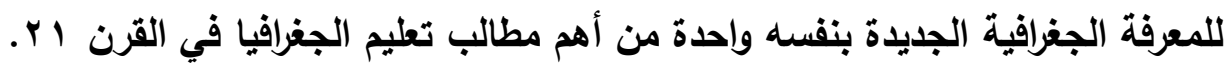
ويعد الكشف عن أهمية تنمية مهارات التحقيق الجغرافى نكون قد انتهينـا من المحور الثالث ويتم الانتقال إلى المحور الرابع والأخير والذى بين التمثيل العقلى للمعلومـات من حيث تعريفه وأهميته. 
المحور الرابح: التمثيل العقلى للمعلومات ( تصريفه -خصائصه - أهميته )

تعريف التمثيل العقلى للمعلومات :

يعـــ التمثيـل العقلـى للمعلومــات ركنـاً أساسـياً لجميــع أنـواع المعرفـة الإنسـانية

لأن المعلومـات التــي تنبـتق عـن الخبـرات الحسـية يـتم ترميزهــا بحيـث تـرتبط بـالخبرات السـابقة التـي تـم تخزينهـا في المــخ، فهـي عمليـة اسـتخلاص للمعلومـات مسن الخبـرات

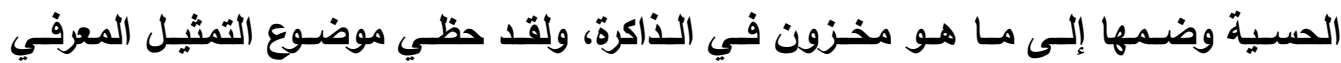

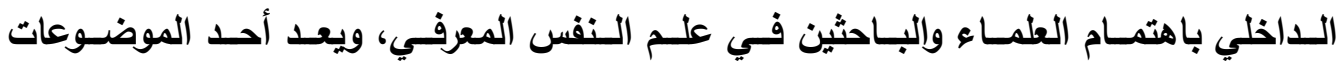

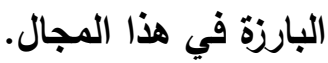

وقد تعددت تعريفات التمثيل العقلى للمعلومات منها :

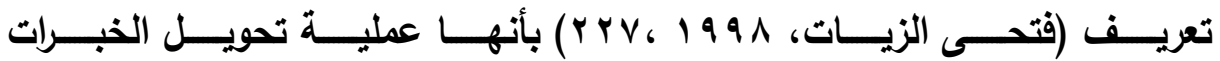

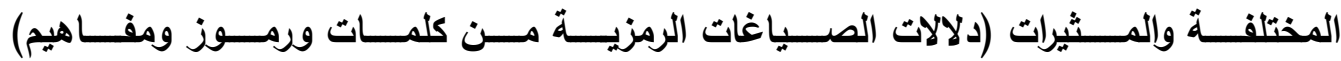

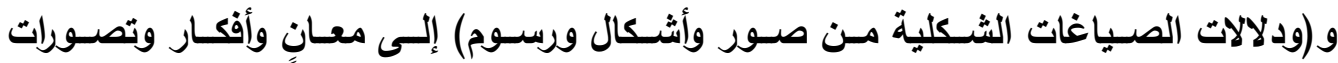

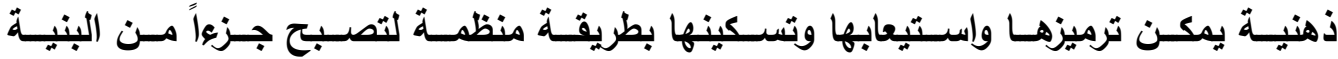

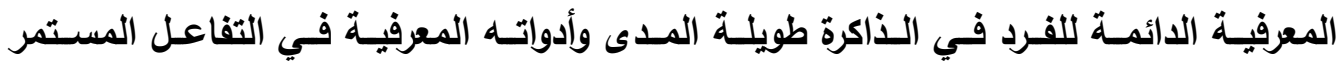

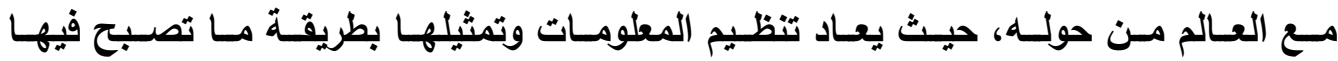
المعلومات جاهزة للاسترجاع وقت الحاجة.

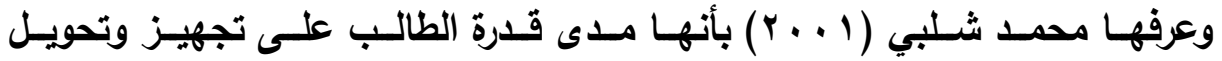
المعرفـة المدخــة مسن صــورتها الخـام التـي تسـتقبل بهـا إلـى عـدـد مـن الاشــتقاقات أو

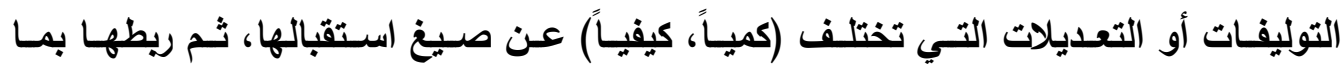
في ذاكرته وتسكينها لتصبح جزعاً من بنائه المعرفي.

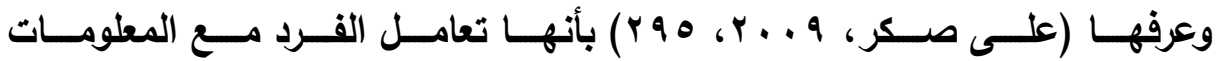

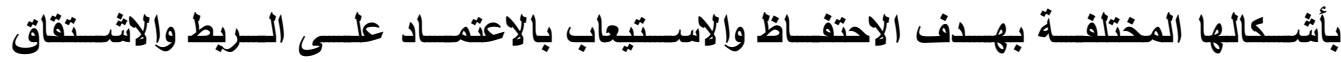

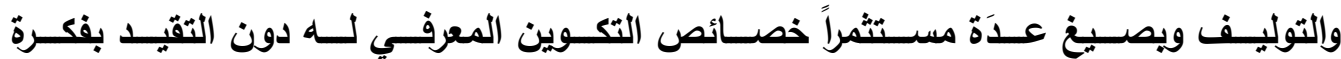
جامدة سعياً إلى تطوير أبنيته المعرفية.

ويعـــ عـرض هـــه التعريفـات يمكـن تعريـف التمثيـل العقلـى للمعلومــات إجرائيـاً بأنهـا: قـدرة الطـلاب على اكتسـاب المعلومــات وتحويلهـا وترميزهـا إلـى صـيغ وتصـورات 
عقليـة مـن خـلال عمليـات الـريط والاشـتقاق والتتوليـف وذلـك لتخزينهـا فـي الــاكرة طويلـة المدى واسترجعها عند الحاجة. خصائص التمثيل العقلى للمعلومات : - خ

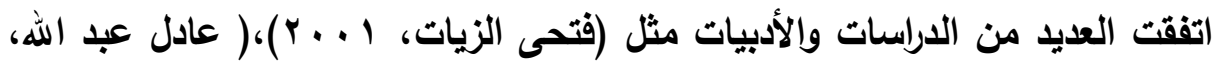

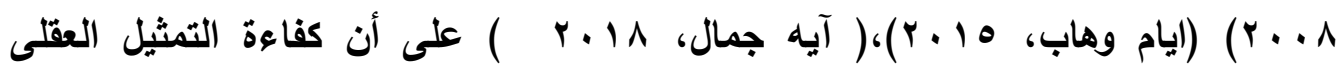
للمعلومات تتوقف على مجموعة من الخصائص وهى كالتالى: 1. خاصية الاحتفاظ: وهى الاحتفاظ القصدى بالمعلومات والمعارف القائمسة على إدراك أهمية هذه المعلومات سواء كانت مستدخلة أو مشتقة للاستخدام أو التوظيف اللاحق.

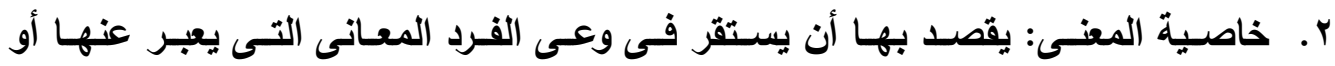
يستهدفها المحتوى المعرفى موضوع المعالجة. r. خاصية الاشتقاق: يقصد بها أن بعكس البناء المعرفى للطالب وصور التعبير عنه صيغا من المعلومات الجديدة تختلف فى الكم وإلكيف عن العناصر الخام المستدخلة فيها. ع. خاصية التوليف: ويقصد بها توظيف واستخدام العناصر بالتعديل أو الحذف لصياغة نواتج معرفية مختلفة لكنها تعكس نفس مذاق تلك العناصر أو الوحدات. ه. خاصية تعدد صيغ التمثيل المعرفى: ويقصد بها تعدد الأوعية أو الأطر والاستراتيجيات التى يقوم عليها التمثيل المعرفى أفقيا أو رأسيا بالتزامن أو بالتعاقب اعتمادا على التنظيم الأتى أو تنظيم العرض.

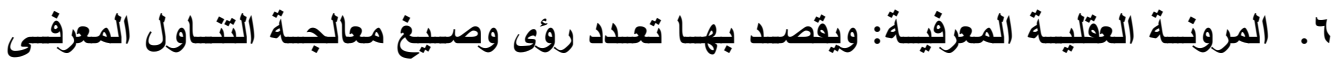
للمدخلات المعرفية المستـخلة أو المشتقة وعدم الاعتمـاد على الصيغ الشكلية للتمثيل المعرفى.

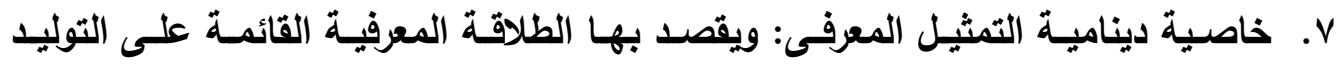
والتوليف والاشتقاق للمعلومات. 
أهمية التمثيل العقلى للمعلومات :

يعدّ التمثيل العقلى وسيلة فعّالة تؤثر في عملية التعلّم والبناء المعرفي لدى الفرد، حيث تصبح لايه قدرات عالية في بناء واشتثقاق المعلومات وإنشاء العلاقات بينها، ويذلك تتكوّن لايه قاعدة معلوماتية يستطيع من خلالها إنشاء مخططات وخرائط تساعده على بلى

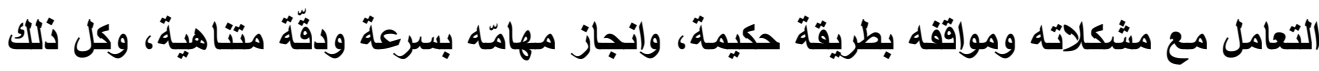

يساهم في تطوير العمليات العقلية لايه من إدراك وفهم وترميز وتفكير وحل مشكلات.

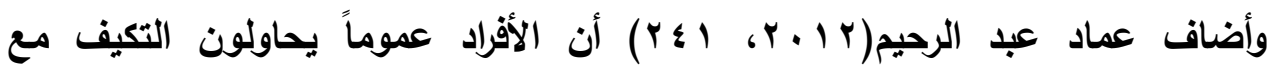
المثيرات البيئية من خلال توظيف ما لايهم من بنى معرفية، وهذا من شأنه أن يسهم في

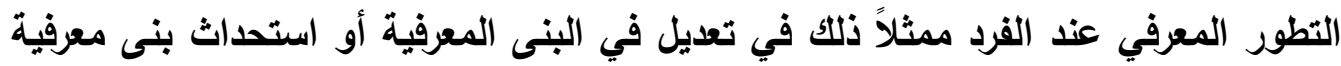
جديدة، مما يتيح للفرد تحقيق التوازن محققاً بذلك كفاعة للتمثيل المعرفي.

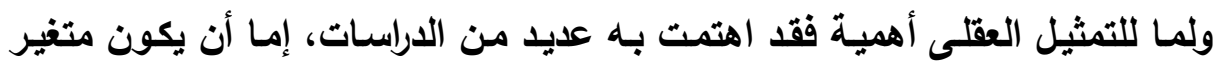
مستقل يتم البحث عن مدى تأثيره في العديد من نواتج التعلم أو أن يتم معرفة مدى تأثير

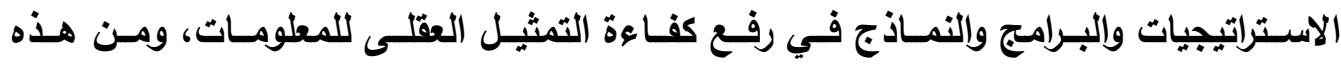
الأراسات:

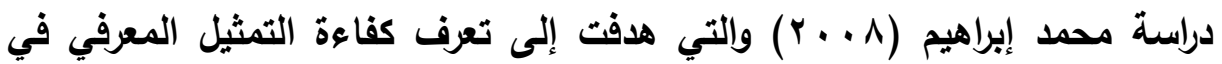
ضوء نموذج بيجز الثثلاثي لاى عينة من الطلبة، وتتاولت الدراسة مدخلين للتعلم هما:

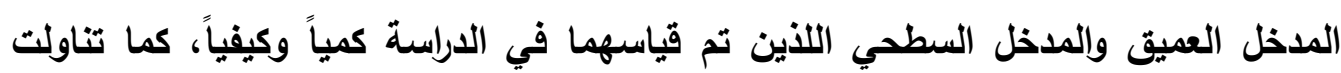
الدراسة كفاعة التمثيل المعرفي للمعلومات في علاقتها بنواتج التعلم (النواتج الكمية والنواتج الكيفية) طبقاً لتقسيم سولسو، وقد أشارت نتائج الدراسة إلى وجود علاقة ارتباطية دالة بين درجات الطلاب في مدخل التعلم العميق ودرجاتهم في كفاءة التمثيل المعرفي للمعلومات.

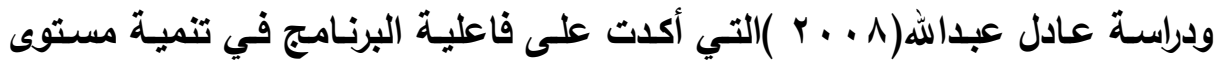
التمثيل العقلى لاى تلاميذ الصف السادس الابتدائي ذوي صعويات التعلم كما تحسن مستوى تجهيز التلاميذ للمعلومـات ومعالجتهم لها، وتحسين مستوى الفهم القرائح، وتنمية مهارات حل المشكلات. 
وهدفت دراسـة عبد العزيز حيدر(7 1 ـ ب) إلى التعرف على كفاءة التمثيل المعرفي

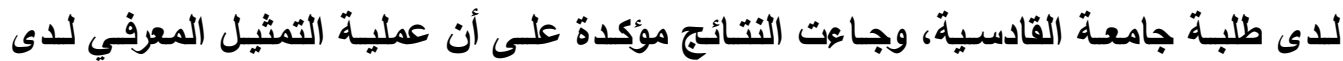
الطلبة تتم بطريقة ذات كفاعة عالية فهم يتمكنون من استاخال المعلومـة واستيعابها ومن ثم ترميزها وإحلالها في بنيتهم المعرفية على نحو فعال بما يلائم قدراتهم، وأوصت بضرورة الأخذ بالحسبان من القائمين على العملية التعليمية مراعاة الفروق الفرديـة بين الطلبة في كفاءة التمثيل المعرفي عند قيامهم بتدريس المادة العلمية، وإثراء المنـاهج التعليمية بالمحتوى الذي هري يعتمد على مهارات التفكير المختلفة التي تعمل على زيادة التمثيل المعرفي. دراسة سالم الغرايبة ومنى السديرى(1 I • Y) التي هدفت التعرف على كفاءة كل من التمثيل العقلى للمعلومـات ومهارة حل المشكلات والعلاقة بينهم للى طالبات جامعة القصيم بالمملكة العربية السعودية، وجاءت النتائج مؤكدة على أن هناك علاقة بين التمثيل العقلى

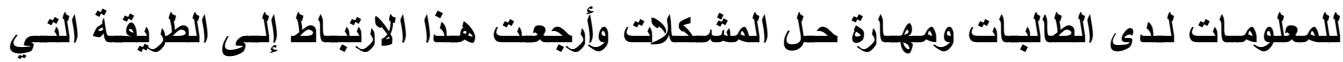
تستخدمها الطالبات في التمثيل العقلى عن طريق ربط العناصر والمفاهيم والحقائق معاً ممـا جعلها تؤثر في اختيار الاستراتيجيات المناسبة لحل المشكلات. كمـا أن هنـاك دراسـات بحثت عن العلاقة بين التمثيل العقلى للمعلومـات ومتغيرات

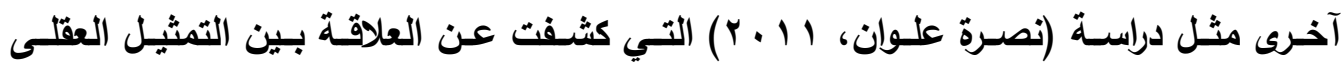

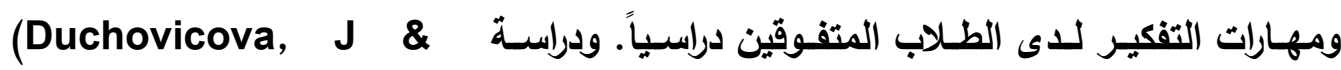
Kozarova,N.2017) الحركي، اللمسي ) والتمثيل العقلى لاى طلبة المرحلة الثانوية. ويالوصـول إلـى أهميـة التمثيـل العقلى للمعلومـات ومـدى الاهتمـام بـه مـن الدراسـات والادبيات نكون قد انتهينا من الجزء الأول من البحث وهو الإطار النظرى، وسنتتقل إلى جزء

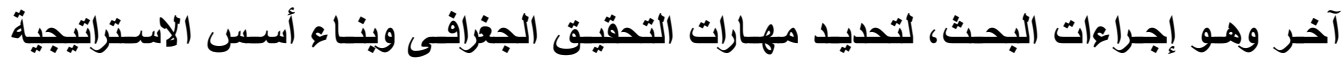
المقترحة وقياس أثرها، والخروج بالنتائج والتوصيات والمقترحات. 


\title{
احراوات البحث
}

أولاً : بناء قائمة بمهارات التحقيق الجفرافى الواجب تنميتهـا لطلاب الصف الأول الثـانوى

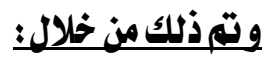

ا. تم التوصل إلى قائمسة مبائية بـالتحقيق الجغرافى من خلال مراجعة الأدبيات والدراسـات

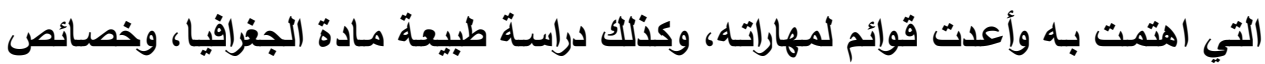
طلاب المرحلة الثانوية.

r. قد حددت القائمسة المبئيسة في (•) مهارات رئيسية وهـى (تحديد الهـف من التحقيق الجغرافى ووضـع أسئلته، جمع وتسجيل وتقييم المعلومـات، تمثيل المعلومـات الجغرافية وتفسيرها، الإجابـة عن أسئلة التحقيق الجغرافى، الانعكاس والاستجابة)، وتفرع منها

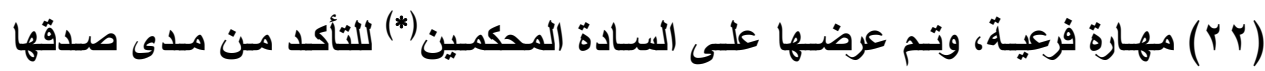
وأهميتها ومناسبتها لطلاب الصف الأول الثانوى. r. تم تعديل القائمسة بنـاء على رأى المحكمين، وذلك بحذف مهارتين فرعيتين وهما (مهارة

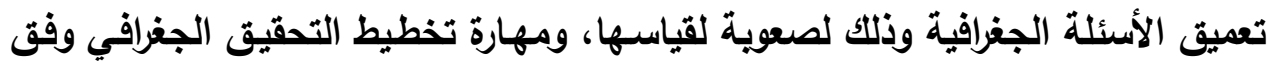
أهداف محددة) لتصبح القائمـة في صورتها النهائية(*) مكونـة من (•) مهارات رئيسية

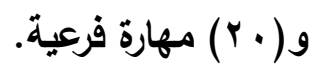

ثانياً : تحليل أسس الاستراتيجية المقترحة القائمة على الدمجج بـين دورة التعلم السبياعبة ومحطات

التعلم: و تم ذلك من خلال :

1. مراجعة الأدبيات والدراسات التي اهتمت بدورة التعلم السباعية ومحطات التعلم من حيث تعريفهم وأهميتهم في تدريس الجغرافيا، والأسس التي قاموا عليها، ومراحلهم التدريسية، وكذلك مراجعة أهداف تنمية مهارات التحقيق الجغرافى. r. تحديد الهرف من الاستراتيجة المقترحة.

\author{
( ) ملحق رقم ( ) مائمة السادة المحكمين. \\ ( * ) ملحق رقم (ץ) قائمة مهار ات التحقيق الجغر افى في صورتها النهائية.
}


تهدف الاستراتيجية المقترحسة القائمسة على اللدمج بين دورة التعلم السباعية

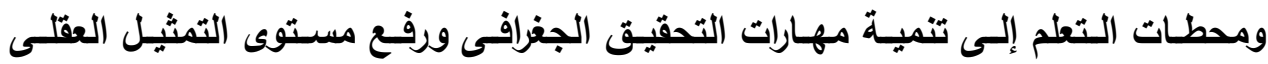
للمعلومات لطلاب الصف الأول الثانوى. r. تحديد الفلسفة القائمة عليها الاستراتيجة المقترحة.

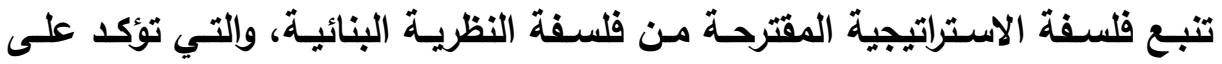
كيفية اكتساب عقل الطالب المعلومـة الجديدة وريطها ميع خبراته السـابقة، وكيفية معالجته للمعلومات وصولاً للتعلم ذي معنى. كما تتبع فلسفة الاستراتيجية المقترحة من التخطيط التوليفى، وهو ما أكده الكثيرين بأنه إذا كان هناك العليد من الاستراتيجيات لها مميزاتها التي تظهر عند إجرائها بثكل فردي، ولكن تجتمع هذه المميزات مع بعضها عند نسج استراتيجيتين أو أكثر، ومن ثم يكون التأثير كبير، ولهذا تم دمج دورة التعلم السباعية ومحطات التعلم للخروج باستراتيجية مقترحة. ع. تحديد مبادئ الاستراتيجية المقترحة.

$$
\text { تحددت مبادئ الاستراتيجية المقترحة في: }
$$

• • التأكيد على أن نثاط المتعلم وإيجابيته شرط التعلم.

• تنويع طرق وأساليب التدريس لتشمل عمليات قرائية وسمعية ويصرية وإلكترونية. • تفاعل الطلاب مع بعضهم البعض وتواصلهم الاجتماعي يحسن عملية التعلم. تزويد الطلاب بمهارات الاستقصاء والاكتثاف والتحقيق. زيادة قدرة الطلاب على التمثيل العقلى للمعلومـات التي يكتسبوها لتخزينها بثكل التهل

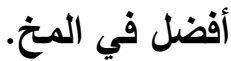

زيادة قدرة الطلاب على اكتساب المطلومـات بأنفسهم عبر مصادر التعلم المختلفة (ئلة فئل كتب ومجلات ومواقع وأطالس وخرائط). • تنمية مهارات التعاون، ومشاركة الآخرين، وتقبل الرأي، والرأي الآخر. تنمية مهارات حل المشكلات وإدراك العلاقات. تحقيق متعة التعلم داخل الفصل وخارجة. تنويع استخدام التمثيلات المعرفية مثل(رسوم بيانيـة وخرائط- - رسوم توضيحيةخرئط معرفية)لعرض المحتوى العلىى للطلاب. 
• تــوع الخبرات التعليميـة بمـا يسـاهم فى تحقيتق أهداف الـدرس وتلبيـة أنمـاط التعلم المختلفة للطلاب. تنمية مستوى الثقة بالنفس لاى الطلاب. تقويم الطلاب ما توصلوا اليه من معلومات. ه. تحديد مراحل الاستراتيجة المقترحة.

تـم تعديـ مراحل الاسـتراتيجية المقترحسة بعد دمـج دورة التعلم السباعية ومحطـات التعلم، بحيث تساعد على تنمية مهارات التحقيق الجغرافى ومستوى التمثيل العقلى للمعلومـات لاى الطلاب. وتمثلت هذه المراحل في: 口ـ مرحلة الإثارة ووضع الأسئلة:

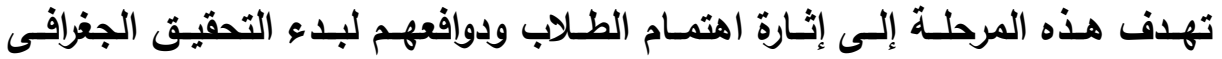
لموضوع أو مشكلة أو قضية جغرافية، وذلك من خـلال وضـع هدف عام للتحقيق، وتخطيط

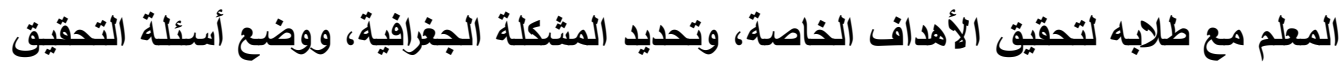
الجغرافى.

\section{口 مرحلة المشاهدة والجمع:}

وفى هذه المرحلة يقوم الطلاب بتصفح مـا يعرضسه المعلم عليهم من صور ورسوم وأثـكال توضسيحية عـن الموضـوع الـذى يـتم دراسـته، وكــلك مشـاهدة الفيـيوهات، وقـراءة المقـالات والخــرائط، وكتابـة الملاحظـات واســتنتاج معلومــات وييانـات جغرافيـة أكثـر دقـة وموضوعية عن موضوع الدراسة.

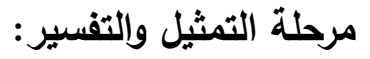
وتهاف هذه المرحلة إلى زيادة قدرة الطلاب على تمثيل المعلومات التي تم مشـاهدتها وجمعها في أشكال وخرائط معرفية وجداول ورموز، وكذلك كثف الطلاب عن العلاقات بين

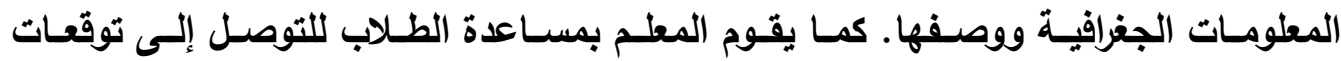




$$
\text { مرحلة الإجابة والتحقق: }
$$

وتهدف هذه المرحلة إلى الإجابة عن أسئلة التحقيق الجغرافى، ويوجهـ المعلم طلابهـ

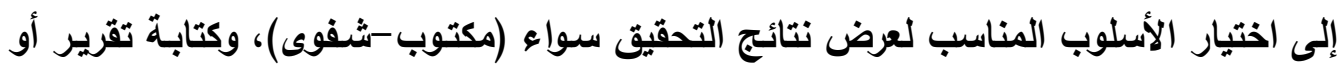
مقالة عن القضية أو المشكلة الجغرافية التي تناولها التحقيق. مرحلة التقويم والتأمل:

وفى هذه المرحلة يقوم الطلاب بمناقشـة جماعية للنتائج التي توصل إليها التحقيق، وتقييم نتائج التحقيق لتحديد ما تم تعلمه. צ. دور المعلم في تثفيذ الاستراتيجية المقترحة:

تقسيم الطلاب إلى مجموعات بحيث لا تقل عن ه طلاب في المجموعة، وتحديد دور كل طالب في المجموعة.

إثـارة التشـويق وجذب الاتتبـاه للتعلم، وذلكك مـن خـلال التخطيط لأنشطة مرحلـة الإثارة بحيث تتضمن مجموعة من الأساليب التعليمية اللازمة للكشف عن الخبرات السابقة لاى الطلاب، وإثارة فضولهم نحو التعلم الجديد. اعداد أوراق العمل الخاصة بكل نشاط. مسـاعدة الطـلاب في تحديد المشـكلة أو الموضـوع أو القضسية الجغرافيـة تحديـاً دقيقاً. مساعدتهم في وضع هدف عام للتحقيق الجغرافى. عرض صور وأثكال وخرائط حول القضية أو المشكلة الجغرافية. مساعدتهم في وضع أسئلة عن التحقيق الجغرافى أكثر تنوعاً وعمقاً. تثجيعهم على البحث والاستقصاء والمشاهدة وتسجيل ما يجمعونه من معلومات.

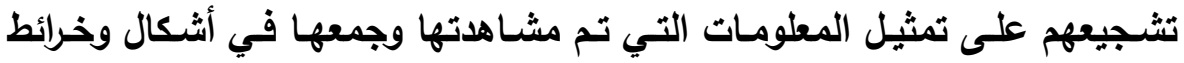

$$
\text { معرفية وجداول. }
$$

مساعدتهم في اختيار الاسلوب المناسب لعرض نتائج التحقيق. إعطاء فرص للطلاب للمناقثة وإبداء الرأي، وتثجيعهم على العمل معاً. الاستماع للمتعلمين والتحقق من مشاركتهم في إجراءات عمل التحقيق الجغرافى. الانتقال من مرحلة إلى أخرى بعد التأكد من إتمام الطلاب المهام المكلفين بها. 
• تقديم التخذيـة الراجعة للطلاب بعد الانتهاء من المراحل الخمسـة، وتقويم النتائج

$$
\begin{aligned}
& \text { التي توصل إليها الطلاب وتحديد ما تم تعلمه. } \\
& \text { V. دور المتعلم في تنفيذ الاستراتيجية المقترحة: }
\end{aligned}
$$

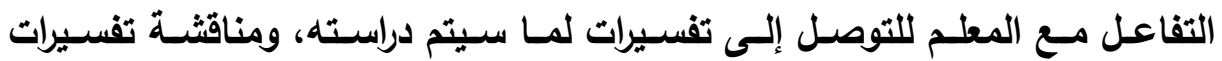

الآخرين، والاستماع لبعضهم البعض، والتعاون فيما بينهم شرط تحقيق التعلم.

• تحديد هدف التحقيق، ووضع أسئلة متثوعة لتشمل كل جواتب التحقيق.

القيام بعمل الأنثطة الفردية والجماعية أثناء إجراء التحقيق الجغرافى.

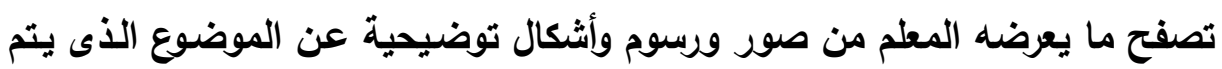

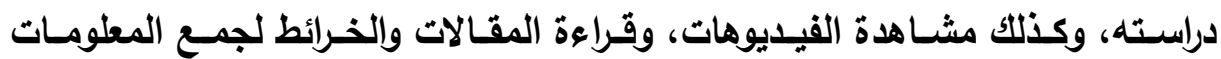
الكلازمة للتحقيق.

تسجيل الملاحظات والمعلومـات التي يتم التوصل إليها من مصادر التعلم المختلفة، وتقييم مدى ملاعمتها ومناسبتها للتحقيق. • تمثيل المعلومـات التـي تـم مشــاهدتها وجمعهـا في أشـكال وخـرائط معرفيـة وجـاول ورسوم توضيحية.

البحث عن العلاقات والروابط بين المعلومات الجديدة والمعلومات السابق تعلمها. الوصول إلى توقعات واحتمالات جديدة من المعلومات المعروضة. الانتقال والتجول داخل الفصل أثناء عمل المجموعات للاستفسار. • البحث عن إجابات لأسئلة التحقيق الجغرافى. تفسير الإجابات والحلول التي تم التوصل إليها.

ثالثاً : إعادة صياغة وحلدة ( الأنشطة الاقتصادية في مصر ) في ضوي الاستراتيجية المقتر حة التي تي التوصل إلبهـا، و تم ذلك من خلال: 1. تحديد الأهداف العامـة والإجرائية للوحدة: تم صياغة الأهداف العامـة والإجرائية للوحدة

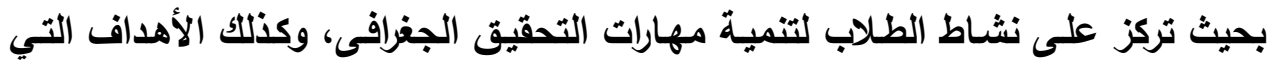
تعمل على رفع كفاءة التمثيل العقلى للمعلومات لدى الطلاب. r. ت تحديد الأنشطة والوسائل التعليمية المناسبة لتدريس الوحدة: تنوعت الأنشطة التعليمة داخل الوحدة وتم دمج أنشطة فردية وأنشطة جماعية لتحقيق أهداف الوحدة، وقد ركزت الوتل 
الأنشـة على عمليـات طرح الأسـئلة، وجمـع المعلومـات ومناقشتـها وتمثيلها وعرض المعلومات والتتبؤ بفرضيات جديدة بناء على خبراتهم السـابقة، وكتابة تحقيقات وتقارير جغرافية منها (سد النهضة-ارتفاع الدولار وتأثثره على الأنثطة الاقتصادية في مصر -

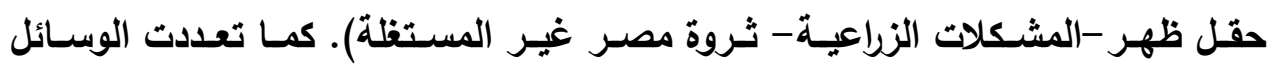
التعليمية فقد اشتملت الوحدة على صور ورسوم بيانية وتوضيحية، وفيديوهات تعليمية

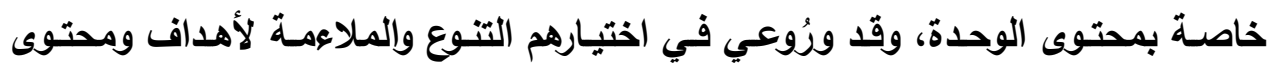

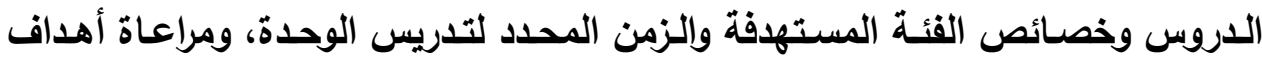
البحث. r. تحديد أسـاليب تقويم الوحدة: فقد تنوعت أسـاليب التقويم بين التقويم القبلى والتكوينى والنهائى. ع. اعداد دليل المعلم لتدريس الوحدة المعاد صياغتها: فقد تم إعداد دليل إرشادى للمعلم لمساعدته في تدريس الوحدة المعاد صياغتها في ضوء الاستراتيجية المقترحة، وتضمن الاليل: مقدمة الاليل، والهـدف منـه، ونبذة مختصرة عن الاستراتيجية المقترحة القائمـة على الامـج بين محطات التعلم ودورة التعلم السباعية، والأهداف العامـة للوحدة، والمدة الزمنية اللازمة لتدريس الوحدة، ووسـائل الوحدة وأنشطتها، وطرق التقويم المتبعة، ثم خطة السير في كل درس حسب مراحل الاستراتيجية المقترحة. ه. ولضبط الوحدة ودليل المعلم تم عرضهم على السادة المحكمين للتعرف على مدى تحقق دئ الأهداف التي وضـعوا من أجلها، ومـدى التناستق بين مراحل الاستراتيجية المقترحسة، ومدى مناسبة وملاعمة الأنشطة لطلاب الصف الأول الثانوى. وتم تعديل الوحدة ودليل المعلم وفق آرائهم وأصبحوا في صورتهم النهائية(*)(*). ومن ثم تم الإجابة عن السؤال الثالث من أسئلة البحث وهو وهو "مـا صورة وحدة معاد صياغتها في ضـوء الاستراتيجية المقترحة القائمسة على الـمـج بـين دورة التعلم السباعية ومحطات التعلم؟.

$$
\text { ( * * ) ملحق رقم (广) وحدة الأنشطة الاقتصادية معاد صباغتها. }
$$


رابعـاً: قيــاس أثر الاستراتيجية المقترحة على تقمية مهـارات التحقيق الجفرافى ومستوى

التمثيل العقلى للعقلومات، و تم ذلك من خلال:

l. إعداد اختبار مهارات التحقيق الجفرافى لطلاب الصف الأول الثانوى :

تم إعداد اختبار مهارات التحقيق الجغرافى وفقاً للخطوات التالية:

الهـاف مـن الاختبار : تمثل في التعرف على مـدى نمو مهارات التحقيق الجغرافى لطلاب الصف الأول الثانوى.

تحديد شكل الاختبار ودرجاتهاه: تمـت مراجعة بعض الدراسـات السـابقة التـي أعدت مقاييس

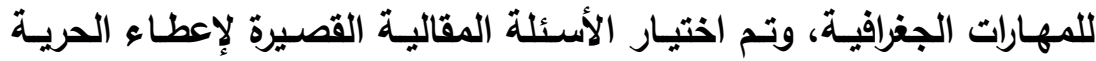

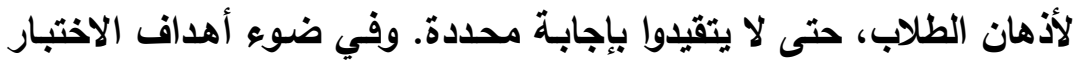

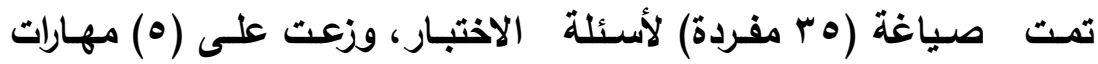
للتحقيق الجغرافى. وتم استخدام الرسوم البيانية والصور والمقالات والجداول والإحصـائيات والخرائط والأخبار في اعداد مفردات الاختبار . كمـا تم تحديد درجة وإحدة للإجابة الصحيحة على كل مفردة. الخصـائص السـيكومترية لاختبـار مهـارات التحقيـق الجغرافـى: تـم تطبيـق اختبـار مهـارات

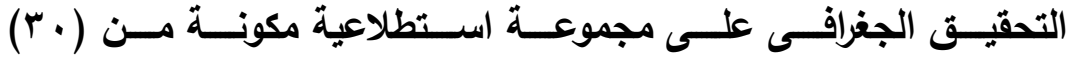

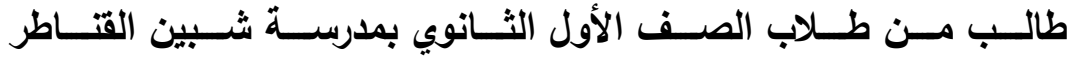
الثانوية بنين، وذلك لحساب صدق وثبات وزمن الاختبار. حساب صدق الاختبار : تم حساب صدق الاختبار عن طريق: صدق الاتساق الاخلي: وتم حسابه من خلال حساب معاملات الارتباط بين المهارات الفرعية واللدرجة الكلية للاختبار والجدول التالى يوضح هذه المعاملات:

\begin{tabular}{|c|c|}
\hline معامل الارتباط بالارجة الكلية & مهارات التحقيق الجغرافى \\
\hline$* * . . V 1$ & تحديد الهيد من التحقيق الجغرافى \\
\hline$* * \cdot . V \mu$ & جمع وتسجيل وتقييم المطلومات \\
\hline$* * . . \mathrm{VV}$ & تمثيل المعلومات الجغرافية وتفسير ها \\
\hline$* * . \wedge 1$ & الإجابة عن أسئلة التحقيق الجغرافى \\
\hline$* * . . \vee q$ & الانعكاس و الاستجابة \\
\hline
\end{tabular}

جدول ( 1 ) يوضح صدق الاتساق الداخلى لاختبار مهارات التحقيق الجغرافى ** دال عند ال ـ. 
يتضح من الجدول السابق أن جميع معاملات الارتباط بين كل مهارة والارجة الكلية دالة

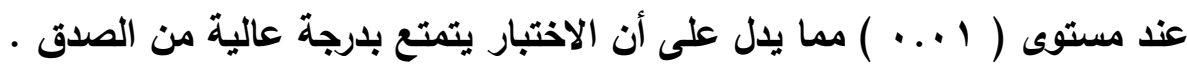

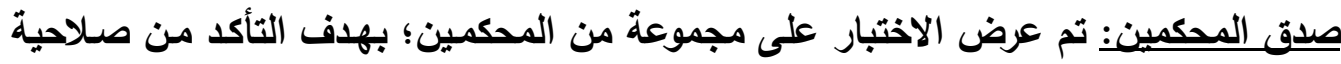

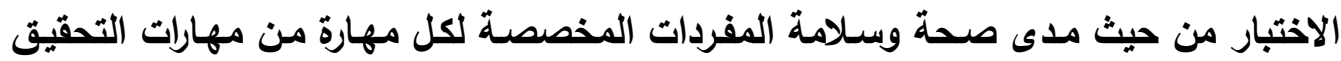

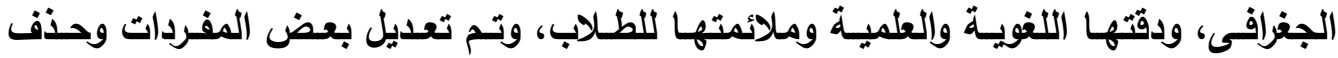
مفردتين بناء على ملاحظات المحكمين ليصبح عدد مفردات الاختبار بr مفردة. حساب ثبات وزمن الاختبار : تم حساب ثبات اختبار مهارات التحقيق الجغرافى بطريقتين هما: طريقة ألفا كرونباخ وطريقة التجزئة النصفية والجدول التالى يوضح معاملات الثبات:

\begin{tabular}{|c|c|c|}
\hline $\begin{array}{l}\text { (التجزئة النصفية } \\
\text { ( سبيرمان براون ) }\end{array}$ & كرونباخ ألفا & مهارات التحقيق الجغرافى \\
\hline$\because V r$ & $\cdot . \mathrm{VV}$ & تحديد الهذف من التحقيق الجغرافى ووضع \\
\hline..$V \cdot$ &.$v 1$ & جمع وتسجيل وتقييم المعلومات \\
\hline. .11 &.$V r$ & تمثيل المعلومات الجغر افية وتفسيرها \\
\hline..$V \cdot$ &.$\vee v$ & الإجابة عن أسئلة التحقيق الجغرافى \\
\hline$\because V Y$ &. .17 & الانعكاس والاستجابة \\
\hline.$\wedge \varepsilon$ & $\cdot . \wedge T$ & المقياس ككل \\
\hline
\end{tabular}

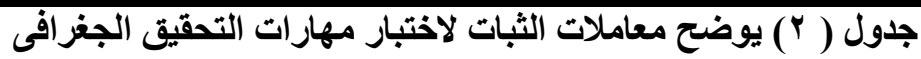

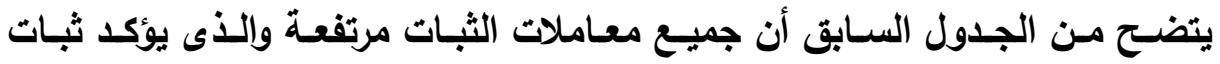
المقياس. حساب زمن الاختبار : حدد زمن الاختبار بـ ( • ـ دقيقة) كمتوسط الفرق الزمنس لإجابـة أول

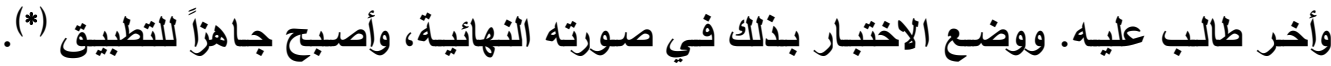

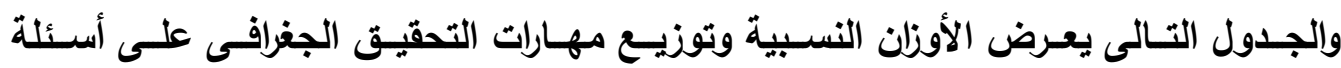


استراتيجية مقترحة قائمة على الدمج بين دورة التعلم السباعية ومحطات التعلم .

\begin{tabular}{|c|c|c|c|c|}
\hline المئوبة النسبة & عدد المفردات & مفردات الاختبار & مهارات التحقيق الجغزافى & r \\
\hline$\% Y \varepsilon . Y$ & $\wedge$ & $\begin{array}{l}6)_{616068} \\
r q 6 r V 6 r 46 r 0\end{array}$ & تحديد الهدف من التحقيق & 1 \\
\hline$\%$ \% & $\Lambda$ & $\begin{array}{l}619696 V 6 r 67 \\
Y E 6 Y 16 Y .\end{array}$ & جمع وتسجيل وتقينيم & $r$ \\
\hline$\%$ \% & $\Lambda$ & 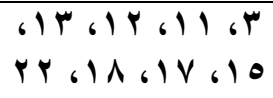 & تمثيل المعلومات الجغر افية & $\mu$ \\
\hline$\% 1 Y .1 Y$ & $\varepsilon$ & 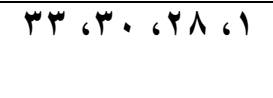 & الإجابة عن أسئلة التحقيق & $\varepsilon$ \\
\hline$\% 10.10$ & 0 & 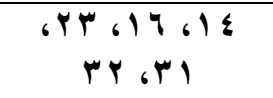 & الانعكاس والاستجابة & 0 \\
\hline$\% 1 \ldots$ & $r \mu$ & ختبار & العدد الكلى لمفردات & \\
\hline
\end{tabular}

r. اعداد مقياس التمثيل العقلى للمعلومات لطالاب الصف الأول الثانوى :

هدف المقبـاس: تمثل فى فياس مستوى التمثيـل العقلى للمعلومـات لـى طلاب الصف الأول الثانوى من خلال استجابتهم على عبارات المقياس، وتحديد مدى تأثير الاستراتيجية المقترحة في رفع مستوى التمثيل العقلى للمعلومات.

أبعاد المقباس: لتحديد أبعاد المقياس تم الاطلاع على عدد من المقاييس الخاصة بالتمثيل العقلى للمعلومات، وتم التوصل إلى سبعة أبعاد للمقياس، وهم (الاحتفاظ، المعنى، الاثتثاق، التوليف، تعدد صيغ التمثيل العقلى، المرونة العقلية المعرفية، دينامية التمثيل المعرفى). صباغة مفردات المقباس وتحدبد درجاته: تمث صياغة مجموعة من العبارات تحت كل بعد من الأبعاد، وأمام كل عبارة ويوجد ثلاثنة اختيارات أمام كل عبارة وهم (تنطبق، تنطبق إلى حد ما، لا تتطبق)، وقد تحددت عبارات المقياس فى (ه0) عبارة، ويضع الطالب علامة (ل (لمام العبارة التي تثتاسب معه.

وتم تحديد درجات المقياس بإعطاء ب تقديرات للاستجابات وهى كتالى (تنطبق ب، تنطبق إلى حد ما ץ، لا تتطبق 1) ومن ثم تعد أعلى درجة يمكن أن يحصل عليها الطالب هي ( 1 ( 1 ) وأقل درجة هي (00) 
الاراسة الاستطلاعبة للمقباس:

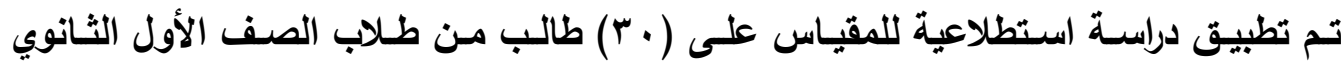
بمدرسة شبين القتاطر الثانوية بنين، وذلك لحساب ثبات الاختبار وصدقه وزمنه. ثبات المقياس: تم حساب ثبات مقياس التمثيل العقلى للمعلومات بطريقتين هما: طريقة ألفا كرونباخ وطريقة التجزئة النصفية والجدول التالى يوضح معاملات الثبات:

\begin{tabular}{|c|c|c|}
\hline (التجزئة النصفية & كرونباخ ألفا & البعد \\
\hline.$\vee v 0$ &.$\wedge r$ & الاحتفاظ \\
\hline .09 & $. \wedge \leq$ & المعنى \\
\hline .09 &.$\wedge \wedge$ & الاشتقاق \\
\hline..$\wedge 1$ & .09 & التوليف \\
\hline..$\vee \wedge$ &..$\wedge 7$ & تعدد صيغ التمثيل العقلى \\
\hline.$\wedge 1$ &.$\wedge 0$ & المرونة العقلية المعرفية \\
\hline. .10 &.$\wedge$. & دينامية التمثيل المعرفى \\
\hline .91 & $.9 r$ & المقياس ككل \\
\hline
\end{tabular}

جدول ( ؛ ) يوضح معاملات الثبات لمقياس التمثيل العقلى للمعلومات

يتضح من الجدول السابق أن جميع معاملات الثبات مرتفعة والذي يؤكد ثبات المقياس.

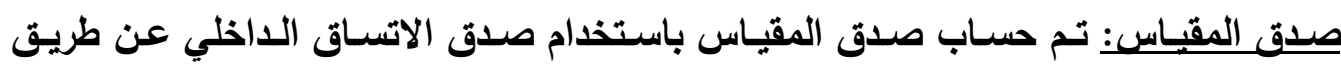
حساب معاملات الارتباط بين المهارات الفرعية والدرجة الكلية للمقياس والجدول التالى يوضـح

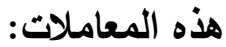

\begin{tabular}{|c|c|}
\hline معامل الارتباط بالدرجة الكلية & أبعاد المقياس \\
\hline$* * \cdot . \vee \neg$ & الاحتفاظ \\
\hline$* * . . \vee 0$ & المعنى \\
\hline$* * \cdot . \wedge 1$ & الاشتقاق \\
\hline$* * \cdot . \wedge 7$ & التوليف \\
\hline$* * \cdot . \wedge r$ & تعدد صيخ التمثيل العقلى \\
\hline$* * \cdot . \wedge \theta$ & المرونة العقلية المعرفية \\
\hline$* * \cdot . \vee \wedge$ & دينامية التمثيل المعرفى \\
\hline
\end{tabular}

جلول ( • ) يوضح صدق الاتساق الداخلى لمقياس التمثيل العقلى للمعلومات

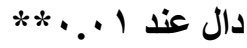


يتضح من الجدول السابق جميع معاملات الارتباط بين كل بعد و الدرجة الكلية دالة عند

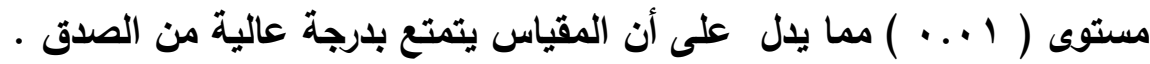
كما حدد زمن المقياس بـ ( • دقيقة) كمتوسط الفرق الزمني لإجابة أول وأخر طالب عليه.

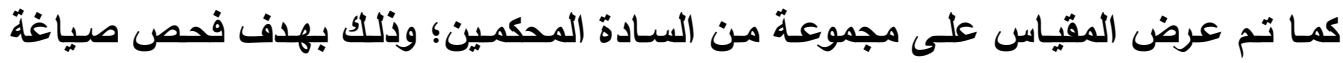
عبارات المقياس وإبداء الرأي في مدى تمثيل العبارات لأبعاد المقياس، وقد أبدى المحكمون بعض الملاحظات وتم تعديل المقياس في ضوء آرائهم ليصبح المقياس في صورته النهائية وجـاهز للتطبيق (*). والجدول التالى يوضـح الأوزلن النسبية وتوزيـع عبـارات مقيـاس التمثيل

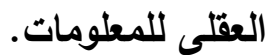

\begin{tabular}{|c|c|c|c|c|}
\hline المئوية & العبار ات & عبار ات المقياس & أبعاد المقياس & r \\
\hline$\% 1 \leq .0$ & $\Lambda$ & $\Lambda_{6} V^{\prime} Y_{6} 0_{6} \leqslant Y_{6} Y_{6} 1$ & البعد الأول: الاحتفاظ & 1 \\
\hline$\%$ & $\Lambda$ & $61061 \leq 61 \% 61 \% 61161 \cdot 69$ & البعد الثانى: المعنى & r \\
\hline$\% 1 \leq .0$ & $\Lambda$ & 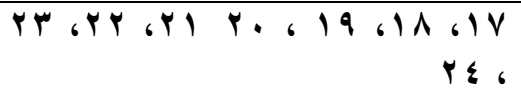 & البعد الثالث: الاشتقاق & $\mu$ \\
\hline$\% 1 \cdot .9 \cdot$ & 7 & 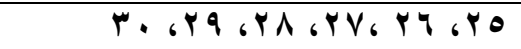 & البعد الرابع: التوليف & $\varepsilon$ \\
\hline \% \% & Ir & 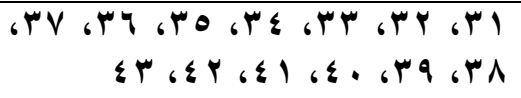 & البمثديل الخامس: العقلى: تعدد صيغ & 0 \\
\hline$\%$ Y Y.VY & $\mathrm{V}$ & $0,6 \leqslant 9$ ، $\leqslant \wedge$ ، $\leqslant \vee$ ، $\leqslant 7$ ، $\leqslant 0$ ، $\leqslant \leqslant$ & البقلية المعرفية السـادس: المرونـة & 7 \\
\hline$\% 9.9$ & $\bullet$ & 00 ، $0 \leq 60 r_{6} 0 r_{6} 01$ & التمثيلـ المعرفـى السـع: ديناميــة & V \\
\hline$\% 1 \ldots$ & 00 & & \multicolumn{2}{|c|}{ العدد الكلى لعبار ات المقياس } \\
\hline
\end{tabular}

جدول(†) الأوزان النسبية وتوزيع العبارات على أبعاد مقياس التمثيل العقلى للمعلومات. 


\section{تجربة البحث (نتائجها -تقفسيرها )}

للتأكد من أثر الاستراتيجية المقترحة القائمسة على الدمج بين دورة التعلم السباعية ومحطات التعلم فى تنمية مهارات التحقيق الجغرافى والتمثيل العقلى للمعلومـات، تم إجراء التطبيق الميداني لأدوات البحث، وذلك من خلال: التصمييم التجريبي للبحث:

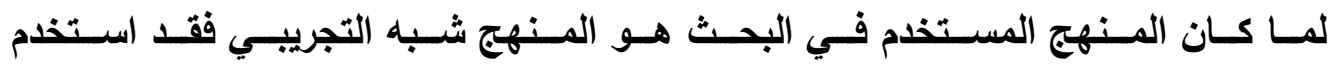

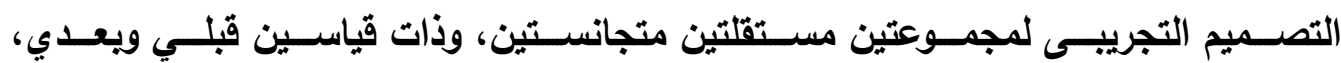
إحداهما تجريبية والأخرى ضابطة؛ ذلك لأنها تناسب طبيعية متغيرات البحث.

\section{الاساليب الإحصائية المستخلمة:}

Statistical تم إدخال البيانات، عن طريق استخدام الرزمـة الإحصائية للعلوم الإنسـانية (Package For The Social Sciences والحصول على النتائج وقت استعملت الأساليب الإحصائية التالية:

$$
\begin{aligned}
& \text { - اختبار" ت"(t.test) للعينات المستقلة. } \\
& \text { - اختبار" ت"(t.test) للعينات المرتبطة. }
\end{aligned}
$$

اختيـار محموعة البحث: تم اختيار ، ^ طالبة من طالبات الصف الأول الثانوى بمدرسـة شبين القناطر الثانوية بنات (حيث محل سكن الباحثة)، وتقسيمهم مجموعتين، المجموعة التجريبيـة شـملت ( • ؛ ) طالبـة وذلـك لتطبيـق الوحـدة المعـاد صـياغتها بالاسـتراتيجية المقترحة، والمجموعة الضابطة ( • ؛ ) طالبة وقد درسوا الوحدة بالطريقة التقليدية.

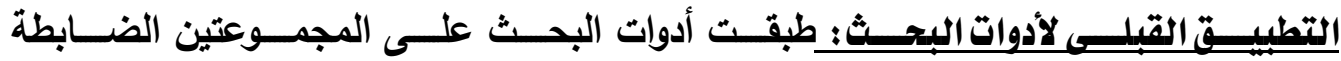

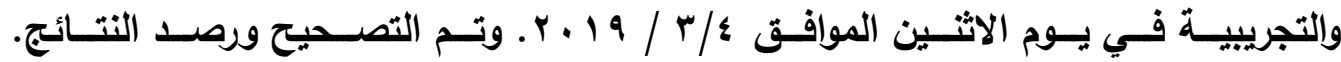
وتـم حسـاب التكـافؤ بـين أفـراد المجموعـة التجريبيـة والمجموعـة الضــابطة فـى اختبـار

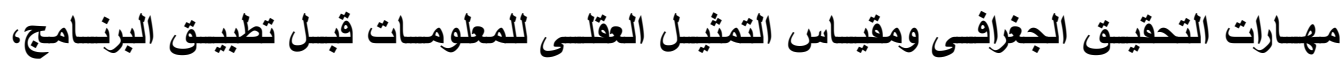
وذلــك بتطبيـق اختبـار (ت) لالالــة الفـروق بـين مجمـوعتين مسـتقلتين والجـدول التـالي يوضح ما تم التوصل إليه من نتائج: 


\begin{tabular}{|c|c|c|c|c|c|c|}
\hline مستوى اللالالة & $ت$ & $\varepsilon$ & r & ن & المجموعة & والمقياس \\
\hline \multirow[t]{2}{*}{ غير دالة إحصائياً } & \multirow[t]{2}{*}{$\because 9}$. & $r . r$ & $1 \% . \varepsilon$ & $\varepsilon$ & ضابطة & \multirow{2}{*}{ التبار مهارات الجنقيق } \\
\hline & & r.\&1 & IY.Vo & «. & تجريبية & \\
\hline \multirow[t]{2}{*}{ غير دالة إحصائياً } & \multirow[t]{2}{*}{$\because O r$} & $0 . \wedge r$ & 71.04 & $\varepsilon$ & ضابطة & \multirow{2}{*}{ لعقلي للمعلوماتيلت } \\
\hline & & $0.1 \mathrm{~V}$ & א. & $\varepsilon$. & تجريبية & \\
\hline
\end{tabular}

$$
\text { جذول (V) نتائج تحليل القياس القبلي لأدوات البحثُ على المجموعتين }
$$

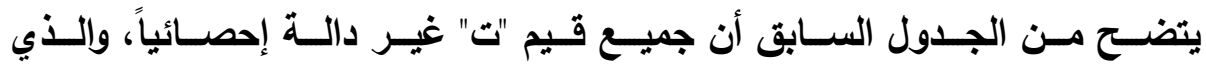

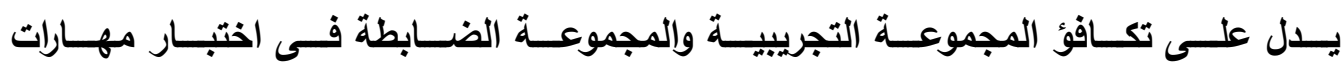
التحقيق الجغرافى ومقياس التمثيل العقلى للمعلومات.

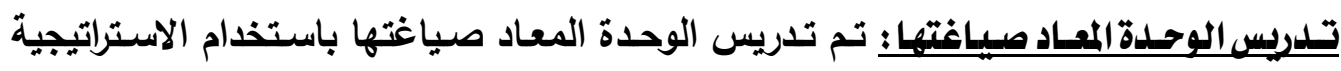
المقترحة القائمة على الدمج بين دورة التعلم السباعية ومحطات التعلم للمجموعة التجريبية

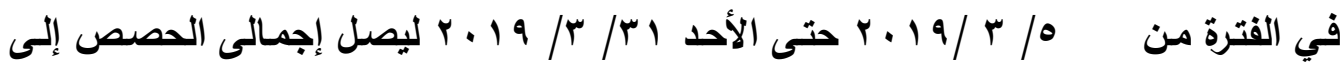
(9 ) حصص. في حين تدرس المجموعة الضابطة الوحدة بالطريقة التقليدية.

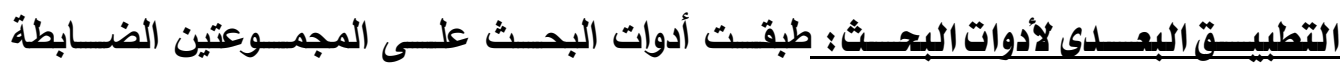
والتجريبية في يوم الثلاثاء الموافق r/ / / 9 / 1 ـ r. وتم التصحيح ورصد النتائج.

\section{تخليل النتائج وتقسيرها:}

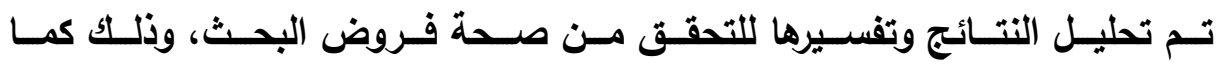

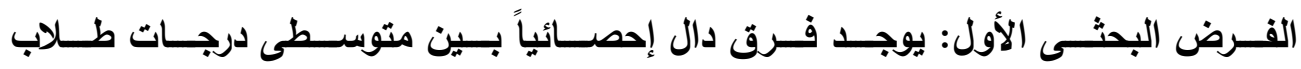

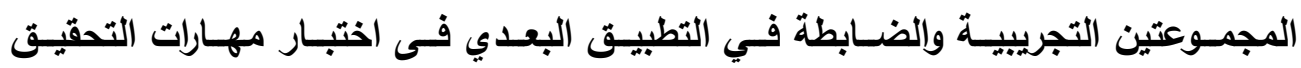
الجغرافى واللارجة الكلية لصالح المجموعة التجريبية.

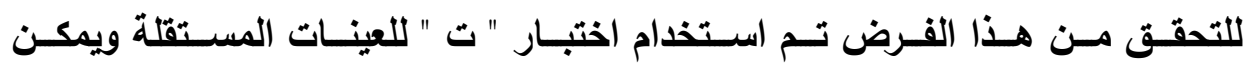
عرض النتائج من خلال الجدول التالى: 
استراتيجية مقترحة قائمة على الدمج بين دورة التعلم السباعية ومحطات التعلم .

\begin{tabular}{|c|c|c|c|c|c|c|c|c|}
\hline التأثير & مربع & مستوى الدلاثة & ت & $\varepsilon$ & r & $\dot{ن}$ & القياس & 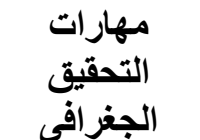 \\
\hline \multirow[t]{2}{*}{ كبيز } & \multirow[t]{2}{*}{$.0 \leqslant$} & \multirow{2}{*}{ عند إلدصائياً } & \multirow[t]{2}{*}{$19.5 \leq$} & 1 & r.7o & $\varepsilon$. & ضابطة & \multirow{2}{*}{ 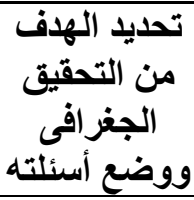 } \\
\hline & & & &. .74 & V.Yo & $\varepsilon$. & تجريبية & \\
\hline \multirow[t]{2}{*}{ كبيز } & \multirow[t]{2}{*}{$\because \leqslant \Lambda$} & \multirow{2}{*}{ 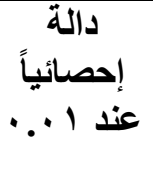 } & \multirow[t]{2}{*}{$17 . \cdot r$} & $1 . \cdot r$ & $r . \varepsilon r$ & $\varepsilon$. & ضابطة & \multirow{2}{*}{ جمع وتسجيل } \\
\hline & & & &. .9 & 7.9 & $\varepsilon$. & تجريبية & \\
\hline \multirow[t]{2}{*}{ كبيز } & \multirow[t]{2}{*}{ 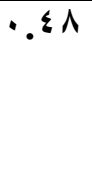 } & \multirow{2}{*}{ 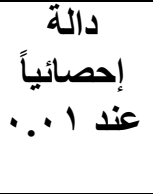 } & \multirow[t]{2}{*}{17.71} & 1.11 & $r .0 \Lambda$ & $\varepsilon$. & ضابطة & \multirow{2}{*}{ المعلومثات } \\
\hline & & & &. .81 & $V .0$ & $\varepsilon$. & تجريبية & \\
\hline \multirow[t]{2}{*}{ كبيز } & \multirow[t]{2}{*}{.$r v$} & \multirow{2}{*}{ 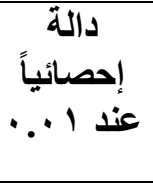 } & \multirow[t]{2}{*}{1.9.} & $1 . r r$ & $r . r$ & $\varepsilon$. & ضابطة & \multirow{2}{*}{ أسئلة الإبة عنيق } \\
\hline & & & &..$r r$ & $r .90$ & $\varepsilon$. & تجريبية & \\
\hline \multirow[t]{2}{*}{ كبيز } & \multirow[t]{2}{*}{$\because \leqslant 1$} & \multirow{2}{*}{ 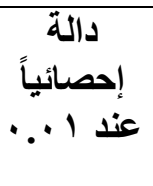 } & \multirow[t]{2}{*}{$1 \cdot . \leqslant 1$} & 1.47 & r. 1 & $\varepsilon$. & ضابطة & \multirow{2}{*}{ والاستعكاس } \\
\hline & & & &. .71 & $\varepsilon . \leqslant 0$ & $\varepsilon$. & تجريبية & \\
\hline \multirow[t]{2}{*}{ كبيز } & \multirow[t]{2}{*}{.01} & \multirow{2}{*}{ عالة إئياً } & \multirow[t]{2}{*}{$r \cdot .71$} & r.VA & $1 \varepsilon .90$ & $\varepsilon$. & ضابطة & \multirow{2}{*}{ الدرجة الكلية } \\
\hline & & & & $r . \leqslant r$ & rq. & $\varepsilon$. & تجريبية & \\
\hline
\end{tabular}

جدول ( ^) يوضح الأعداد و المتوسطات و الانحرافات المعيارية و قيمة " ت " و دلالتها فى مهارات التحقيق

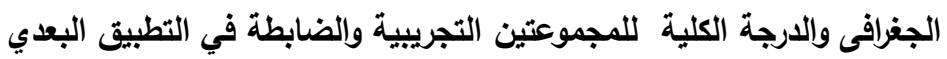

يتضـح مـن الجدول السـابق أنـه توجد فروق ذات دلالـة إحصـائية بـين المجموعة الضـابطة والمجموعة التجريبية في اختبار مهاراث التحقيق الجغرافى، وكان متوسط مهارة تحديد التهدف من التحقيق الجغرافحى ووضـع أسئلته لصـالح المجموعة التجريبية حيث كانت قيمـة " ت " = ع r . 1 و و هى دالة إحصائياً عند مستوى I ... ، كما يتضح من الجدول السـابق أنهل توجد فروق ذات دلالة إحصائية بين المجموعة الضـابطة و المجموعة التجريبية فى متوسط مهارة جمـع وتسـيل وتقيـيم المعلومـات لصـالح المجموعـة التجريبيـة حيـث كاتـت قيمـة " ت " = 


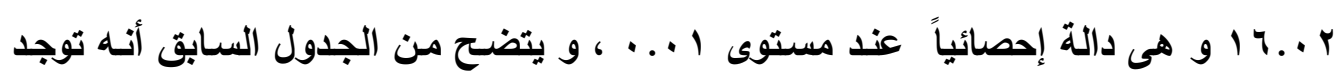

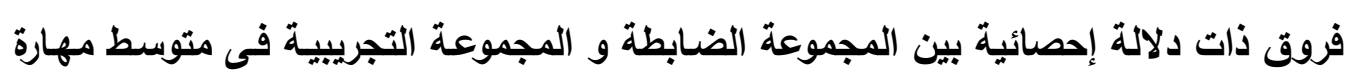

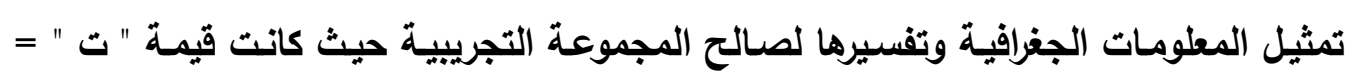

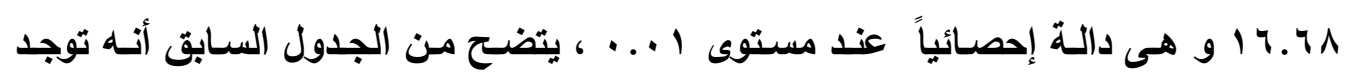

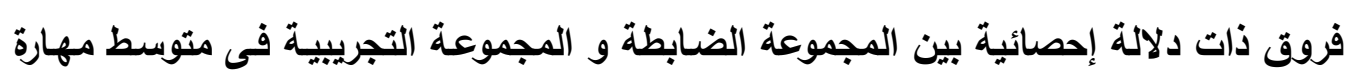
الإجابة عن أسئلة التحقيق الجغرافى لصالح المجموعة التجريبية حيث كانت قيمة " ت ت " =

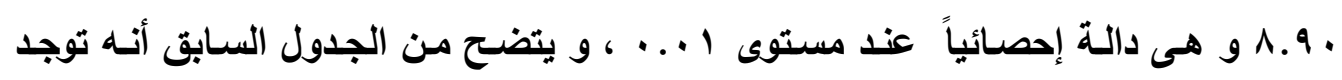
فروق ذات دلالة إحصائية بين المجموعة الضابطة و المجموعة التجريبية في متوسط مهارة

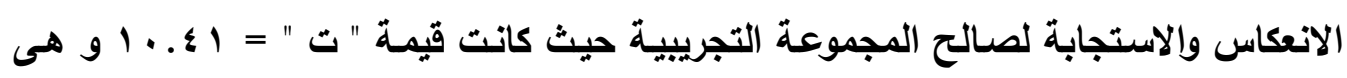

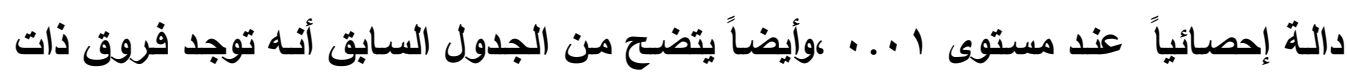

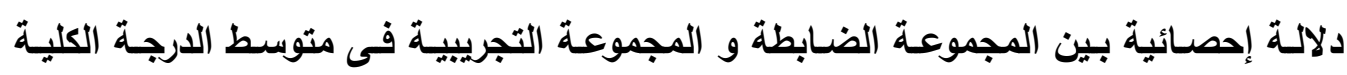

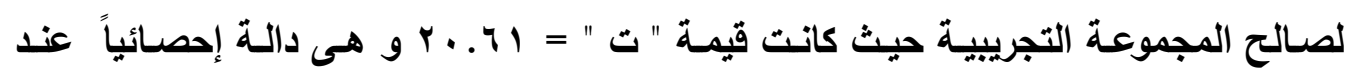

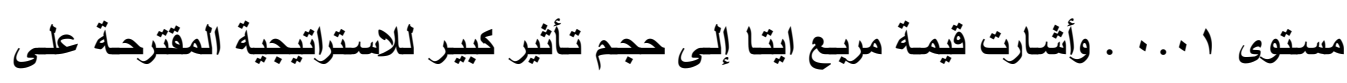
تنمية مهارات التحقيق الجغرافى. ويمكن توضيح هذه النتيجة من خلال الثكل التالى :

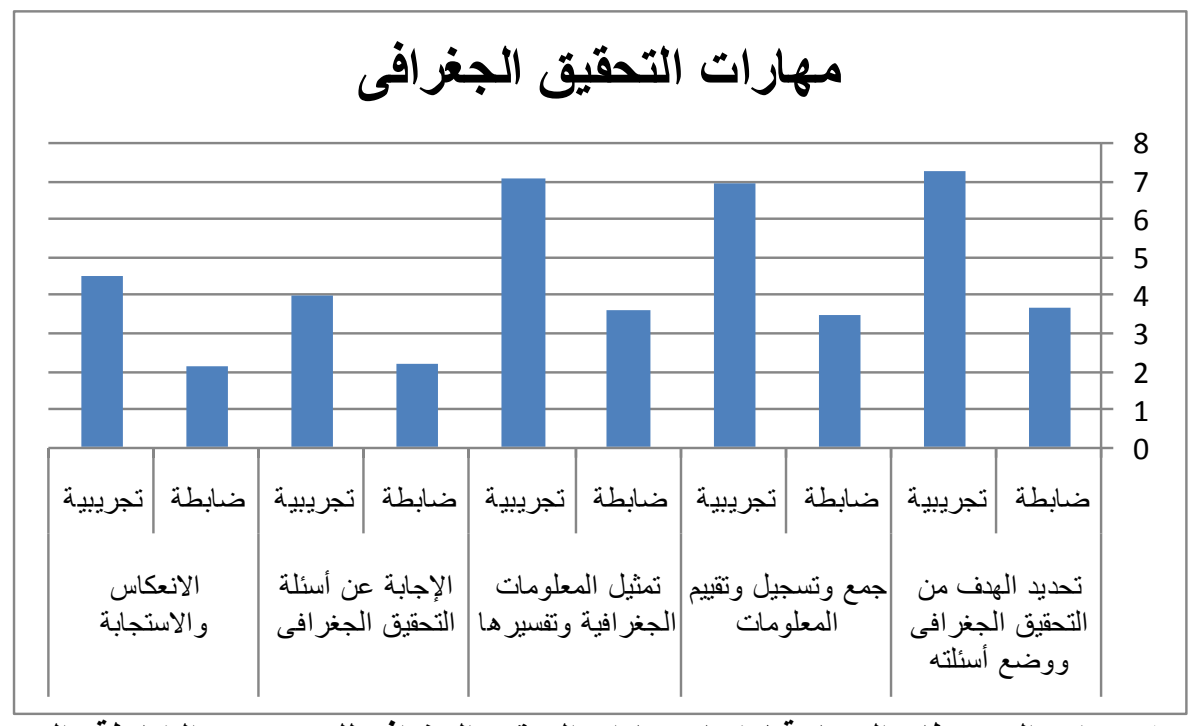

شكل( ' ) يوضح المتوسطات الحسابية لاختبار مهارات التحقيق الجغرافى للمجموعتين الضابطة والتجريبية 


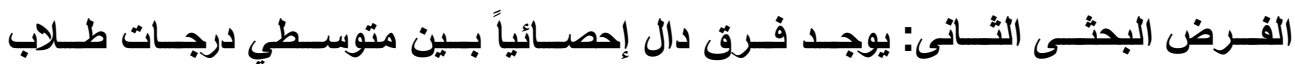
المجموعـة التجريبيـة فـى التطبيقـين القبالـى والبعـدى فـى اختبـار مهـــارات التحقيـق الجغرافى ككل وفى كل مهارة على حده وذلك لصالح التطبيق البعدى. للتحقق من هذا الفرض تم استخدام اختبار " ت " للعينات المرتبطة ويمكن عرض النتائج من خلال الجدول التالى:

\begin{tabular}{|c|c|c|c|c|c|c|c|c|}
\hline التأثجير & إيتا & مستوى الدلالة & ت & $\varepsilon$ & p & ن & القياس & البعد \\
\hline \multirow[t]{2}{*}{ كبير } & \multirow[t]{2}{*}{$\because 7 \leqslant$} & \multirow[t]{2}{*}{ دالة إحصائياً عند } & \multirow{2}{*}{$r \leqslant . V \leqslant$} & .91 & r.ro & $\varepsilon$. & قبلى & \multirow{2}{*}{ تحن التحقيق الهـف } \\
\hline & & & & r & V.YO & $\varepsilon$. & بعدى & \\
\hline \multirow[t]{2}{*}{ كبير } & \multirow[t]{2}{*}{$\because 0 \leqslant$} & \multirow{2}{*}{ دالة إحصائياً عند } & \multirow{2}{*}{$19.0 \leq$} & $1.1 \varepsilon$ & r.. 1 & $\varepsilon$. & قبلى & \multirow{2}{*}{ وتشجيل وتمبيل } \\
\hline & & & & $\cdot .9$ & 7.9 & $\varepsilon$. & بعدى & \\
\hline \multirow[t]{2}{*}{ كبير } & \multirow[t]{2}{*}{.94} & \multirow[t]{2}{*}{ دالة إحصائياً عند } & \multirow{2}{*}{$r$ r.s } & 1.0 & $r . \cdot 1$ & $\varepsilon$. & قبلى & \multirow{2}{*}{ المعلومات } \\
\hline & & & &.$v_{1}$ & $v . .0$ & $\varepsilon$. & بعدى & \\
\hline \multirow[t]{2}{*}{ كبيز } & \multirow[t]{2}{*}{.01} & \multirow{2}{*}{ دالة إحصائياً عند } & \multirow{2}{*}{ r. IV } &.$V \varepsilon$ & 1.70 & $\varepsilon$. & قبلى & \multirow{2}{*}{ الأجئلة التحنة عن الإنفيق } \\
\hline & & & &.$r r$ & $r .90$ & $\varepsilon$. & بعدى & \\
\hline \multirow[t]{2}{*}{ كبير } & \multirow[t]{2}{*}{$\because .0 Y$} & \multirow{2}{*}{ دالة إحصائياً عند } & \multirow{2}{*}{$11 . \leqslant 1$} & $\because V \varepsilon$ & 1.7 & $\varepsilon$. & قبلى & \multirow{2}{*}{ والالنعكاس } \\
\hline & & & & .71 & $\leqslant . \leqslant 0$ & $\varepsilon$. & بعدى & \\
\hline \multirow[t]{2}{*}{ كبيز } & \multirow[t]{2}{*}{$\because \wedge \leqslant$} & \multirow[t]{2}{*}{ دالة إحصائياً عند } & \multirow{2}{*}{$r \varepsilon . \wedge r$} & r.\&1 & IY.Vo & $\varepsilon$. & قبلى & \multirow{2}{*}{ الألية } \\
\hline & & & & $r . \leqslant r$ & rq. & $\varepsilon$. & بعدى & \\
\hline
\end{tabular}

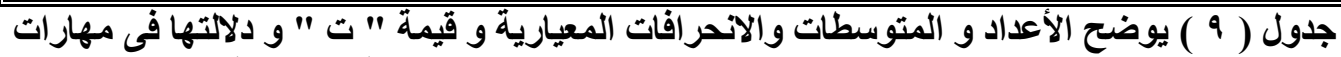

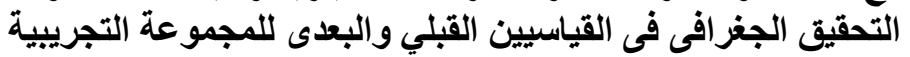




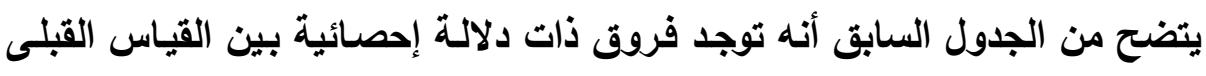
والبعدى للمجموعة التجريبية فى متوسط مهارة تحديد الهدف من التحقيق الجغرافى ووضع فرئ

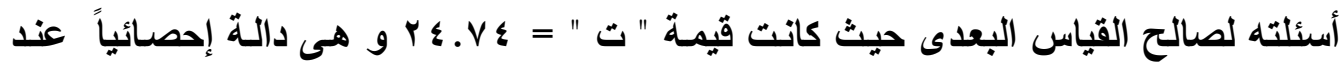
مستوى ا ... ، كما يتضح من الجدول السـابق أنه توجد فروق ذات دلالية إحصائية بين القياس القبلى و البعدى فى متوسط مهارة جمع وتسجيل وتقييم المعلومـات لصالح القياس

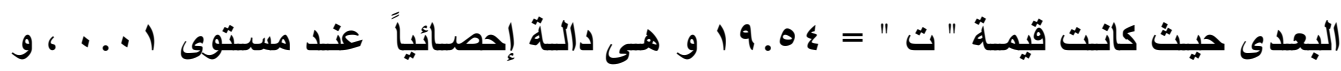

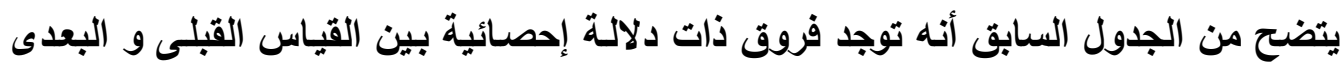

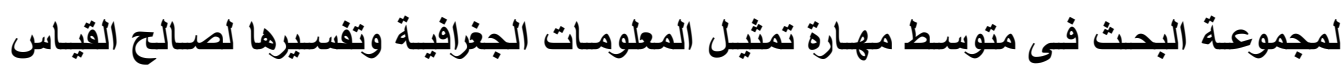

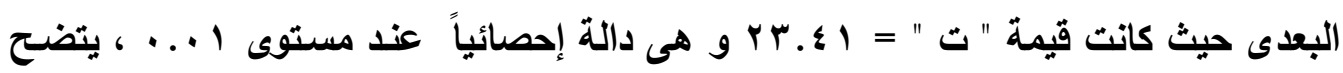

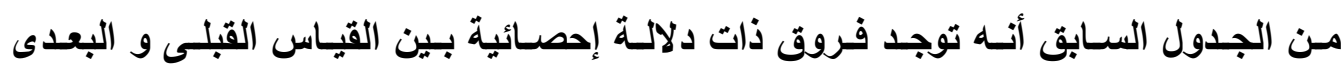

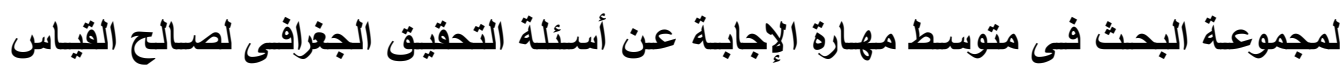

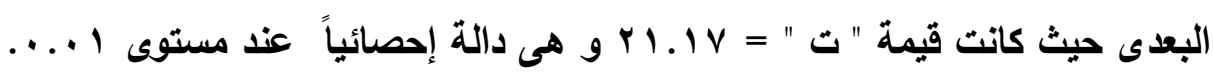

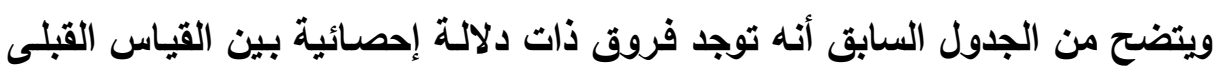

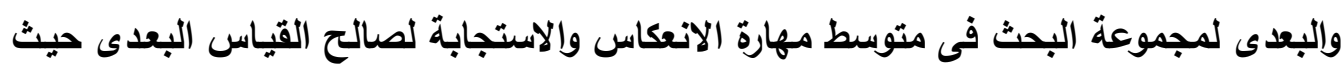

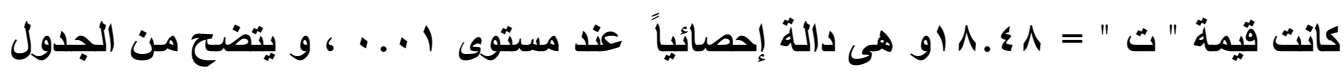

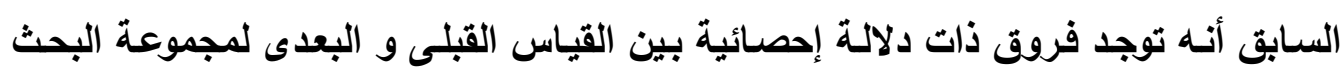

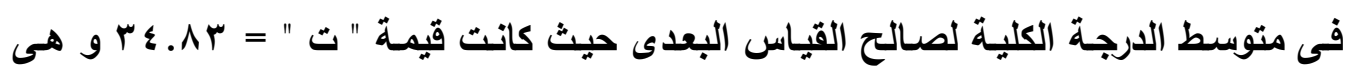

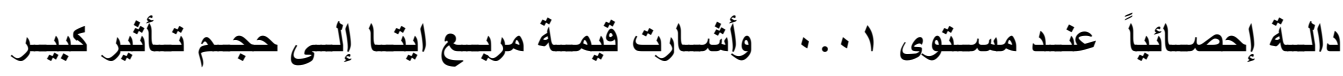

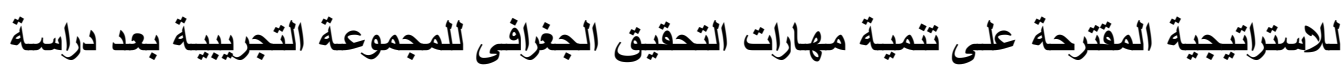
الوحدة. ويمكن توضيح هذه النتيجة من خلال الثكل التالى لئي: 


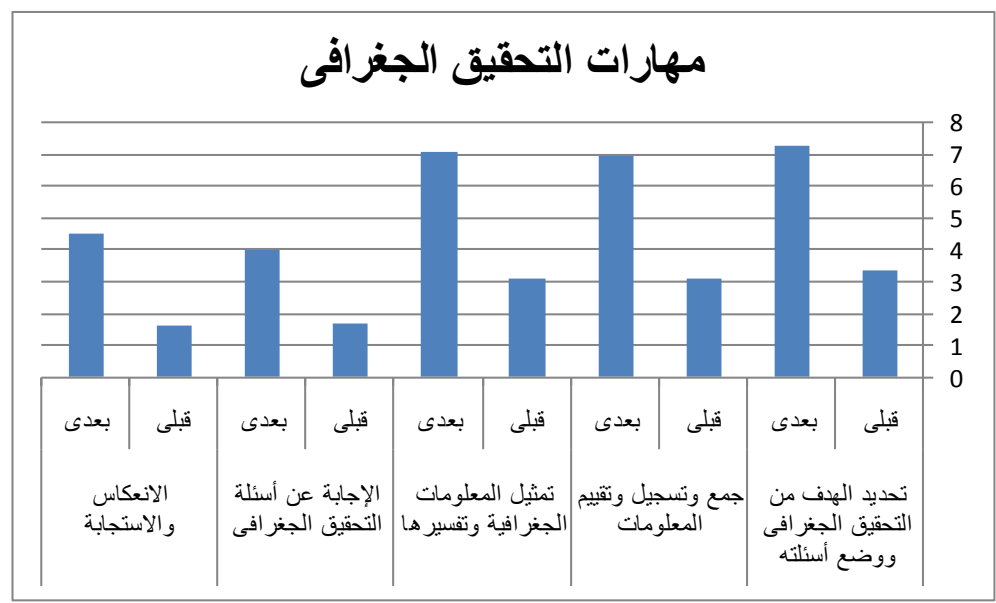

شكل(ץ) يوضح المتوسطات الحسابية لاختبار مهارات التحقيق الجغرافى في القياسين القبلى والبعدى للمجموعة التجريبية

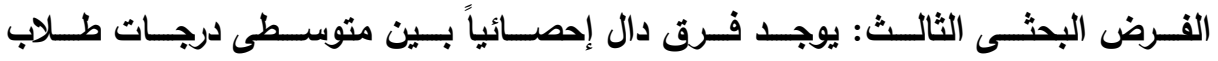

المجمـوعتين التجريبيـة والضـابطة فـي التطبيـق البعـدي فـى مقيـاس التمثبـل العقلى للمعلومـات والارجة الكلية لصالح المجموعة التجريبية.

للتحقق من هذا الفـرض تـم استخدام اختبار " ت " للعينـات المستقلة ويوضـح نتائجها الجدول

\begin{tabular}{|c|c|c|c|c|c|c|c|c|}
\hline التأثير & إيتاب(1) & مستّوى الدلالة & ت & $\varepsilon$ & P & ن & القياس & البعد \\
\hline \multirow[t]{2}{*}{ كبيز } & \multirow[t]{2}{*}{. $.9 \Lambda$} & \multirow{2}{*}{ 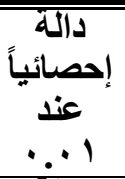 } & \multirow[t]{2}{*}{$70.0 \%$} & 1.19 & 9.8 & $\varepsilon$. & ضابطة & \multirow{2}{*}{ الاحتفاظ } \\
\hline & & & & $.9 \mathrm{~V}$ & Y. & $\varepsilon$. & تجريبية & \\
\hline \multirow[t]{2}{*}{ كبيز } & \multirow[t]{2}{*}{$\bullet \wedge \varepsilon$} & \multirow{2}{*}{ إحصائياً } & \multirow[t]{2}{*}{ 19.19 } & 1.19 & $1 \cdot . \leqslant \mu$ & $\varepsilon$. & ضابطة & \multirow{2}{*}{ المعنى } \\
\hline & & & &.$\wedge \wedge$ & $r$ r.00 & $\varepsilon$. & تجريبية & \\
\hline \multirow[t]{2}{*}{ كبيز } & \multirow[t]{2}{*}{.$\wedge 9$} & \multirow{2}{*}{ إحصائياً } & \multirow[t]{2}{*}{$\varepsilon V .17$} & 1.70 & 9.1 & $\varepsilon$. & ضابطة & \multirow{2}{*}{ الاشتقاق } \\
\hline & & & &..$\vee \wedge$ & $r r . \varepsilon r$ & $\varepsilon$. & تجريبية & \\
\hline \multirow[t]{2}{*}{ كبيز } & \multirow[t]{2}{*}{$\cdot \wedge 1$} & \multirow{2}{*}{ إحصائياً: } & \multirow[t]{2}{*}{ ro.vV } & 1.07 & $\vee .91$ & $\varepsilon$. & ضابطة & \multirow{2}{*}{ التوليف } \\
\hline & & & &..$V$ & $1 V .70$ & $\varepsilon$. & تجريبية & \\
\hline
\end{tabular}

1 - قد بأى كيس

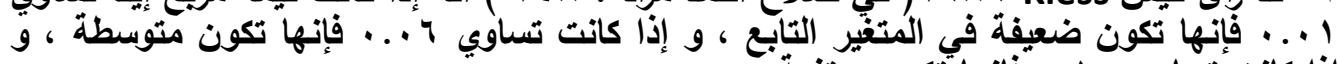

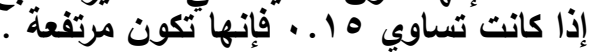


استراتيجية مقترحة قائمة على الدمج بين دورة التعلم السباعية ومحطات التعلم .

\begin{tabular}{|c|c|c|c|c|c|c|c|c|}
\hline \multirow[t]{2}{*}{ كبير } & \multirow[t]{2}{*}{. .99} & \multirow{2}{*}{ إحصائياً } & \multirow[t]{2}{*}{ AY.VA } & 1.20 & $1 \varepsilon .0$ & $\varepsilon$. & ضابطة & \multirow{2}{*}{ تعدد صيخ التمثيل } \\
\hline & & & &. .79 & r.. & $\varepsilon$. & تجريبية & \\
\hline \multirow[t]{2}{*}{ كبيز } & \multirow[t]{2}{*}{.$\wedge 9$} & \multirow{2}{*}{ إحصائياً } & \multirow[t]{2}{*}{ \&V. $4 \varepsilon$} & $1 . r$ & $V .7$ & $\varepsilon$. & ضابطة & \multirow{2}{*}{ المعرونة المعة المقية } \\
\hline & & & & 1.11 & $Y \cdot . \leq 0$ & $\varepsilon$. & تجريبية & \\
\hline \multirow[t]{2}{*}{ كبيز } & \multirow[t]{2}{*}{$\because \wedge 0$} & \multirow{2}{*}{ 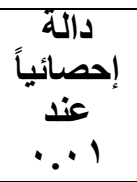 } & \multirow[t]{2}{*}{$\varepsilon \cdot V \cdot$} &. .97 & $0 . V \mu$ & $\varepsilon$. & ضابطة & \multirow{2}{*}{ 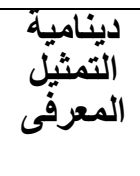 } \\
\hline & & & & .911 & $1 \varepsilon . \diamond 1$ & $\varepsilon$. & تجريبية & \\
\hline \multirow[t]{2}{*}{ كبير } & \multirow[t]{2}{*}{.99} & \multirow{2}{*}{ إحصائياً } & \multirow[t]{2}{*}{$\wedge \wedge . \vee q$} & $7 . \varepsilon V$ & $7 \varepsilon .9 V$ & $\varepsilon$. & ضابطة & \multirow{2}{*}{ الأليةجة } \\
\hline & & & & $r . \leqslant Y$ & 171.90 & $\varepsilon$. & تجريبية & \\
\hline
\end{tabular}

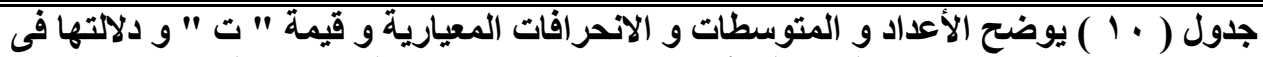

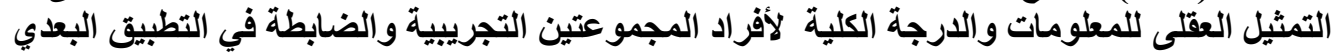

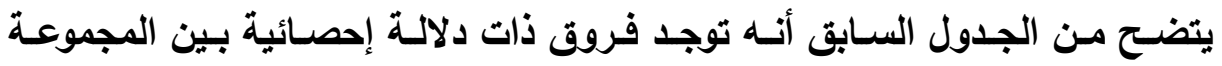
الضابطة و المجموعة التجريبية فى متوسط بعد الاحتفاظ لصالح المجموعة التجريبية حيث

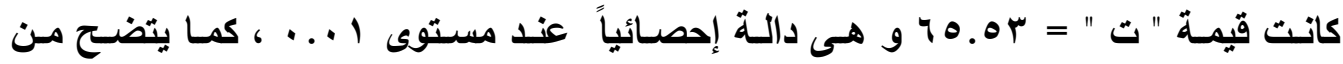
الجدول السـابق أنـه توجد فروق ذات دلالة إحصائية بين المجموعة الضـابطة و المجموعة

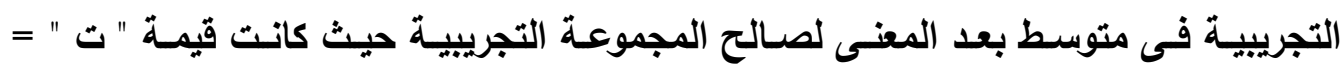

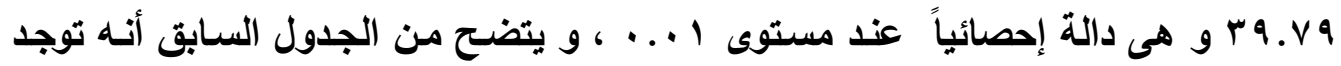

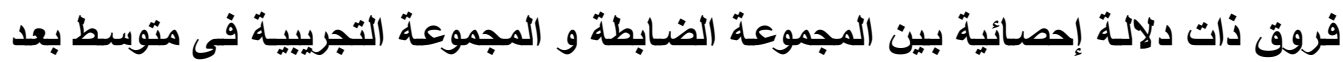

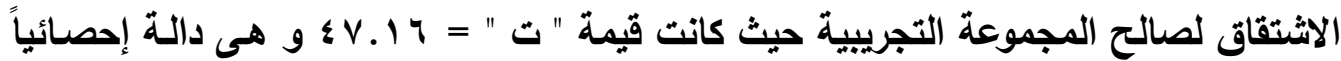

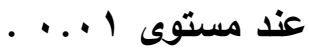
كما يشير الجدول السابق إلى أنه توجد فروق ذات دلالة إحصائية بين المجموعة

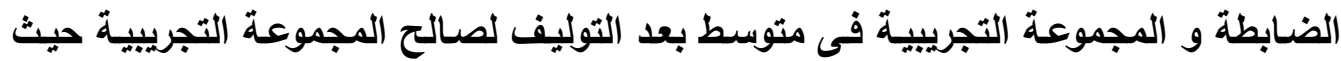

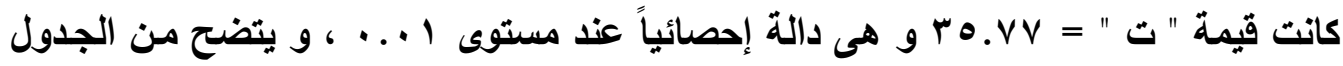
السابق أنه توجد فروق ذات دلالة إحصائية بين المجموعة الضـابطة و المجموعة التجريبية فى متوسط بعد تعدد صيغ التمثيل العقلى لصالح المجموعة التجريبية حيث كانت قيمة " ت " "

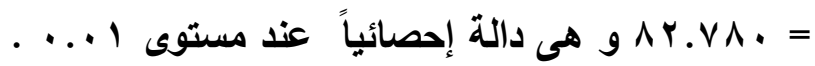




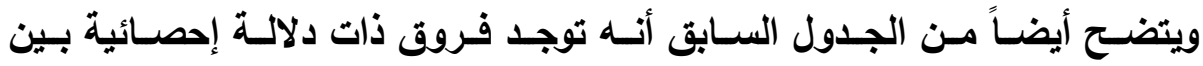
المجموعة الضابطة و المجموعة التجريبية فى متوسط بعد المرونة العقلية المعرفية لصالح

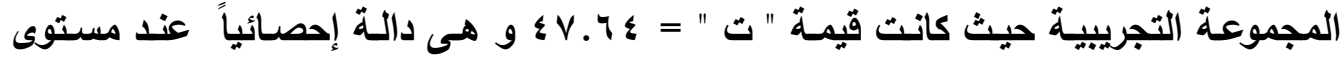

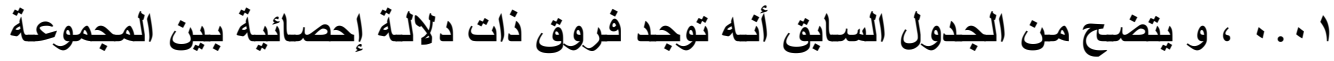

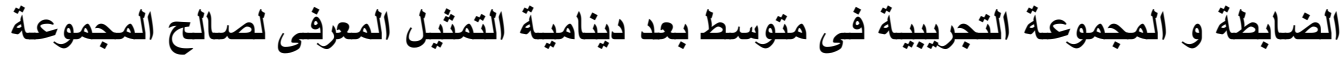

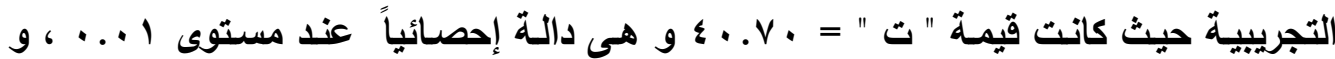
كذلك يتضح من الجدول السابق أنه توجد فروق ذات دلالة إحصائية بين المجموعة الضابطة

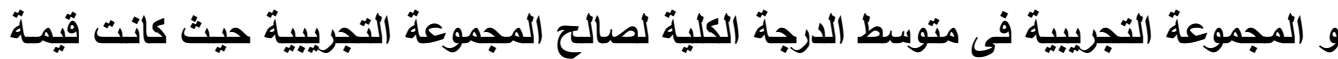

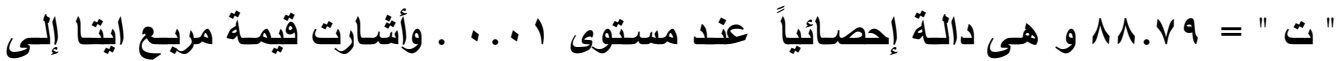
حجم تأثير كبير للاستراتيجية المقترحة على تنمية أبعاد التمثيل العقلى للمعلومـات. ويمكن توضيح هذه النتيجة من خلال الثكل التالى:

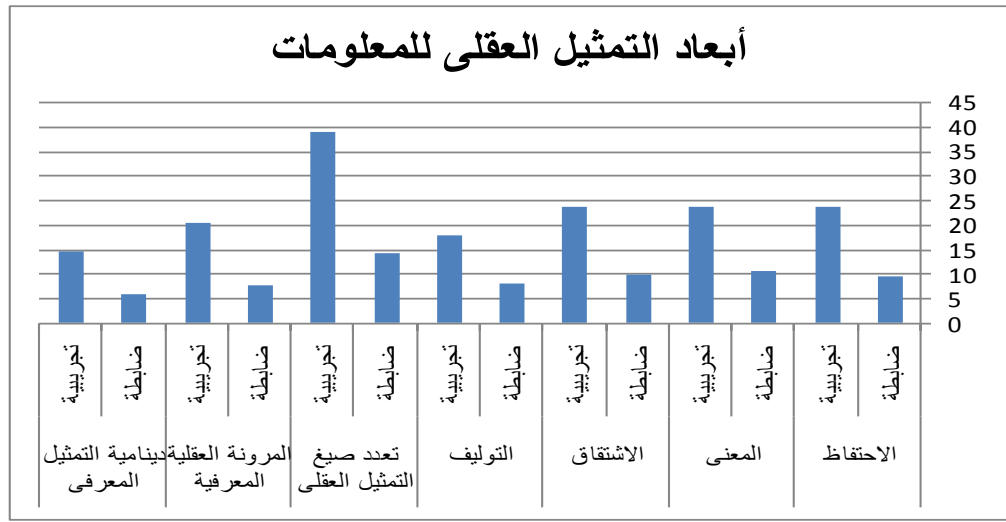

شكل( ") يوضح المتوسطات الحسابية لمقياس التمثيل العقلى للمطومات اللمجمو عتين الضابطة والتجريبية

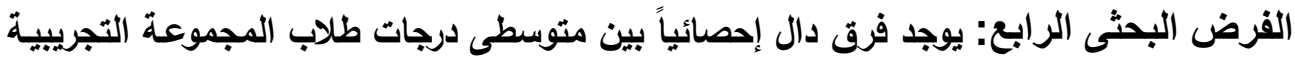

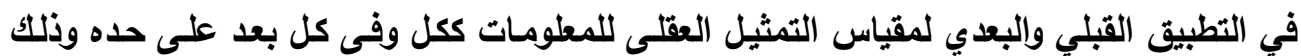
لصالح القياس البعدى. للتحقق من هذا الفرض تم استخام اختبار " ث " للعينات المرتبطة ويمكن عرض ما تم التوصل إليه

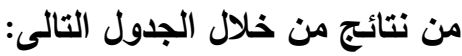




\begin{tabular}{|c|c|c|c|c|c|c|c|c|}
\hline التأثيرّ & مربت & الالاكتية & 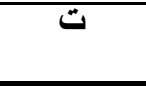 & $\varepsilon$ & $r$ & ن & القياس & البعد \\
\hline \multirow[t]{2}{*}{ كبيز } & \multirow[t]{2}{*}{.99} & \multirow{2}{*}{ عاله إحصائيا } & \multirow{2}{*}{ TV.YY } & 1.97 & $\Lambda . \vee \mu$ & $\varepsilon$. & قتبلى & \multirow{2}{*}{ الاحتفاظ } \\
\hline & & & &. $.7 \mathrm{~V}$ & צ.r & $\varepsilon$. & بعدى & \\
\hline \multirow[t]{2}{*}{ كبيز } & \multirow[t]{2}{*}{.$\wedge \varepsilon$} & \multirow{2}{*}{ عاله إحصائيا } & \multirow{2}{*}{$r q . \wedge q$} & 1.98 & $1 \cdot . v$ & $\varepsilon$. & قبلى & \multirow{2}{*}{ المعنى } \\
\hline & & & &.$\wedge \wedge$ & rr.o0 & $\varepsilon$. & بعدى & \\
\hline \multirow[t]{2}{*}{ كبيز } & \multirow[t]{2}{*}{.90} & \multirow{2}{*}{ عند اله إ.بائيا } & \multirow{2}{*}{$0 . .1 \mathrm{~V}$} & ه $1 .{ }^{1}$ & Q. & $\varepsilon$. & قبلى & \multirow{2}{*}{ الاشتقاق } \\
\hline & & & &.$\vee \vee \Lambda$ & 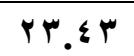 & $\varepsilon$. & بعدى & \\
\hline \multirow[t]{2}{*}{ كبير } & \multirow[t]{2}{*}{.$\Delta r$} & \multirow{2}{*}{ عالة إحصائيا } & \multirow{2}{*}{$\mu v$} & $1 . V \Lambda$ & 1.1 & $\varepsilon$ & قبلى & \multirow{2}{*}{ التوليف } \\
\hline & & & &..$v$ & 18.70 & $\varepsilon$. & بعدى & \\
\hline \multirow[t]{2}{*}{ كبيز } & \multirow[t]{2}{*}{. .99} & \multirow{2}{*}{ عاله إحصائيا } & \multirow{2}{*}{$11 \varepsilon .0 \%$} & 1.1 & 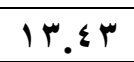 & $\varepsilon$. & قبلى & \multirow{2}{*}{ التمثيل العقبِّمى } \\
\hline & & & &. .79 & r^.V & $\varepsilon$. & بعدى & \\
\hline \multirow[t]{2}{*}{ كبيز } & \multirow[t]{2}{*}{.99} & \multirow{2}{*}{ عاله إحصائيا } & \multirow{2}{*}{$79 . V V$} &. $.7 \mu$ & $v_{.} 1$ & $\varepsilon$. & قبلى & \multirow{2}{*}{ 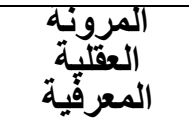 } \\
\hline & & & & 1.11 & $r \cdot . \leqslant 0$ & $\varepsilon$. & بعدى & \\
\hline \multirow[t]{2}{*}{ كبيز } & \multirow[t]{2}{*}{$\because \Lambda V$} & \multirow{2}{*}{ عاله إحصائيا } & \multirow{2}{*}{$\varepsilon \varepsilon .71$} &..$V \varepsilon$ & 0.5 & $\varepsilon$. & قبلى & \multirow{2}{*}{ الثينامثيّة } \\
\hline & & & & .91 & $1 \leqslant .01$ & $\varepsilon$. & بعدى & \\
\hline \multirow[t]{2}{*}{ كبيز } & .99 & داله إحصائيا & 110.00 & $0.1 \mathrm{~V}$ & $7 Y .11$ & $\varepsilon$. & قبلى & الار حة الكلبة \\
\hline & & & & $P . \& Y$ & 171.90 & $\varepsilon$ & بعدى & \\
\hline
\end{tabular}

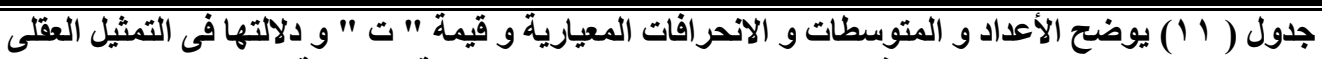

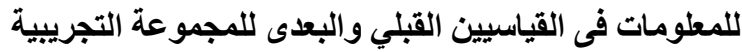

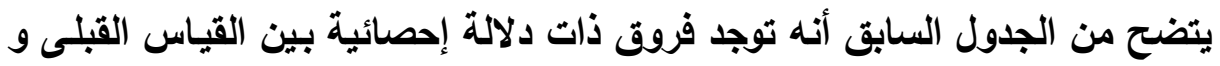

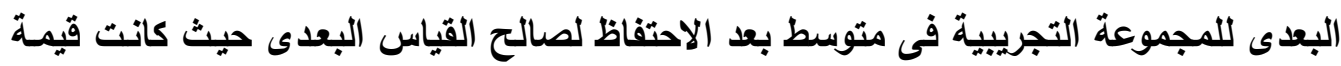

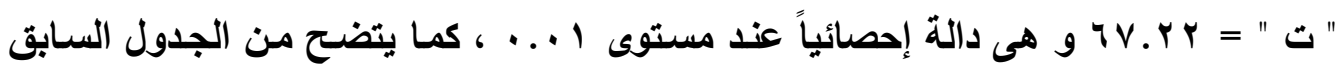
أنـه توجد فروق ذات دلالـة إحصائية بين القياس القبلى و البعدى للمجموعة التجريبية فى دهى

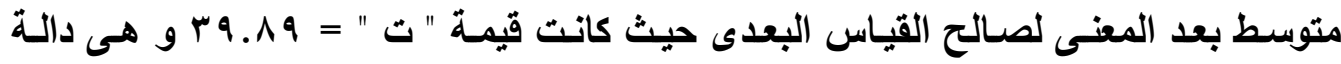

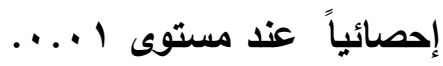

ويشير الجدول السابق إلى أنه توجد فروق ذات دلالة إحصائية بين القياس القبلى و البعدى للمجموعة التجريبية فى متوسط بعد الاثتقاق لصالح القياس البعدى حيث كانت قيمة إلها

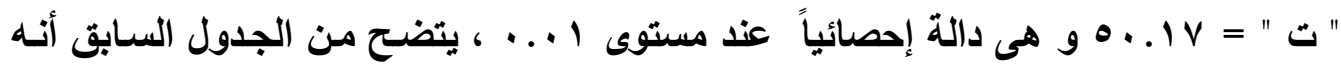

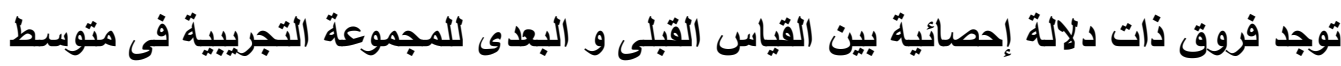

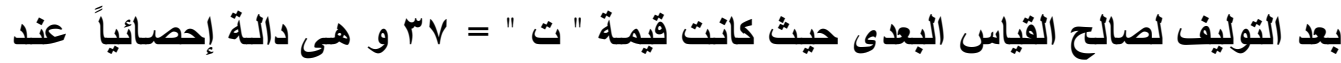




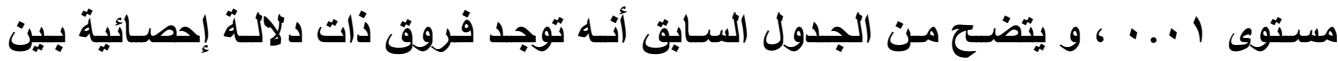
القياس القبلى و البعدى للمجموعـة التجريبية فى متوسط بعد تعدد صيغ التمثيل العقلى

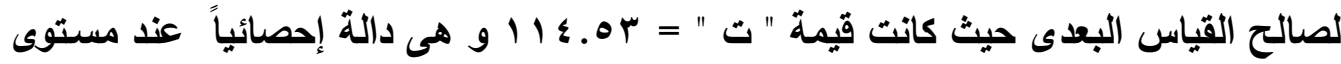

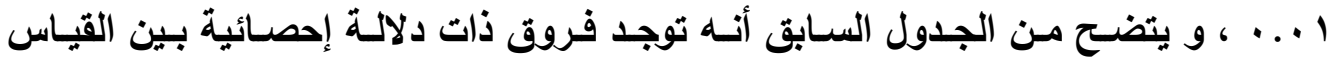
القبلى و البعدى للمجموعة التجريبية فى متوسط بعد المرونة العقلية المعرفية لصالح القياس

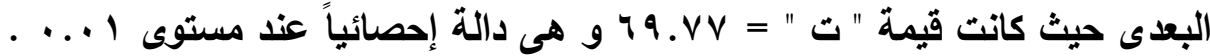
ويتضح من الجدول السابق أنه توجد فروق ذات دلالة إحصائية بين القياس القبلى

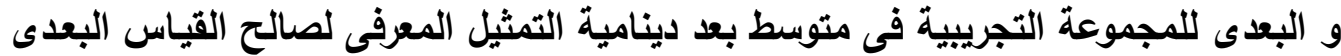

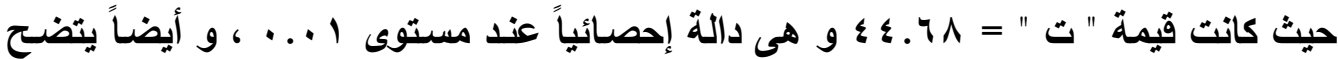

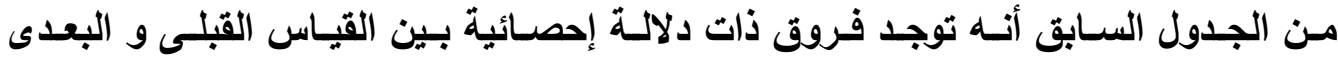
للمجموعة التجريبية فى متوسط الارجة الكلية لصالح القياس البعدى حيث كانت قيمة " ت ت "

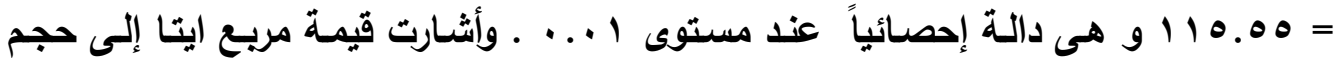

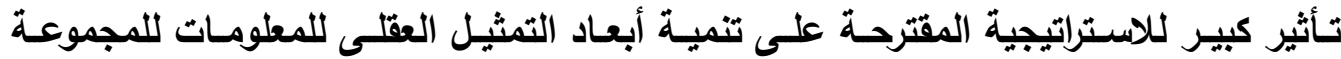
التجريبية بعد دراسة الوحدة. ويمكن توضيح هذه النتيجة من خلال الثكل التالى:

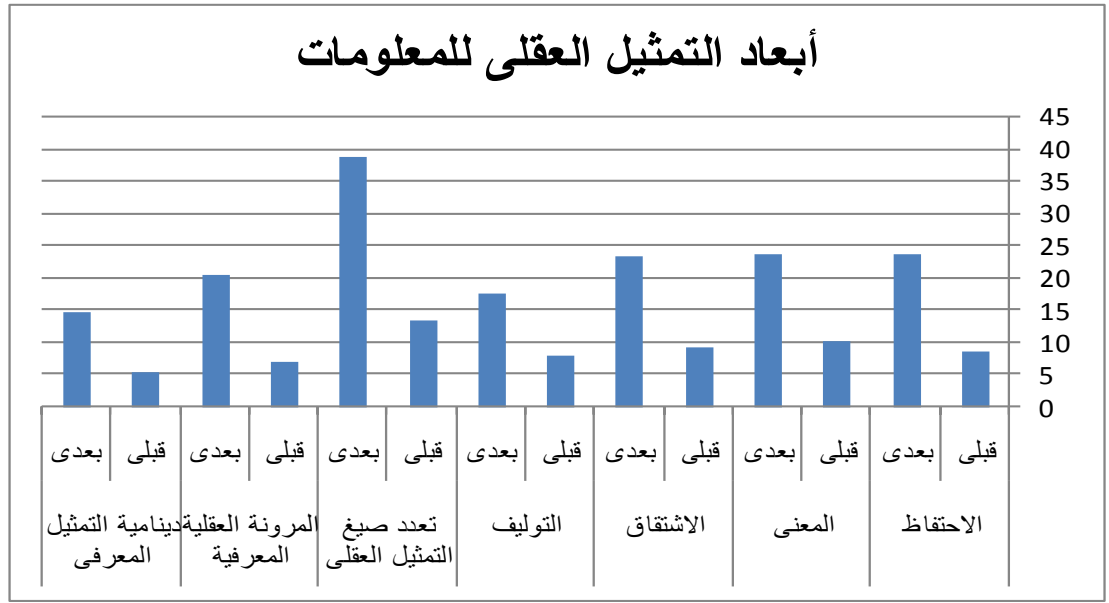

شكل( ؛ ) يوضح المتوسطات الحسابية لمقياس التمثيل العقلى للمعلومات في القياسين القبلى والبعدى للمجموعة التجريبية 
تقنسير النتشائج:

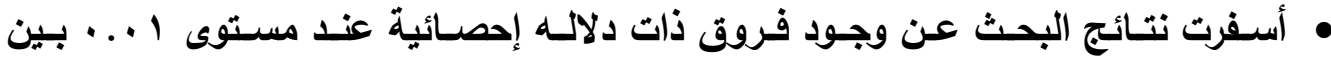
متوسطى درجات طلاب المجموعتين التجريبية والضـابطة في التطبيق البعدي فى اختبار مهارات التحقيق الجغرافى والدرجة الكلية لصالح المجموعة التجريبية، ويرجع ذلك لتأثير استخدام الاسـتراتيجية المقترحة القائمسة على الدمج بين دورة التعلم السباعية ومحطات التعلم فى تدريس الوحدة المعاد صياغتها، ومـا اشتملت عليه الاستراتيجية من مجموعة من الخطوات والمراحل أدت في النهاية إلى زيادة تنمية مهارات التحقيق الجغرافى للطلاب، بينمـا المجموعة الضـابطة درست الوحدة بالطريقة المعتادة. فكان للاستراتيجية المقترحة تأثير إيجابي على طلاب المجموعة التجريبية. كما أسفرت عن وجود فروق ذات دلاله إحصائية عند مستوى 1 . . •بين متوسطي درجات طلاب المجموعـة التجريبية فى التطبيقين القبلى والبعدى فـى اختبـار مهارات التحقيق الجغرافى ككل وفى كل مهارة على حده وذلك لصـالح التطبيق البعدى، ويرجـع ذلك إلى استخدام الاستراتيجة المقترحة القائمـة على الـمـج بين دور التعلم السباعية ومحطات التعلم، بالإضافة إلى ما اشتملت عليه الوحدة المعاد صياغتها من صور وخرائط وأثكال توضيحية ورسوم وفيديو ومواقع اليكترونية تم الاستعانة بها في تدريس الوحدة الأمر الأى ساهم في نشاط الطلاب وتفاعلهم وتنمية مهارات التحقيق الجغرافى. كنلك مـا احتوت علية الوحدة من العديد من الأنثطة التعليمية داخل الفصل وخارجة سـاعدات الطلاب على تنمية مهارات التحقيق الجغرافى لايهم بشكل عام وكل مهارة من المهارات على حدة، وذلك مـن حيـث تحديـد الهـف مـن التحقيـق وتمثيـل المعلومـات الجغرافيـة وجمـع المعلومـات والتوصل إلى استتتاجات وتعميمـات، وأيضـا كـان لدليل المعلم الذي تـم استخدامه أثناء التدريس بالغ الأثر في تحقيق أهداف الدراسـة الأمر الذى أدى إلى ظهور هذه الفروق بين التطبيقين القبلى والبعدى لاختبار مهارات التحقيق الجغرافى.

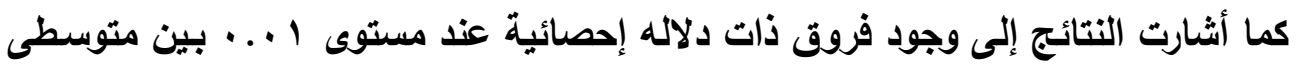
درجات طلاب المجموعتين التجريبية والضـابطة في التطبيق البعدي فى مقيـاس التمثيل

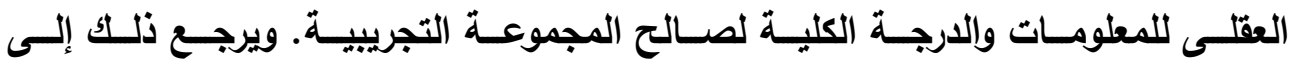
الاستراتيجية المقترحة التي تقوم على تنويع استخدام التمثيلات المعرفية مثل(رسوم بيانية 
وخرائط- - رسوم توضيحية- خرائط معرفية) لعرض المحتوى العلمى للطلاب، وكذلك تنويع الخبرات التعليمية وتلبية أنماط التعلم المختلفة لديهم. كما كان للمعلم دور هامـاً في زيادة نشاط الطلاب وقيامهم بالأنشطة المختلفة التي تثجيعهم على تمثيل المعلومـات التي تم مشـاهلاتها وجمعها في أشكال وخرائط معرفية وجداول. ولكن طلاب المجموعة الضـابطة الأين درسوا الوحدة بالطريقة المعتادة لم يظهر تأثير في التمثيل العقلى للمعلومات لايهم.

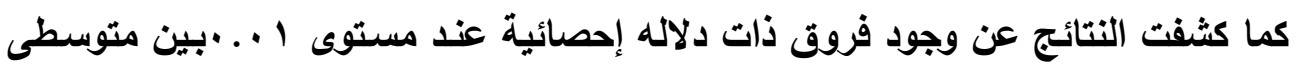
درجات طلاب المجموعة التجريبية في التطبيقين القبلي والبعدي لمقياس التمثيل العقلى للمعلومـات ككل وفى كل بعد على حده وذلك لصـالح القياس البعدى. ويرجيع ذلك تقديم

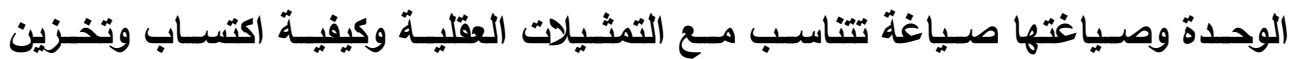
المعلومـات في الـدماغ. بالإضـافة إلى تقديم المعلومـات بطريقة منظمـة ومشـوقة تجذب

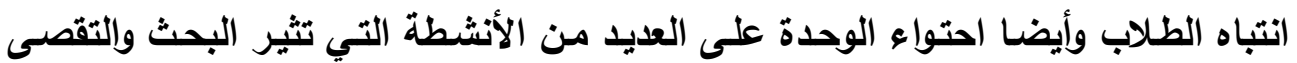
والاكتشـاف لــى الطـلاب سـاعدهم في اكتسـاب المعلومـات بأنفسـهم وتخزينهـا بـالطريق المناسبة لهم. توصبيات البحث: يوصى البحث بـ • الاهتمام بلمهج العديد من الاستراتيجيات التعليمية مـع بعضها البعض، والخروج بخطوات جديدة تجمع مميزات هذه الاستراتيجيات ليكون تأثثرها كبير على الطلاب. • تنويع طرق وأساليب التدريس لتشمل عمليات قرائية وسمعية ويصرية وإلكترونية. • ضرورة عقد ورش ودورات لتدريب المعلمين على كيفية التوليف واللدمج بين الاستراتيجيات التدريسية وكيفية تطبيقها داخل الفصول وخاصـة تلك الاستراتيجيات القائمسة على البنائية والخبرات السابقة للطلاب مثل المحطات العلمية ودورة التعلم السباعية. • التركيز على تنميـة مهارات الطـلاب الجغرافيـة عامـة ومهارات التحقيق الجغرافى خاصـة، لمواجهة المجتمع بكل تغيراته ومستجداته ومشكلاته. • تقديم المعلومـات للطـلاب بمـا يتناسب مـع التمثيلات العقليـة لـديهم سـواء في اكتسـاب المعلومات والاحتفاظ بها أو توظيفها. • دمــج مهـارات التحقيـق الجغرافـى في منــاهج ومقـررات الجغرافيـا في المراحلـل الدراسـية المختلفة. 
• البحث عن طرق وأساليب جديدة يمكن تقديم المحتوى العلمى للطلاب من خلالها لمواجهة متطلبات القرن الحادى والعشرين.

\section{مقترحات البحث:}

فى ضوء نتائج البحث، يقترح إجراء الدراسات التالية:

• فاعلية استخدام المحطات العلمية في تنمية مهارات التفكير الجغرافى لطلاب المرحلة الإعدادية.

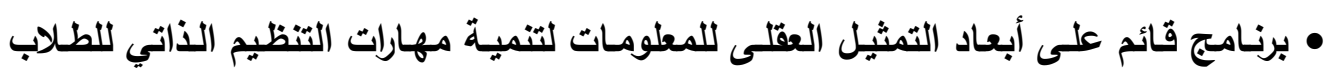
المعلمين بكلية التربية شعبة الجغرافيا. • وحدة مقترحسة في الجغرافيـا قائمسة على دورة التعلم السباعية لتنميـة التفكير التسـيقى لتئى لطلاب المرحلة الثانوية. • تقويم منـاهج الدراسـات الاجتماعيـة في المرحلـة الابتدائيـة فـي ضـوء مهارات التحقيـق الجغرافى. • برنـامج تـدريبى لمعلى الجغرافيـا قـائم على دورة التعلم السباعية لتنميـة مهـارات الأداء التدريسى. 


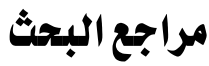

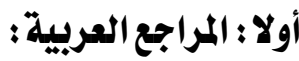

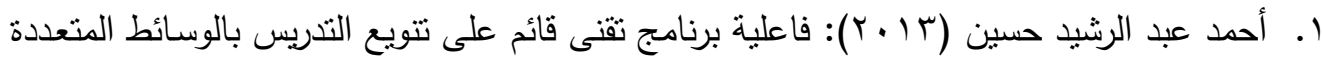

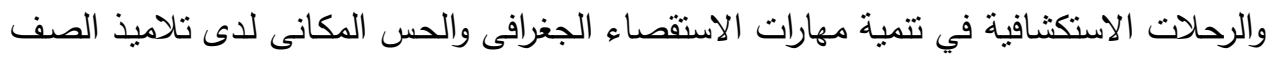

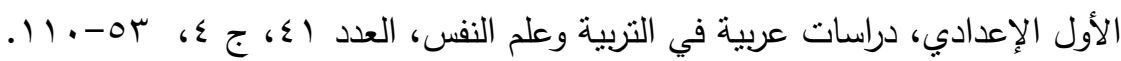

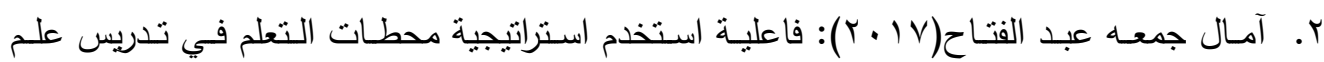
الاجتماع على تتمية التفكير الاستدلالى والتنسامح الاجتماعى لاعى طلاب المرحلة الثانوية، مجلة

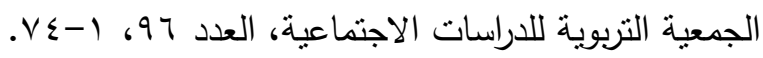

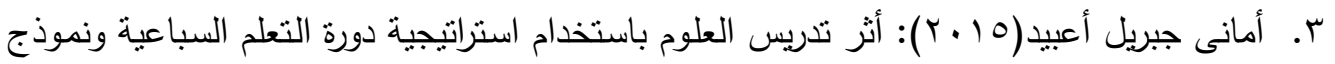

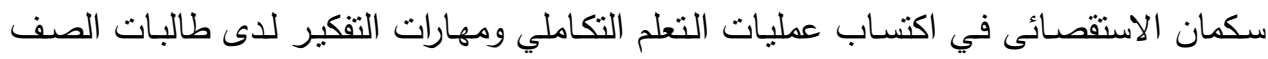
الثامن الأساسـى في الأردن، رسـالة دكتوراه، جامعـة العلوم الإسـلامية، كليـة الدراسـات العليـا،

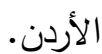

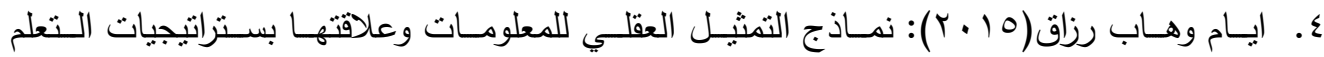

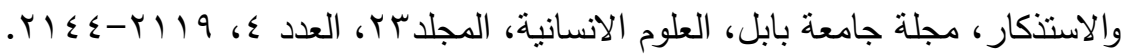

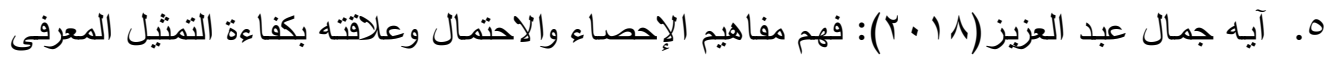
للمعلومات والتفكير التجريدى لدى طلبة الصف الحادى عشر ، رسالة ماجستير، جامعة القدس.

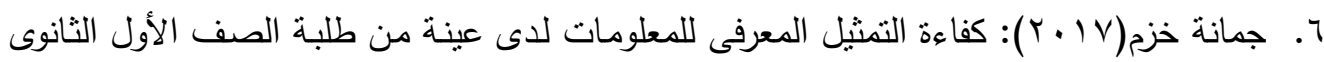

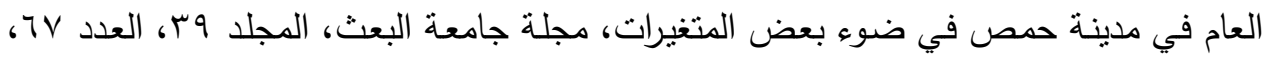
$.1 Y \leq-9 V$

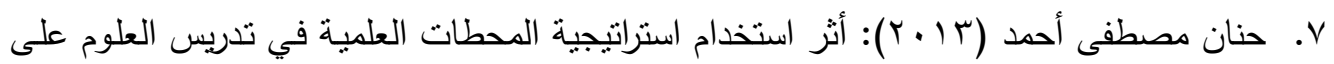
التحصيل المعرفي وتتمية عمليات العلم و التقكير الإبداعي والدافعية نحو تعلم العلوم لدى تلاميذ الديذ

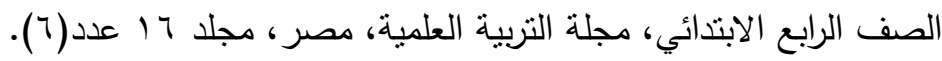

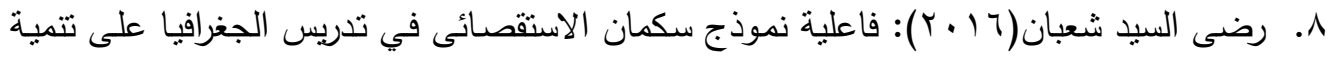

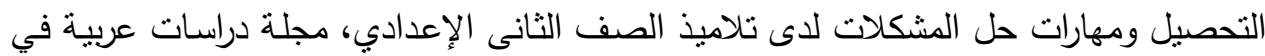

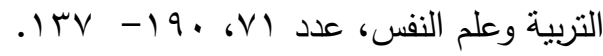

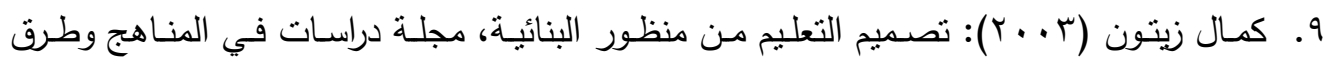

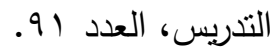




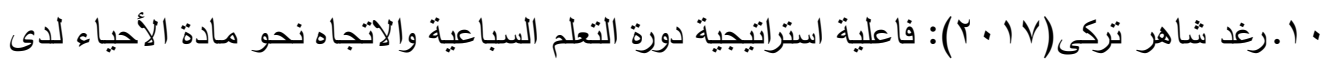

طلاب الصف العاشر الأساسى في الأردن، مجلة كلية التربية، جامعة الأزهر، العدد ع V أ.

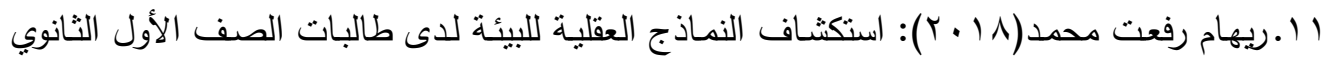
وتصـور مقترح لتطويرها فى ضـوء استراتيجية محطات التعلم، مجلة الجمعيـة التربويـة للدراسـات

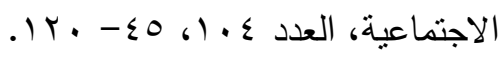

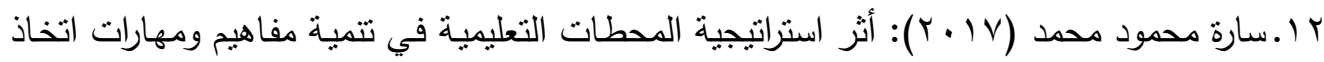
القرار في التكنولوجيـا لـدى طالبـات الصـف السـادس الأساسـى، رسـالة ماجستير، كليـة التربيـة

بالجامعة الاسلامية بغزة.

با ـ سالم الغرايبة ومنى عبد الله(1 ـ r): كفاءة التمثيل المعرفي وعلاقتها بمهارة حل المشكلات لدى

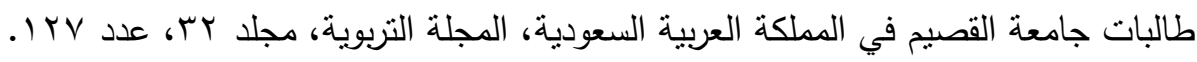
ع ا ـ سـاهر ماجد شـدة (0 1 ب): أثر توظيف استراتيجيتي المحطات العلميـة والخرائط الذهنيـة في تتميـة المفـاهيم الفيزيائيـة ومهـارات التفكيـر البصـري في مـادة العلـوم لـدى طلبـة الصـف الرابـع الأساسي بغزة، رسالة ماجستير غير منشورة، الجامعة الاسلامية، كلية التربية، غزة، فلسطين. ه ـ سعدية شكري على(T ( ـ (Y): فاعلية برنامج مقترح في علم النفس قائم على الدمج بين دورة التعلم السباعية والإعجـاز العلمي في القرآن والسنة في تتميـة مهارات التفكير التأملي وتحسين جودة الحياة لدى طلاب المرحلة الثانويـة الأزهرية، مجلة الجمعية التربوية للاراسـات الاجتماعية، العدد

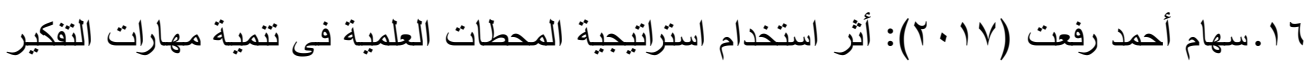
الناقد وبعض عادات العقل فى مادة الاقتصاد المنزلى لدى تلميذات المرحلة الإعدادية ، مجلة بحوث عربية في مجالات التربية النوعية - رابطة التربوبين العرب، مصر، العدد ^ ، اسب-

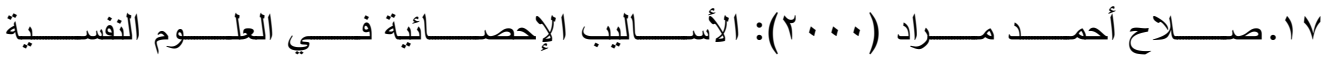
والتربوية والاجتماعية، القاهرة، لأنجلو المصرية.

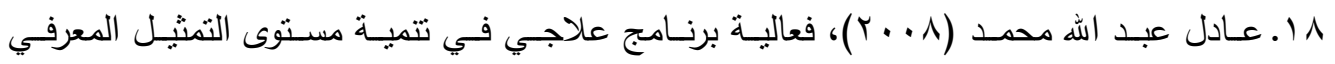
للمعلومات لاى تلاميذ الصف السادس الابتدائي ذوي صعوبات التعلم في الفهم القرائي، ندوة علم النفس وقضايا التتمية الفردية والاجتماعية، جامعة الملك سعود. 9 1 ـ عاصم محمد إبراهيم (1) ( † ): فاعلية تدريس مقرر الأحياء باستخدام استراتيجية محطات التعلم في تتمية اليقظة الذهنية والاستيعاب المفاهيمي لدى طلاب الصف الأول الثانوي، مجلة الدراسات التربوية والنفسية، جامعة السلطان قابوس، مجلد ا العدد ب ابريل. 


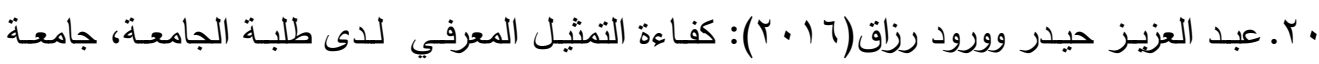

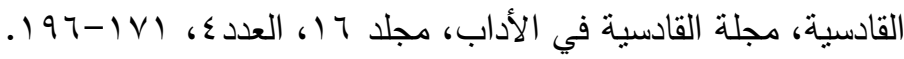
ا ( . على عبد الكريم ونافز أحمد(9 . . Y): أثز استخدام طريقة التعلم بالاستقصاء في تحصبل طلبة كلية العلوم التربويـة (الأونروا) في مساق جغرافيـة الوطن العربي واتجاهاتهم نحوها، مجلة اتحاد الجامعات العربية، العدد سه ، r r. علي صكر جابر (9 . . r): القدرة على اتخاذ القرار على وفق كفاءة التمثيل المعرفي للمعلومات لدى طلبة الجامعة، مجلة القادسية للعلوم الإنسانية، العدد (ع) المجلد (Y ()، كلية الآداب، جامعة

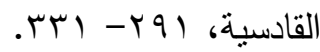

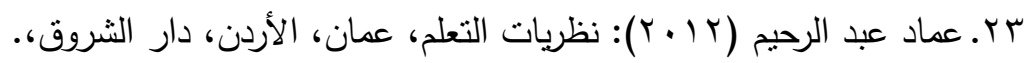

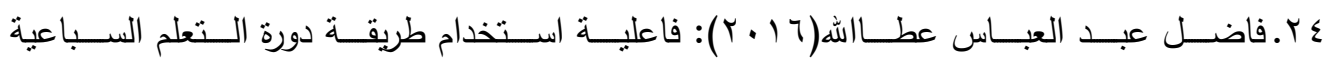
المعدلة(E's7)على التحصيل لدى طلاب المرحلة المتوسطة في مادة الرياضيات، مجلة الكلية

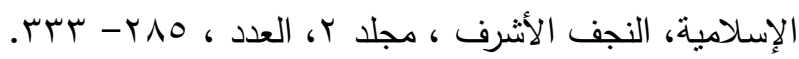
ه ـ فتحى مصطفى الزيات(9 991 ( ): الأسس البيولوجية والنفسية للنشاط العقلى المعرفى، القاهرة ، دار الجامعات للنشر .

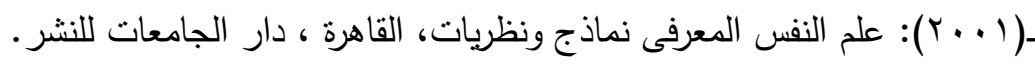
ry

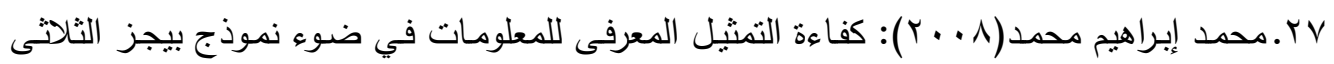
لدى عينة من طلاب كلية التزبية بالمنيا، رسالة ماجستير جامعة المنيا.

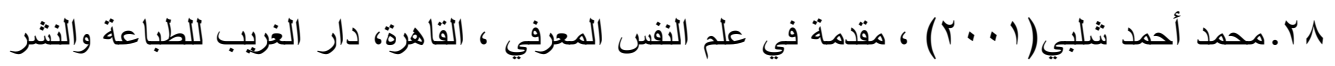

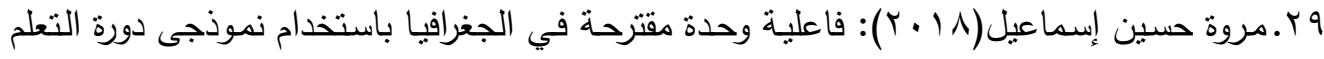
السباعية والفورمات في تتمية مفاهيم الأمن المائى وبعض القيم البيئية لدى تلاميذ الصف الثانى

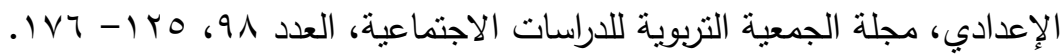
• r. معزز محمد سـليم(Y ( • Y): أثنر استخدام استراتيجية الخطوات السبع في تتميـة بعض مهارات التفكير الرياضسي في جانبي الدماغ لدى طالبات الصف الثامن الأساسي بغزة، رسالة ماجستير غير منشورة، كلية التربية، الجامعة الإسلامية، غزة.

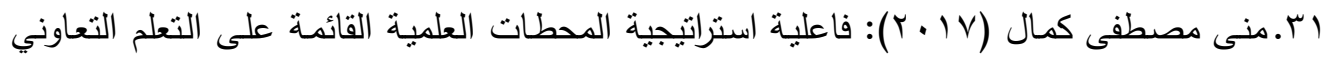
في تتمية التحصيل العلمي والأداء التدربسي لدى طلاب كلية التربية شعبة الفيزباء والكيمباء، مجلة التربية العلمية، مجلد ·r العدد(r). 


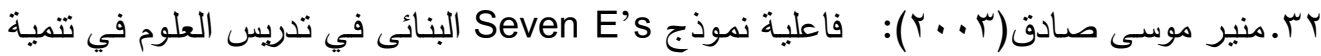
التحصيل وبعض مهارات عمليات العلم لدى طلبة الصف الثانى الإعدادي بسلطنة عمان، مجلة التربية العلمية، مجلد T، العدد r.

بr.نجـاء مجد مجد النحاس(T ( • ץ): دليل مرجعى قائم على المعايير المهنية لتدريس الجغرافيا المدرسية لتتميـة مهارات التحقيق الجغرافى بالعمل الميدانى لدى معلمى الجغرافيـا، مجلـة كليـة

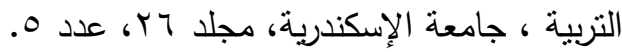

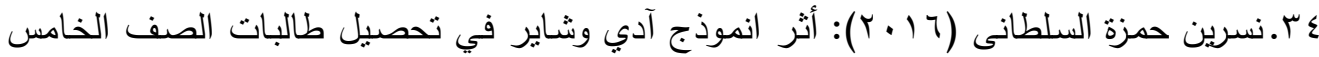
العلمي في مادة الاحياء والتمثيل المعرفي لديهن، مجلة جامعة بابل، العلوم الانسانية، المجلدا،

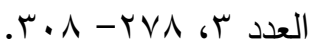

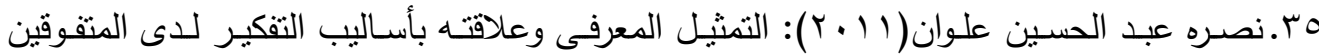
دراسياً في المرحلة الإعدادية، رسالة ماجستير ، كلية التربية الأساسية، جامعة ديالى، العراق.

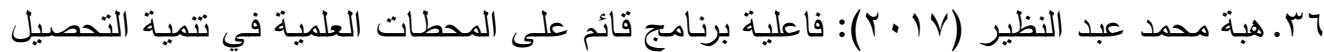
ومهارات القرن الحادي والعشرين لدى تلاميذ المرحلة الابتدائية المتفوقين عقليًا ذوي صعوبات تعلم الرياضيات، مجلة تربويات الرياضيات، · · ( ( ).

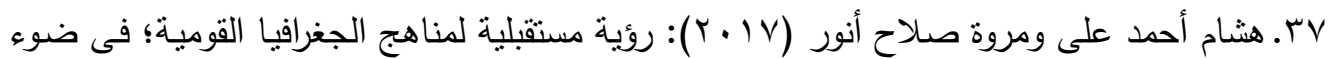
المعايير العالمية (C3, GFL2nd, ACARA)، مجلة الجمعية التربوية للاراسات الاجتماعية،

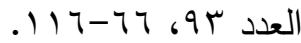

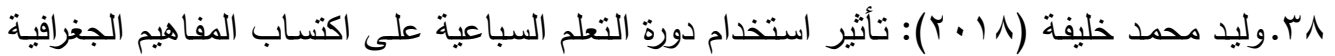
وبعض مهارات التفكير المنظومى لاى تلاميذ الصف السادس الابتدائي، مجلة الجمعية التربوية

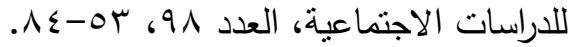

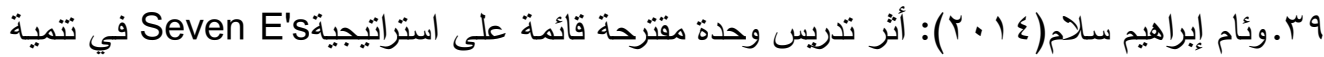

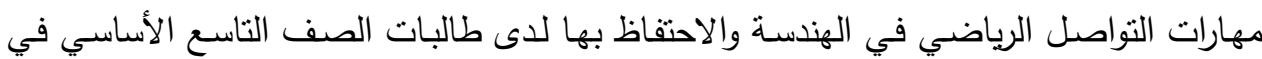
غزة، رسالة ماجستير، كلية التربية، جامعة الأزهر ، غزة.

\section{ثانياً: المراجع الأحنبية:}

40. Aditomo, A.,Goodyeara,P.,Bliuc,A,\& Ellis,R.(2011). Inquiry- Based Learning in Higher Education: Principal Forms Educational Objectives, and Disciplinary Variations. Studies in Higher Education.38 (9).

41. Aijallad, Z. Ali, R. (2018). The Influence of Using the (7Es) Learning Cycle Strategy on Achievement of Eighth Grade Students in Islamic Jurisprudence Unit and Developing their Deductive Thinking Skills.," International Journal for Research in Education: Vol. 42 : Iss. 
42. AQA.(2018). Geography fieldwork investigation, Available at https://www.aqa.org.uk/subjects/geography/as-and-a-level/geography-

7036/subject-content/geography-fieldwork-investigation.

43. Aqel, M. \& Haboush, S. (2017). The Impact of Learning Stations Strategy on Developing Technology Concepts among Sixth Grade Female Students. Learning, International Journal of Academic Research in Progressive Education and Development, 6(1),64-77

44. Australian Curriculum Assessment and Reporting Authority (acara) (2013). Australian Curriculum: Geography. Available at www.australiancurriculum.edu.au/geography/rationale.

45. Balta, N. \& Sarac, H. (2016). The Effect of 7E Learning Cycle on Learning in Science Teaching: A meta-Analysis Study. European Journal of Educational Research, 5(2), 61-72.

46. Bulunuz ,N. and Olga, J.(2010). The Effects of Hands on Learning Science Stations on Building American Elementary Teachers Understanding about Earth and Space Science Concepts, Journal of Mathematics Science and Technology Education ,6(2),85-99.

47. Chien, Chin-Wen(2017).Undergraduates' Implementations of Learning Stations as Their Service Learning among Elementary School Students, Education 3-13, 45(2), 209-226

48. Collins, t . Cooper, v. Kerawalla, L. Norman, S \& Rudd, S.( 2016).Geographical investigations A level geography, Available at www.geography-fieldwork.org.

49. Dangwal, R., Sharma, K., \& Hazarika, S. (2014). Hole-in-the-wall learning stations and academic performance among rural children in India. Journal for Multicultural Education, 8(1), 31-53

50. David, R.(2013). Station Learning: Does it Clarify Misconceptions on Climate Change and Increase Academic Achievement through Motivation in Science Education, ME.D thesis, he Faculty of the Patton College of Education and Human Services, Ohio University.

51. Davies, B.(2018). A-Level Geography Fieldwork Investigation, Available at http://www.antarcticglaciers.org/students-3/geography-a-level-2/a-levelgeography-fieldwork-investigation/.

52. Duchovicova, J. \& Kozarova, N. (2017): Mental representation of learning content and learning style, Slavonic Pedagogical Studies Journal, Vol. 6, No. 1, Slovakia.

53. ESRI. (2003).Geographic Inquiry: Thinking Geographically ESRI Schools and Libraries Program, Available at www.esri.com/k-12.

54. Guardian,M .(2015). Module 4 Learning Stations and Digital Libraries, Professional Development Course Module 4 Presentation, Available at: http://www.ict4red.co.za/download/module-4-mindmapping/( March). 
55. Gurbuz, F.Mitturgut, R .(2012).The effect of 7 E learning model of academic achievement and retention of 6 the grade science and technology course students in the unit "Electricity in our life". Vol. (10), Issue (4), Ataturk University, Erzurum- Turkey.

56. Jones, D.(2007). The Station Approach: How to Teach With Limited Resources, National Science Teachers Association, From : www.nsta.org/main/news/.../science scope.php.

57. Khashan, K. (2016). The Effectiveness of Using the 7E's Learning Cycle Strategy on the Immediate and Delayed Mathematics Achievement and the Longitudinal Impact of Learning among Preparatory Year Students at King Saud University (KSU). Journal of Education and Practice , 7(36), 40-52.

58. Lim EN Qi, (2018), The Role of Geographical Investigations In Developing Students' Cognitive Thinking, National Institute of Education, HSSE Online ,7(1) Available at https://www.hsseonline.edu.sg/journal/volume-7-issue-1-2018/rolegeographical-investigations-developing-students\%E2\%80\%99cognitive/page/0/2.

59. McKnight, A. (2012): Enhancing students' scientific and quantitative illiteracies through an inquiry-based learning project on climate change .Journal of the Scholarship of Teaching and Learning, 12 (4), 86-102.

60. Mehmet,U .(2011) The Level of Realizing Geographical Skills in Geography Lessons, Educational Sciences: Theory \& Practice - 11(4).

61. Ocak, G. (2010). The Effect of Learning Stations on the Level of Academic Success and Retention of Elementary School Students, The New Educational Review, 21(2):146-156.

62. Opas, N. et. al (2009): Effects of environmental education by using the 7's - learning cycle with multiple intelligences and the teacher's handbook approaches on learning achievement, critical thinking and integrated science process skills of high school, (Grade 10), Pakistan Journal of Social Sciences, (6), Issue (5).

63. Sirbunnam, R. Tayraukham,S (2009). Effects of 7' E, KWL and conventional in struction on analytical thinking learning achievement and attitudes towards chemistry learning, Journal of Social Sciences, (4).

64. Suprabha, K., \& Subramonian, G. (2014). How Does Station Teaching Effect Language Learning?. Journal on English Language Teaching, JulSep , 4(3), 21-25.

65. Wheeler, A. Young, C. Oliver,K \& . Smith,J. (2011). Study skills enhancement through geography and environmental fieldwork, Planet, 24:1, 14-20, DOI: 10.11120/plan.2011.00240014 